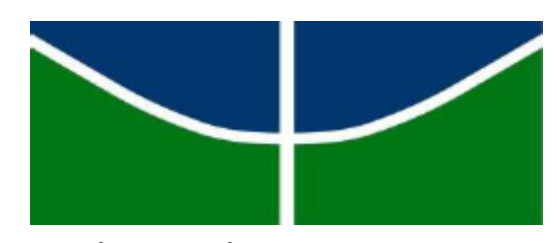

\author{
Universidade de Brasília \\ Instituto de Ciências Biológicas \\ Programa de Pós-Graduação em Biologia Molecular
}

ANTICORPOS IgG MURINOS DE DIFERENTES ISOTIPOS

E REGIÃO VARIÁVEL IDÊNTICA SE LIGAM DE FORMA DIFERENTE À CÁPSULA DE CRYPTOCOCCUS NEOFORMANS E A RECEPTORES FC-GAMA

Autora: Diane Sthefany Lima de Oliveira Orientadora: Dra. Maria Sueli Soares Felipe 


\section{DIANE STHEFANY LIMA DE OLIVEIRA}

\section{ANTICORPOS IgG MURINOS DE DIFERENTES ISOTIPOS E REGIÃO VARIÁVEL IDÊNTICA SE LIGAM DE FORMA DIFERENTE À CÁPSULA DE CRYPTOCOCCUS NEOFORMANS E A RECEPTORES FC-GAMA}

Dissertação apresentada ao Programa de PósGraduação em Biologia Molecular da Universidade de Brasília como requisito parcial para a obtenção do título de mestre em Biologia Molecular.

Orientadora: Dra. Maria Sueli Soares Felipe

\section{Brasília}


Dissertação de autoria de Diane Sthefany Lima de Oliveira, intitulada “ANTICORPOS IgG MURINOS DE DIFERENTES ISOTIPOS E REGIÃO VARIÁVEL IDÊNTICA SE LIGAM DE FORMA DIFERENTE À CÁPSULA DE CRYPTOCOCCUS NEOFORMANS E A RECEPTORES FC-GAMA", apresentada como requisito parcial para a obtenção do grau de Mestre em Biologia Molecular da Universidade de Brasíliaem 22/02/2016,sido defendida e aprovada pela banca examinadora abaixo assinada:

Prof $^{a}$. Dra. Maria Sueli Soares Felipe (Orientadora)

Programa de Pós-Graduação em Biologia Molecular - UnB

Prof $^{a}$ Dra. Andrea Queiroz Maranhão (Membro interno)

Programa de Pós-Graduação em Biologia Molecular - UnB

Prof. Dr. Márcio Lourenço Rodrigues (Membro externo)

Fundação Oswaldo Cruz - Fiocruz

Dra. Galina Gulis (Suplente)

Universidade Católica de Brasília - UCB

Brasília 


\section{AGRADECIMENTOS}

Esse trabalho não teria sido possível se Deus não estivesse me fortalecido diariamente com o suporte de pessoas essenciais em minha carreira e vida pessoal.

Lucas você foi incrível, quando caminhou lado a lado comigo nesses dois anos intensos e surpreendentes. Além de um namorado, pude encontrar em você um grande amigo e companheiro de trabalho. Ainda fui presenteada com sua família linda que me apoiou nesse período de transformação. Especialmente Jane, obrigada pelo carinho, compreensão, comidinhas e amizade. Agradeço também à minha família por sempre terem investido e acreditado em mim. Principalmente as duas flores da minha vida, Mãe e Vó, que se esforçaram muito para construir meu carácter e foram em momentos difíceis minha inspiração e força.

Agradeço ao professor André que apostou em mim desde o início e me proporcionou grandes oportunidades. Você me fez acreditar que sou capaz de ir muito além. Obrigada por sua fé em mim, você já é um grande amigo. Assim também vai meu muito obrigado à Paty que é uma pessoa linda e que vem me apoiando nessa jornada. Agradeço também a professora Sueli pelos ensinamentos e suporte.

Dra.Verenice, você é maravilhosa e sem você nada disso seria possível. Obrigada pela ótima companhia, por compartilhar os momentos de insanidade e por ser amiga, além de uma grande profissional. Agradeço também ao pessoal da Karan Technologies, Ananésia e Alessandra, que também fizeram parte deste trabalho em equipe.

Aos amigos de infância e de jornada, obrigada pela confiança e parceria. Vocês são demais!

Aqui também vão meus agradecimentos à CAPES, e ao programa de Biologia molecular pelo apoio financeiro e por viabilizarem a formação de pesquisadores no Brasil. 


\section{RESUMO}

É estimado que ocorram 625 mil mortes por ano no mundo por meningite criptococócica, a maioria indivíduos infectados por HIV. Cryptococcus neoformansé o responsável pela maioria dessas mortes. Visto que tratamento da criptococose com antifúngicos convencionais tem se mostrado menos eficaz do que o ideal, anticorpos monoclonais contra a cápsula do fungo foram desenvolvidos nas últimas três décadas com objetivo de criar novas ferramentas terapêuticas. No entanto, ao tratar camundongos com diferentes isotipos de anticorpos, diferentes respostas protetoras foram observadas. Por exemplo, tratamento com anticorpo monoclonal 3E5 IgG1 de camundongos infectados com $C$. neoformans resultou em aumento da sobrevida, enquanto os animais tratados com anticorpo de região variável idêntica mas com isotipo IgG3 apresentaram resposta agravante de doença. Ensaios de ligação ao antígeno por imunofluorescência mostraram que os padrões de ligação destes dois isotipos de 3E5 à cápsula são diferentes, o que pôs em questão o conceito clássico de que a ligação ao antígeno é exclusivamente determinada pelas porções variáveis do anticorpo. Além destas diferenças de ligação ao antígeno, diversos estudos publicados a partir da década de 1980 sugerem que o isotipo IgG3 interage com um receptor de Fc na superfície de macrófagos que é diferente dos que se ligam aos outros isotipos, o que também poderia explicar diferenças na proteção conferida pelos anticorpos 3E5 de diferentes isotipos de IgG. Tendo em vista a importância terapêutica de se conhecer adequadamente os mecanismos pelos quais um mesmo anticorpo IgG pode ser protetor ou não, dependendo de seu isotipo, este trabalho teve por objetivos produzir novos anticorpos monoclonais recombinantes, avaliar seu padrão de ligação ao antígeno e sua capacidade de mediar fagocitose por receptores de Fc. Dois pares de anticorpos IgG1 e IgG3 foram produzidos por meio de expressão heteróloga em células de mamífero. $\mathrm{O}$ primeiro par deriva do anticorpo monoclonal $2 \mathrm{H} 1$, anticorpo contra a cápsula de $C$. neoformans cuja estrutura cristalográfica já foi resolvida. O segundo par deriva do anticorpo 4-4-20, que reconheceo hapteno FITC, e foi gerado a fim de avaliar se a resposta efetora mediada por receptores é exclusiva de anticorpos contra C. neoformans. Osdomínios variáveis das cadeias pesada e leve dos anticorpos foram gerados por síntese química e clonadas em vetores para expressão deIgG1 e IgG3 murinos, que foram então transfectados em células CHO e NSO. As condições de transfecção e purificação foram otimizadas e resultaram na produção de lotes dos anticorpos suficientes para testes funcionais. A ligação dos anticorpos a células de $C$. neoformansfoi testada por imunofluorescência indireta e sua capacidade de mediar fagocitose testada com macrófagos J774 e células CHO-K1. Os anticorpos 2H1 apresentaram padrão de fluorescência semelhante aos de 3E5, com padrão de ligação a células de $C$. neoformans anular para IgG1 e puntiforme para IgG3. Os dois isotipos de anticorpos 2H1 e 4-4-20 foram também funcionais em testes de fagocitose por macrófagos. Os anticorpos de isotipo IgG1 mostraram dependência exclusiva dos receptores Fcy, enquanto que 2H1-IgG3 foi capaz de mediar fagocitose mesmo com esses receptores bloqueados. Portanto, os anticorpos recombinantes produzidos foram funcionais e permitiram a realização de experimentos importantes, que evidenciaram que a cadeia pesada pode alterar a ligação do anticorpo ao antígeno e comprovaram que o isotipo $\mathrm{IgG} 3$ pode mediar fagocitose por meio de um receptor desconhecido.

Palavras-chave: Cryptococcus neoformans, anticorpos recombinantes $\operatorname{IgG}$ murino, mecanismo molecular da resposta protetora. 


\begin{abstract}
It is estimated there are 625,000 deaths worldwide per year caused by cryptococcal meningitis, the most affects people infected by HIV. Cryptococcus neoformans is responsible for the majority of these deaths. Since treatment of cryptococcosis using conventional antifungal has been less effective than ideal, monoclonal antibodies against fungus capsule were developed in the last three decades in order to create new therapeutic tools. However, treating mice with different isotypes of antibody were observed different protective responses. For example, treatment of $C$. neoformans infected mice with monoclonal antibody 3E5 IgG1 resulted in increased survival, whereas the disease was aggravated in animals treated with IgG3 antibody of identical variable region. Immunofluorescence assay showed that the binding patterns of these two 3E5 isotypes are diferentes to the capsule, which became questionable the classical concept of the antigen binding that defines it is exclusively determined by antibody variable region. In addition to these antigen binding differences, many studies published in 1980s suggest that the IgG3 isotype interacts with an Fc receptor on the surface of macrophages differently from other isotypes, which could also explain differences in protection provided by the 3E5 antibodies of different IgG isotypes. Considering the therapeutic importance of properly knowing the mechanisms by which the same IgG antibody may be protective or not, depending on their isotype, this study aimed to produce new recombinant monoclonal antibodies, assessing its binding standard antigen and its ability to mediate phagocytosis by Fc receptors. Two pairs of IgG1 and IgG3 antibodies were produced by heterologous expression in mammalian cells. The first pair was derived from monoclonal antibody $2 \mathrm{H} 1$, the antibody against $C$. neoformans capsule whose crystal structure has been resolved. The second pair was derived from the 4-4-20 antibody that recognizes the hapten FITC and was generated to evaluate whether receptor-mediated effector response is unique to antibodies against $C$. neoformans. The heavy and light chains variable domains of the antibodies were generated by chemical synthesis and cloned into expression vectors for IgG1 and IgG3 murine, then they were transfected into CHO and NSO cells. The transfection and purification conditions were optimized and led to the batch production of antibodies until it was sufficient for functional testing. The binding of the antibodies to $C$. neoformans cells was tested by indirect immunofluorescence and its ability to mediate phagocytosis by $\mathrm{J} 774$ macrophages and CHO-K1 cells. The $2 \mathrm{H} 1$ antibody showed binding pattern similar to that for 3E5, showing annular and punctate pattern for IgG1 and IgG3 respectively. Both $2 \mathrm{H} 1$ and 4-4-20 antibodies were also functional on phagocytosis assay by macrophages. The IgG1 isotype showed exclusive dependence on Fc $\gamma$ receptor, whereas $2 \mathrm{H} 1$ IgG3 was able to mediate phagocytosis even when this receptor was blocked. Therefore, the produced recombinant antibodies were functional and allowed the attainment of important experiments which showed that heavy chain can alter antibody binding to the antigen and that IgG3 isotype can mediate phagocytosis through an unknown receptor.
\end{abstract}

Key-words: Cryptococcus neoformans, recombinant mouse $\mathrm{IgG}$ antibodies, molecular mechanism of protective response. 


\section{LISTA DE ILUSTRAÇÕES}

Figura 1 - Distribuição de meningite criptocócica no mundo e na África Subsaariana. ......... 14 Figura 2 - Distribuição global dos principais tipos moleculares do complexo C.

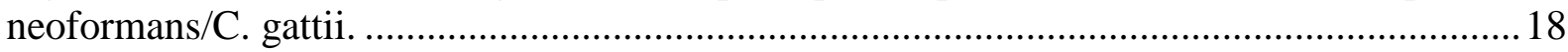
Figura 3 - Correlação taxonômica, molecular, epidemiológica e clínica entre espécies do

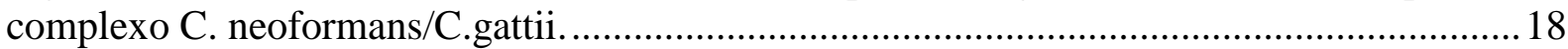
Figura 4 - Mecanismo de disseminação de C. neoformans pela barreira hemato-encefálica. . 20 Figura 5 - Estrutura polissacarídica da cápsula de C. neoformans. ....................................... 21

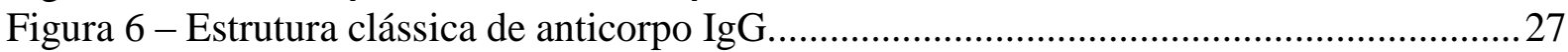
Figura 7 - Padrão de imunofluorescência anular e puntiforme dependente de $\mathrm{CH}$................29 Figura 8 - Sequência de genes 2H1 e 4-4-20 VH e VL............................................................ 34 Figura 9 - Mapa do vetor pUC57 (GenScript) carreador dos insertos 2H1 e 4-4-20 VH/VL . 35 Figura 10 - Mapa do vetor de expressão pFUSE-CHIg-mG1 (Invivogen) para clonagem dos insertos $\mathrm{VH}$.

Figura 11 - Mapa do vetor de expressão pFUSE-CHIg-mG3 (Invivogen) para clonagem dos insertos $\mathrm{VH}$.

Figura 12 - Mapa do vetor de expressão pFUSE2-CLIg-mk (Invivogen) para clonagem dos

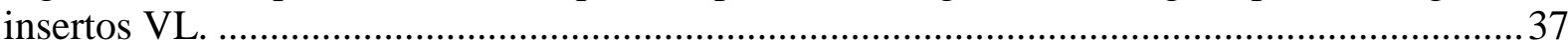

Figura 13 - Substituição de fragmentos CH1 e dobradiça entre 2H1-IgG1 e 2H1-IgG3. ....... 45 Figura 14 - Clonagem de 2H1 e 4-4-20 em vetores pFUSE visualizados em gel de agarose a $1 \%$

Figura 15 - DO por ELISA de clones produtores de 2H1-IgG3 selecionados por diluição limitante.

Figura 16 - DO por ELISA de clones produtores de 4-4-20-IgG3 selecionados por diluição limitante.

Figura 17 - Concentração por ELISA $(\mu \mathrm{g} / \mathrm{mL})$ dos clones produtores de 2H1-IgG3 selecionados por diluição limitante.

Figura 18 - SDS-PAGE de anticorpos 2H1-IgG3 e 4-4-20-IgG3 não purificados. ................. 51 Figura 19 - Produtividade anticorpos $2 \mathrm{H} 1-\mathrm{IgG} 1 / \mathrm{IgG} 3$ por células CHO e NSO mensurada por ELISA.

Figura 20 - Produtividade anticorpos 4-4-20-IgG1/IgG3 por células CHO e NSO mensurada por ELISA.

Figura 21 - Quantificação de anticorpos 2H1-IgG1/IgG3 e 4-4-20-IgG1/IgG3 por ELISA. ..53 Figura 22 - Porcentagem e microscopia de fagocitose de C. neoformans opsonizados com 2H1-IgG3 e 4-4-20-IgG3 por células J774.

Figura 23 - Ensaio de ligação dos anticorpos 2H1-IgG3 e 4-4-20-IgG3 à cápsula de C. neoformans por IFI.

Figura 24 - Cromatografia DEAE de 2H1-IgG3 em modo não ligante..................................57 Figura 25 - Quantificação de anticorpos $2 \mathrm{H} 1$ ao longo dos processos de purificação e

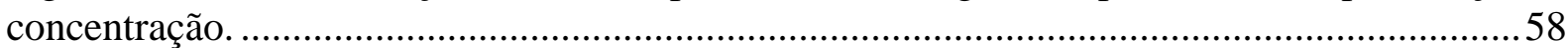

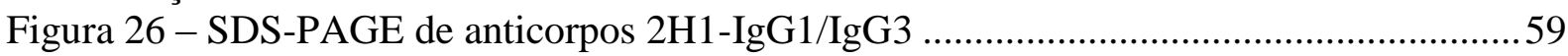
Figura 27 - Ensaio de fagocitose de C. neoformans opsonizado com 2H1-IgG1 e 2H1-IgG359 Figura 28 - Cromatrografia de exclusão molecular de 2H1-IgG1 .......................................... 61 Figura 29 - Quantificação de anticorpo 2H1-IgG1 durante processos de purificação, precipitação, concentração e filtração; e quantificação final de 2H1-IgG3 . .............................62 Figura 30 - SDS-PAGE de anticorpos 2H1 e 4-4-20 em condição desnaturante. 
Figura 31 - Fagocitose de C. neoformans H99 opsonizado com 2H1-IgG1 e 2H1-IgG3 por

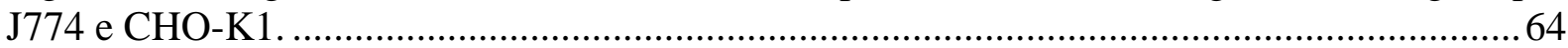
Figura 32 - Fagocitose de BSA marcado com FITC e pHrodo mediada por anticorpos 4-4-20 $-\operatorname{IgG} 1 / \operatorname{IgG} 3$.

Figura 33 - Ensaio de ligação dos anticorpos 2H1-IgG1/-IgG3 à cápsula de C. neoformans 24067 e H99. 68

Figura 34 - Gel filtração de 2H1-IgG1 após concentação por Amicon® Stirred Cells...........69

Figura 35 - Quantificação por ELISA de 2H1-IgG1 antes e após gel filtração.......................70

Figura 36 - SDS-PAGE de anticorpos 2H1 e 4-4-20 após exclusão molecular 


\section{LISTA DE TABELAS}

Tabela 1 - Resultado clínico estimado para tratamento de indução de meningite criptocócica.

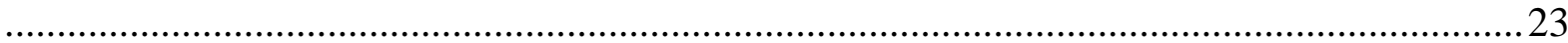

Tabela 2- Anticorpos monoclonais para GXM de $C$. neoformans. ........................................ 28 Tabela 3 - Iniciadores utilizados para amplificação e sequenciamento dos insertos $2 \mathrm{H} 1$ e 4-4-

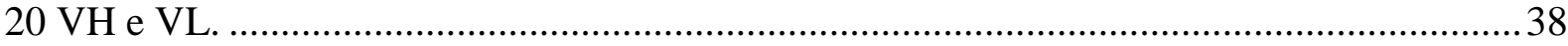

Tabela 4 - Análise da qualidade de sequências nucleotídicas dos clones $2 \mathrm{H} 1$ e 4-4-20......... 47 Tabela 5 - Identidade de sequência de nucleotídeos e aminoácidos dos clones $2 \mathrm{H} 1$ e 4-4-20.48 


\section{LISTA DE SIGLAS}

4-4-20 - IgG recombinante com fração variável para FITC

5-FC - 5-Flucitosina

ABLC - Anfotericina B em complexo lipídico

AIDS -Síndorme da Imunodeficiência adquirida

AmB - Anfotericina B

AmBd - Anfotericina B deoxicolato

BSA - Albumina de soro bovino

C - Região constante do anticorpo

CDR - Região determinante de complementariedade

$\mathrm{CH}$ - Constante pesada

ChIg - Imunoglobulina quimérica

CHO - Células de Ovário de Hamster

Chinês

CR - Receptor de complemento

DEAE - dietilaminoetilanol

DIC - Microscopia de contraste de interferência diferencial

DNA - Ácido Desoxidoribonucléico

ELISA - Ensaio imunoadsorvente ligado a enzima

Fab - Fração de ligação ao antígeno

Fab - Fragmento de ligação ao antígeno

Fc $\gamma \mathrm{R}$ - Receptor de fração cristalizável gamma

FITC - Isociotianato de fluoresceína

GXM - Glucuronoxilomanana

GXMgal - Glucuronoxilomanogalactana
GXM-TT - Glucuronoxilomanana

conjugada a toxina de tétano

$\mathrm{H}$ - cadeia pesada

HAART -Terapia Antirretroviral

Altamente Ativa

HIV - Vírus da Imunodeficiência Humana

HSPs - Proteínas de choque-térmico

IFI - Imunofluorescência indireta

Ig - Imunoglobulina

IMGT - International ImMunoGeneTics

Information System

ITC - Calorimetria por Titulação

Isotérmica

Itgb1 - Integrina beta 1

$\mathrm{L}$ - cadeia leve

LAmB - Anfotericina B lipossomal

LB - Luria-Bertani

LCR - Líquido cefalorraquidiano

Log - Função logaritma

mAbs - Anticorpos monoclonais

MF - Microscopia de Fluorescência

NCBI - National Center for Biotechnology

Information

NMR - Ressonância Magnética Nuclear

NSO - Mieloma não-secretor de imunoglobulina

$\mathrm{Pb}$ - Pares de bases

PBS - Solução salina tamponada com fosfato

PCR - Reação em cadeia pela DNA polimerase 
PDB - Protein Data Bank

$\mathrm{pH}$ - Potencial hidrogeniônico

${ }_{\mathrm{P}} \mathrm{NPP}$ - substrato p-nitrofenil fosfato

PVDF - Fluoreto de polivinilideno

RNA - Ácido Ribonucléico

RNAi - Ácido ribonucleico interferente

SAS - Solução satura com sulfato de amônio

SAXS - Raio-X de pequeno ângulo

SDS - Dodecil-sulfato de sódio

SDS-PAGE - Eletroforese em gel de poliacrilamida com SDS

SFB - Soro fetal bovino

SNC -Sistema Nervoso Central
SPR - Ressoância Plasmônica de

Superfície

T CD4 - Linfócito com Grupamento de diferenciação 4

TB - Terrific Broth

TEMED - Tetrametiletilenodiamina

UV- Luz ultra-violeta com comprimento de onda em nm

V - Região variável do anticorpo

VDJ - Recombinação entre segmentos gênicos variável $(\mathrm{V})$, junção $(\mathrm{J})$ e, em alguns casos, diversidade (D).

VH - Variável pesada 


\section{SUMÁRIO}

1 INTRODUÇÃO -

2. REVISÃO BIBLIOGRÁFICA--- 17

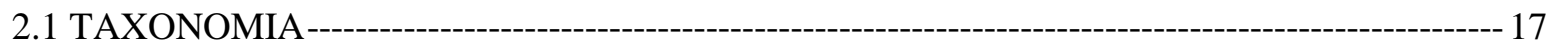

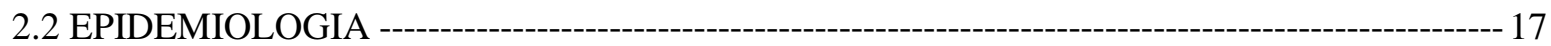

2.3 CRIPTOCOCOSE: TRANSMISSÃO, INFECÇÃO E DOENÇA.--- 19

2.4 CÁPSULA COMO FATOR DE VIRULÊNCIA -- 20

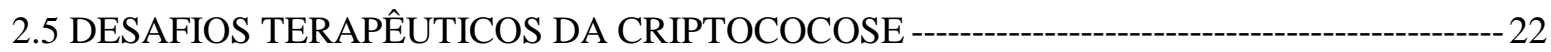

2.6 IMUNOPROFILAXIA E IMUNOTERAPIA PARA CRIPTOCOCOSE --

2.7 CADEIA PESADA ALTERA A AFINIDADE DE ANTICORPOS CONTRA GXM. ------- 26

2.8 IGG 3 INTERAGE COM RECEPTOR DIFERENTE DOS DEMAIS ISOTIPOS. ------------- 30

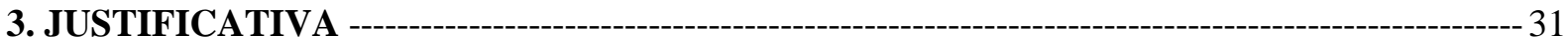

4. OBJETIVOS--- 32

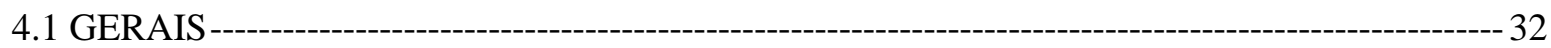

4.1.1 Objetivo específico 1 - Produzir anticorpos recombinantes 2H1-IgG1 e 2H1-IgG3 --- 32

4.1.2 Objetivo específico 2 - Produzir anticorpos recombinantes 4-4-20-IgG1 e 4-4-20-IgG3

4.1.3 Objetivo específico 3 - Determinar se os anticorpos recombinantes se ligam à cápsula de $C$. neoformans e o padrão de ligação gerado por imunofluorescência---:--:------------ 33

4.1.4 Objetivo específico 4 - Determinar o receptor por meio do qual os anticorpos recombinantes medeiam sua função através de ensaios de fagocitose ------------ 33

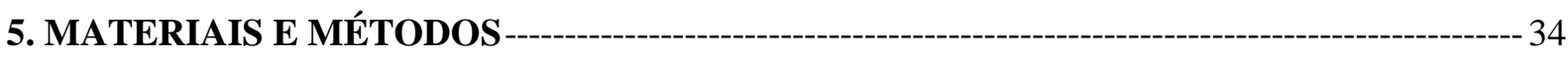

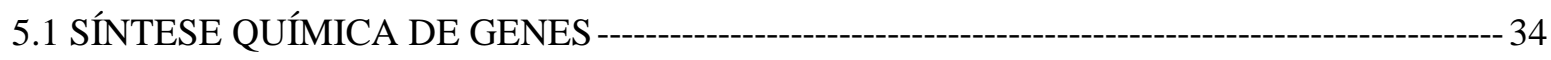

5.2 CLONAGEM DE VH E VL EM VETORES DE EXPRESSÃO. -

5.3 CONFIRMAÇÃO DE CLONES POR DIGESTÃO, PCR E SEQUENCIAMENTO. ----------- 38

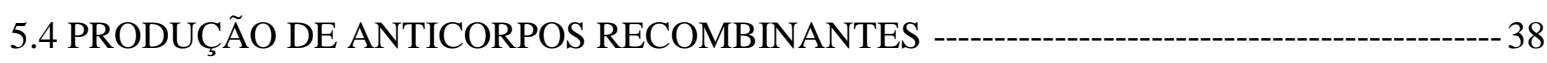

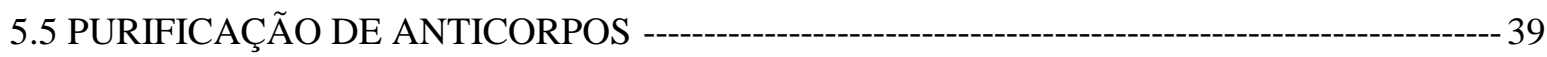

5.5.1 Purificação de anticorpos por dietilaminoetil sefarose (DEAE) ---------------- 40

5.5.2 Precipitação de anticorpos por solução saturada com sulfato de amônio (SAS) ------- 40

5.5.3 Purificação de anticorpos por cromatografia de exclusão molecular. ------------------- 40

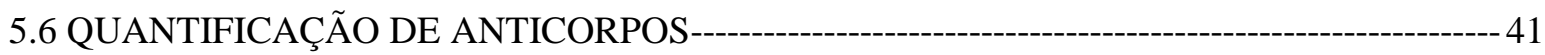

5.6.1 Ensaio imunoadsorvente ligado a enzima (ELISA) - 41

5.6.2 Métodos espectrofotométricos -- 41

5.7 ELETROFORESE EM GEL DE POLIACRILAMIDA COM DODECIL SULFATO DE SÓDIO (SDS-PAGE) --- 
5.8 ENSAIOS FUNCIONAIS DE ANTICORPOS

5.9 SUBSTITUIÇÃO DE FRAGMENTOS CH1 E DE DOBRADIÇA ENTRE 2H1-IGG1 E 2H1IGG3 POR SÍNTESE GÊNICA E CLONAGEM. --- 44

6. RESULTADOS -- 46

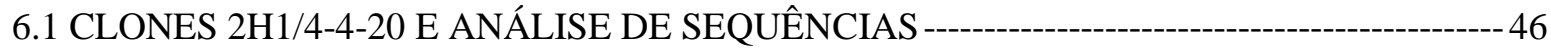

6.2 AVALIAÇÃO DA PRODUTIVIDADE CELULAR DE ANTICORPOS 2H1 E 4-4-20 --------48

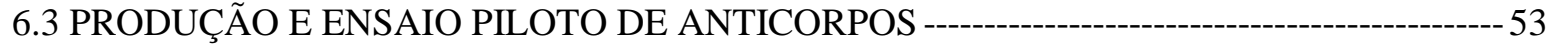

6.4 PRODUÇÃO E TESTES DO PRIMEIRO LOTE DE ANTICORPOS -- 56

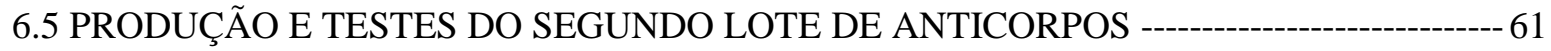

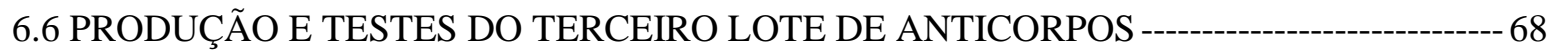

7. DISCUSSÃO--

9. PERSPECTIVAS--- 79

10. REFERÊNCIAS BIBLIOGRÁFICAS --1-- 


\section{INTRODUÇÃO}

Criptococose é uma infecção fúngica invasiva causada principalmente pela espécie Cryptococcus neoformans $(1,2)$, sendo a terceira doença mais prevalente em indivíduos portadores do Vírus da Imunodeficiência Humana (HIV) com Síndrome da Imunodeficiência Adquirida (AIDS) (Figura 1)(2-4). A taxa de letalidadeda criptococose em pacientes com AIDS em geral é superior a30\%, onde a Terapia Antirretroviral Altamente Ativa (HAART) ainda não está disponível $(1,5,6)$. A meningite criptocócica é a causa mais comum de infecção fúngica do sistema nervoso central (SNC)(7-9) e lidera o número de mortes em pacientes com HIV/AIDS na África Subsaariana (Figura 1). É estimado que um milhão de casos de meningite criptocócica ocorram em indivíduos com HIV/AIDS no mundo por ano, resultando em aproximadamente 625.000 mortes $(4,7)$. A América Latina é a região global que apresenta a terceira maior incidência da doença, com cerca de 54.400 casos anualmente $(10,11)$.No Brasil é estimado que 6.832 casos da doença ocorrampor ano(12). Em países desenvolvidos a criptococose apresenta letalidade próxima a $12 \%$ e tem diminuído entre indivíduos com HIV/AIDS devido à disponibilidade da $\operatorname{HAART}(13,14)$.

Figura 1 - Distribuição de meningite criptocócica no mundo e na África Subsaariana.

A) Casos de meninite criptococócica relacionada a $\mathrm{HIV}$

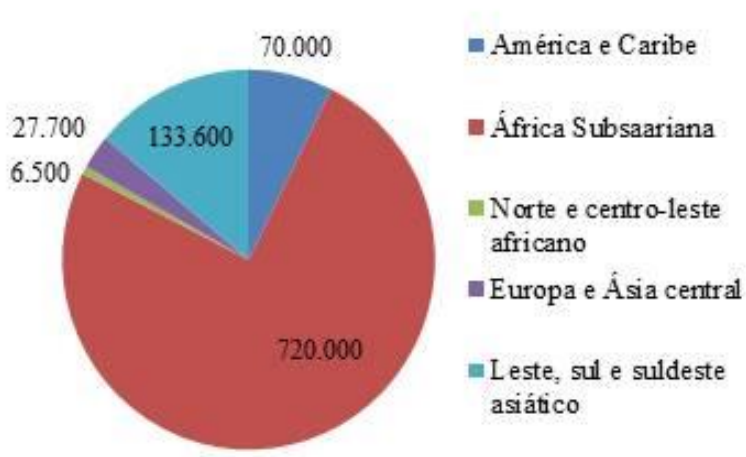

B) Casos de morte na África Subsaariana

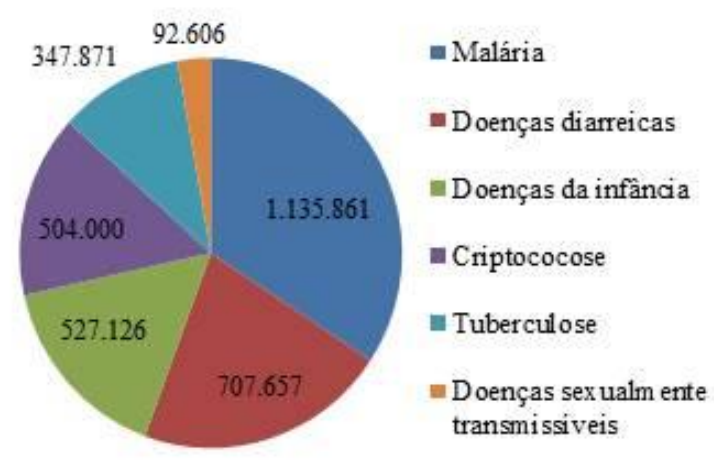

O painel B representa os casos de morte na África Subsaariana com exceção daqueles por HIV/AIDS. Os dados de doenças sexualmente transmissíveis do painel B não incluem os casos de HIV. Adaptado de (7).

O gênero Cryptococcus faz parte do filo dos basidiomicetose conta com alguns fungos patogênicos humanos, classificados dentro do complexo Cryptococcus neoformans que consiste em duas espécies: C. neoformanse C. gattii(8). C. neoformansvar.grubii (sorotipo A), C. neoformans var. neoformans (sorotipo D), e híbridos $\mathrm{AD}(15-17)$, causam doença 
geralmente em pacientes imunocomprometidos, enquanto $C$. gattii causa doença principalmente em pessoas imunocompetentes $(1,18)$. C. neoformans tem uma cápsula de polissacarídeo composta por dois componentes principais, glucuronoxilomanana (GXM) e glucuronoxilomanogalactana (GXMgal) (19). GXM é um polímero de grande massa molecular que compõe maior dimensão da cápsula (20), sendo importante para virulência do fungo(1) e importante alvo terapêutico (20).

As terapias disponíveis contra C. neoformans permanecem insatisfatórias, visto que requerem administração prolongada de drogas antifúngicas e ainda assim são relativamente ineficazes (21). Vacina com GXM de C. neoformans sorotipo A conjugada à toxóide de tétano célula T-dependente(GXM-TT), que é altamente imunogênica (22), resultou em aumento do título de anticorpo sérico se comparado à vacina administrada com o polissacarídeo capsular não conjugado (23). Desde então, vários anticorpos monoclonais (mAbs) contra cápsula de $C$. neoformansforam estudados e conferiram proteção quando administrados passivamente em camundongos infectados com o fungo. Esses estudos mostraram que tanto a especificidade quanto o isotipo dos anticorpos são determinantes importantes da eficácia protetora (24). Dentre os mAbsproduzidos por hibridomas inoculados em tecido peritoneal de camundongos contra a cápsula do fungo, o $18 \mathrm{~B} 7$ (IgG1) se mostrou o mais promissor estando emfase 1 de desenvolvimento clínico para o tratamento da criptococose em humanos (25).

Em alguns experimentos com camundongos tratados com mAbse infectados com $C$. neoformans foram reportados resultados paradoxais de toxicidade do anticorpo, cuja administração acelerou a morte dos animais $(26,27)$. Foi observado que essa toxicidade é isotipo-específica, ou seja, que camundongos tratados com IgG3 têm a doença agravada se comparados a camundongos tratados com IgG1 e outros isotipos. Esseefeito agravador da doença deIgG3 foi correlacionado com a ligação do anticorpo à cápsula de C. neoformans de forma diferente à de IgG1 (24), o que foi mais bem explicado por meio de experimentos detalhados com 3E5 IgG1 e IgG3 (28-30). Nesses experimentos verificou-se que, apesar dos dois anticorpos terem as porções variáveis de sequência idêntica, eles se ligam a células de $C$. neoformans com padrões distintos de imunofluorescência (anular para IgG1 e puntiforme para IgG3) e não competem entre si por ligação ao antígeno emEnsaio imunoadsorvente ligado a enzima(ELISA) de competição, duas evidências de que reconhecem epitopos diferentes de GXM.Correlação semelhante entre efetividade protetora em camundongos e o padrão de fluorescência in vitro foi observada com diversos outros anticorpos monoclonais contra a cápsula de $C$. neoformans(31-33). A visão clássica de queas regiões variável (V) e constante 
(C) são responsáveis respectivamente por ligação ao antígeno e função efetora do anticorpo $(34,35)$ não é uma regra geral, tendo em vista estas evidências de que diferenças nas sequências CHs podem afetar a especificidade e afinidade do anticorpo ao seu antígeno (2830).

O trabalho descrito nesta dissertação faz parte de uma linha de pesquisa mais ampla que visa estudar o mecanismo de ação antifúngica de diferentes anticorpos $\operatorname{IgG}$ contra $C$. neoformans, uma vez que dentre os vários isotipos de mAbs isolados, os mais importantes do ponto de vista farmacológico são os IgGs. Entretanto,apesar de mais de quatro décadas de pesquisa sobre a interação de IgGs com seus receptores, o mecanismo efetor de IgG3 murino permaneceainda obscuro. Anticorpos IgG3 se comportam diferente dos demais, podendo apresentarem-se como crioglobulinas e gerarem resposta prejudicial ao hospedeiro. Dessa forma, estudos comparativos entre IgG3 e outros isotipos são necessários para esclarecer o mecanismo molecular dessas diferenças.

Um dos pontos principais desta linha de pesquisa é o papel da Integrina b-1 (Itgb1) na função de IgG3. Para estudar melhor esse ponto, faz-se necessário o uso de anticorpos recombinantes, o primeiro objetivo específico desta dissertação. No começo do mestrado, durante a produção e validação desses anticorpos, fizemos uma observação interessante em experimentos de imunofluorescência, que evidenciaram padrões distintos de ligação entre IgG1 e IgG3 à cápsula de $C$. neoformans, o que reproduziu resultados descritos anteriormente na literatura para outros anticorpos. O foco de estudo passou a ser direcionado então, principalmente ao entendimento da interferência da cadeia constante na ligação do anticorpo à cápsula, enquanto o trabalho em equipe continuava em paralelo para estudar o papel da Itgb1. Sendo assim, estão presentes na dissertação dados obtidos do foco principal em entender o padrão de ligação diferente de IgG1 e IgG3 à cápsula, mas também trabalhos feitos como parte da equipe que está estudando o papel de Itgb1.

Nesta dissertação, portanto, descrevemos a produção de dois pares de anticorpos IgG1 e IgG3 com regiões variáveis idênticas, estudos sobre suas ligações ao antígeno e suas ações efetoras imunitárias. Os anticorpos foram produzidos com sucesso, se ligaram aos seus alvos e mediaram fagocitose por macrófagos, demonstrando sua funcionalidade. $\mathrm{O}$ estudodos padrões de ligação a GXM de um par de anticorpos IgG1 e IgG3 reproduziu os achados dos mAbs 3E5reportados na literatura. Além disso, mostramos também que os anticorpos IgG3 produzidos medeiam fagocitose por meio de um receptor diferente dos receptores Fc $\gamma$ conhecidos, achados que abrem importantes avenidas de pesquisa que permitirão o entendimento molecular e estrutural das diferenças observadas entre IgG3 e os outros isotipos. 


\section{REVISÃO BIBLIOGRÁFICA}

\subsection{TAXONOMIA}

O gênero Cryptococcus pertence ao filo Basidiomycotae inclui duas espécies patogênicas ao homem, $C$. neoformans e $C$. gattii(8, 18). Baseado em testes de aglutinação(36), existem cinco sorotipos: A, De o híbrido AD (C. neoformans)(15-17)e B e C (C. gattii). Diferenças genéticas dentro da espécie $C$. neoformans levaram à classificação em duas variantes, var. grubii(17)e var. neoformans(1, 8). O complexo C. neoformans foi subdividido em nove tipos moleculares distintos: VNI, VNII e VNB (sorotipo A)(37); VNIII (sorotipo AD); VNIV (sorotipo D); VGI, VGII e VGIII (sorotipo B); VGIII e VGIV (sorotipo C)(38). O VNB era identificado como VNII, mas diferenças moleculares conduziram a essa nova classificação, sendo hoje identificado principalmente na África, Europa e América do Sul (13).

\subsection{EPIDEMIOLOGIA}

Todos os tipos moleculares de C. neoformans causam mais infecções em pacientes imunocomprometidos (78,3\%), comparado a pacientes imunocompetentes (21,7\%). Quanto ao $C$. gattii, a espécie causa mais infecção em imunocompetentes $(85,3 \%)$ do que em imunocomprometidos (14,7\%). C. neoformans apresenta prevalência global, enquanto que $C$. gattii é prevalente nas Américas e no hemisfério Sul (39).O sorotipo A é prevalente sobre os outros sorotipos em quase todo o mundo(40), com exceção deÍndia(41)e Europa, em que o sorotipo D é maiscomum(8). Mundialmente, VNI causa a maioria das infecções em pacientes imunocomprometidos $(83,9 \%$ ) (Figura 2). Na América do Sul, o tipo molecular mais comumente isolado é o VNI (46\%) e VGII (36\%)(39). No Brasil, a maioria das amostras clínicas é do sorotipo A (65\%), seguido de B (17.5\%), D (9\%), AD (5\%) e C (3,5\%)(42). O sorotipo A é prevalente no Sul e Sudeste do Brasil(43, 44), enquanto que o sorotipo B é mais prevalente no Nordeste $(8,44)$. Com exceção a VGIV, os demais tipos moleculares são presentes no Brasil e apresentam frequência na seguinte ordem decrescente: VNI, VGII, VNII, VNIV, VGI e VGIII. Os isolados VNIII e VNI/VGII também foram reportados (13). A Figura 3 mostra um resumo das informações taxonômicas do complexo $C$. neoformans e epidemiológicas da criptococose. 
Figura 2- Distribuição global dos principais tipos moleculares do complexo C. neoformans/C. gattii.
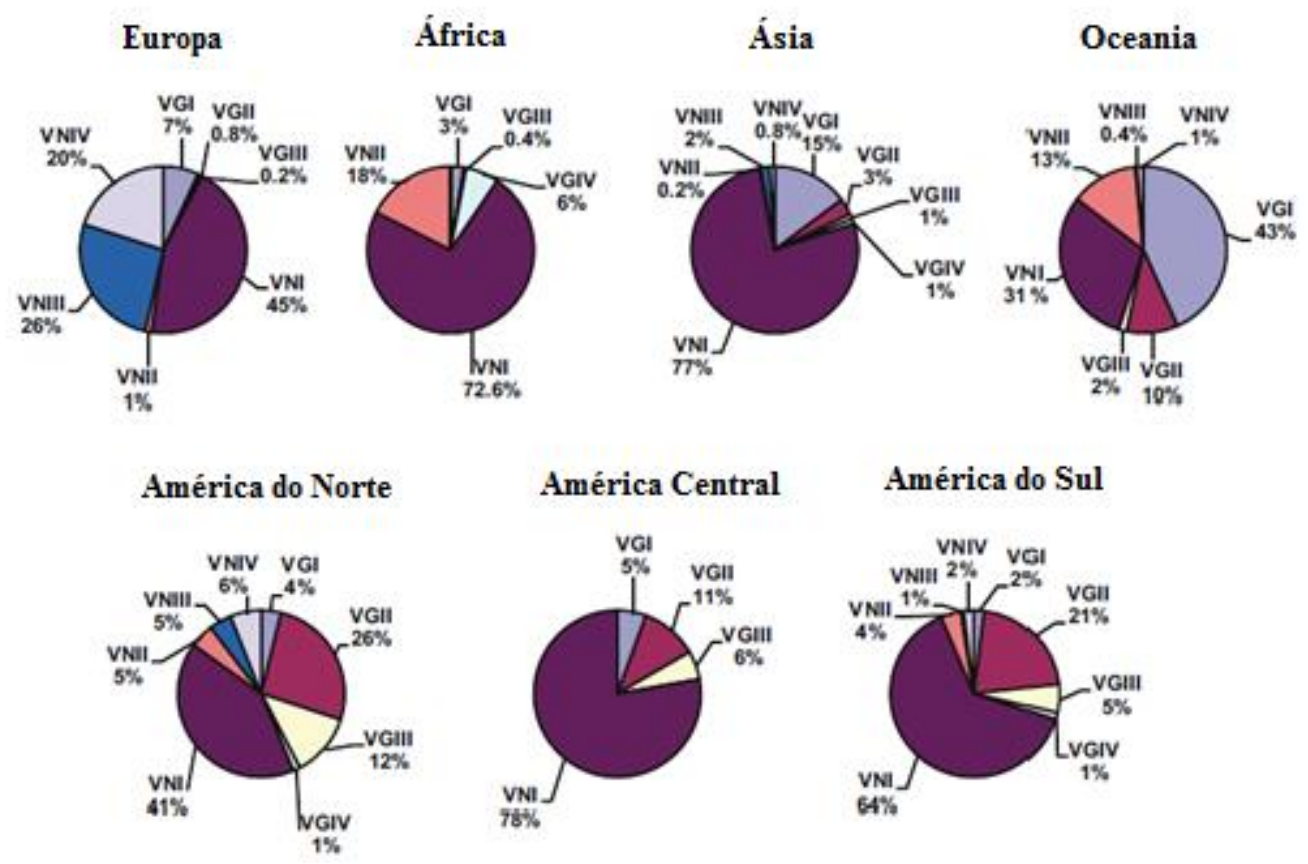

Os tipos moleculares foram identificados a partir de 2.745 isolados coletados globalmente usando URA5Restriction Fragment Length Polymorphism, Amplified Fragment Length Polymorphisms e Multilocus sequence typing. Adaptado de (39).

Figura 3- Correlação taxonômica, molecular, epidemiológica e clínica entre espécies do complexo C. neoformans/C.gattii.

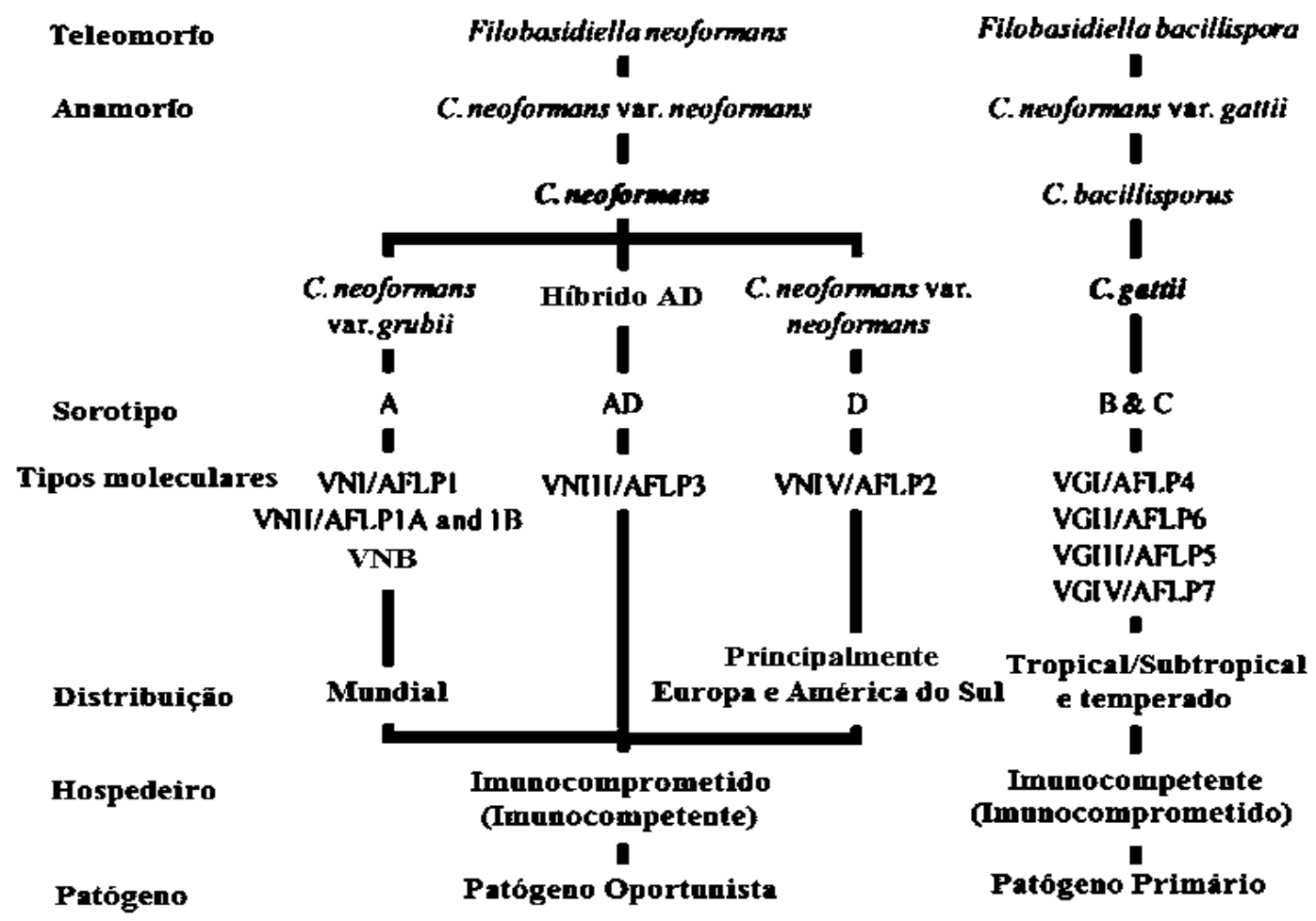

Adaptado de (39). 


\subsection{CRIPTOCOCOSE: TRANSMISSÃO, INFECÇÃO E DOENÇA.}

C. neoformans é encontrado em solo, árvores e em fezes de pássaros (principalmente pombos), podendo interagir com animais selvagens e predadores microbianos (ameba, nematóide) e apresenta distribuição universal $(3,45,46)$. Inalação de propágulos infecciosos, tais como esporos (1-2 $\mu \mathrm{m})$ ou leveduras dissecadas $(\sim 3 \mu \mathrm{m})$ (47)produz infecção tipicamente assintomática que é eliminada ou evolui para forma latente, queconsisteem granulomas nos pulmões ou em linfonodos hiliares (48-50). Em indivíduos imunocomprometidos, o fungo pode se disseminar do pulmão para o $\mathrm{SNC}(51)$ e causar meningoencefalite, geralmente fatal se não tratada $(1-3,47,52)$.

A resistência do fungo ao processo de fagocitose por macrófagos alveolares é importante na infecção pulmonar e latência(53-55). Infecções latentes podem ser reativadas em resposta a imunodepressão, tornando possível a proliferação de $C$. neoformans no pulmão e sua disseminação via corrente sanguínea e/ou linfática para o SNC e outros órgãos(56). $C$. neoformans pode ser encontrado na corrente sanguínea de forma livre ou internalizada em macrófagos e neutrófilos $(57,58)$, pelos quais são transportados via microcapilares para interagir com a barreira hemato-encefálica(59). O ambiente do hospedeiro induz alterações na estrutura e tamanho da cápsula fúngica, levando à formação de uma subpopulação de células gigantes $(25-100 \mu \mathrm{m})$, a qual é refratária à fagocitose e permanece sempre no meio extracelular (Figura 4)(2, 8, 47).

O patógeno pode atravessar a barreira endotelial diretamente e transmigrar pelo citoplasma até o cérebro por mecanismo de "Transcitose" (51)ou carreados por fagócitos mononucleares, mecanismo esse denominado "Cavalo de Tróia" (Figura 4).A transcitose depende de mudança morfológica da célula fúngica, que atravessa diretamente a barreira hemato-encefálica. Já no caso de penetração por meio de Cavalo de Tróia, células fúngicas internalizadas por macrófagos atravessam a barreira endotelial e expulsam o fungo dentro do SNC. Esseprocesso de expulsão mantém a viabilidade de ambas as células (60-62)e ocorre quando o fagossomo se funde à membrana plasmática, liberando as leveduras em espaço extracelular. Uma vez expulso, o fungo pode permanecer livre ou ser transportado a outros macrófagos por transferência intercelular $(8,47,61,63)$. 
Figura 4- Mecanismo de disseminação de C. neoformans pela barreira hemato-encefálica.

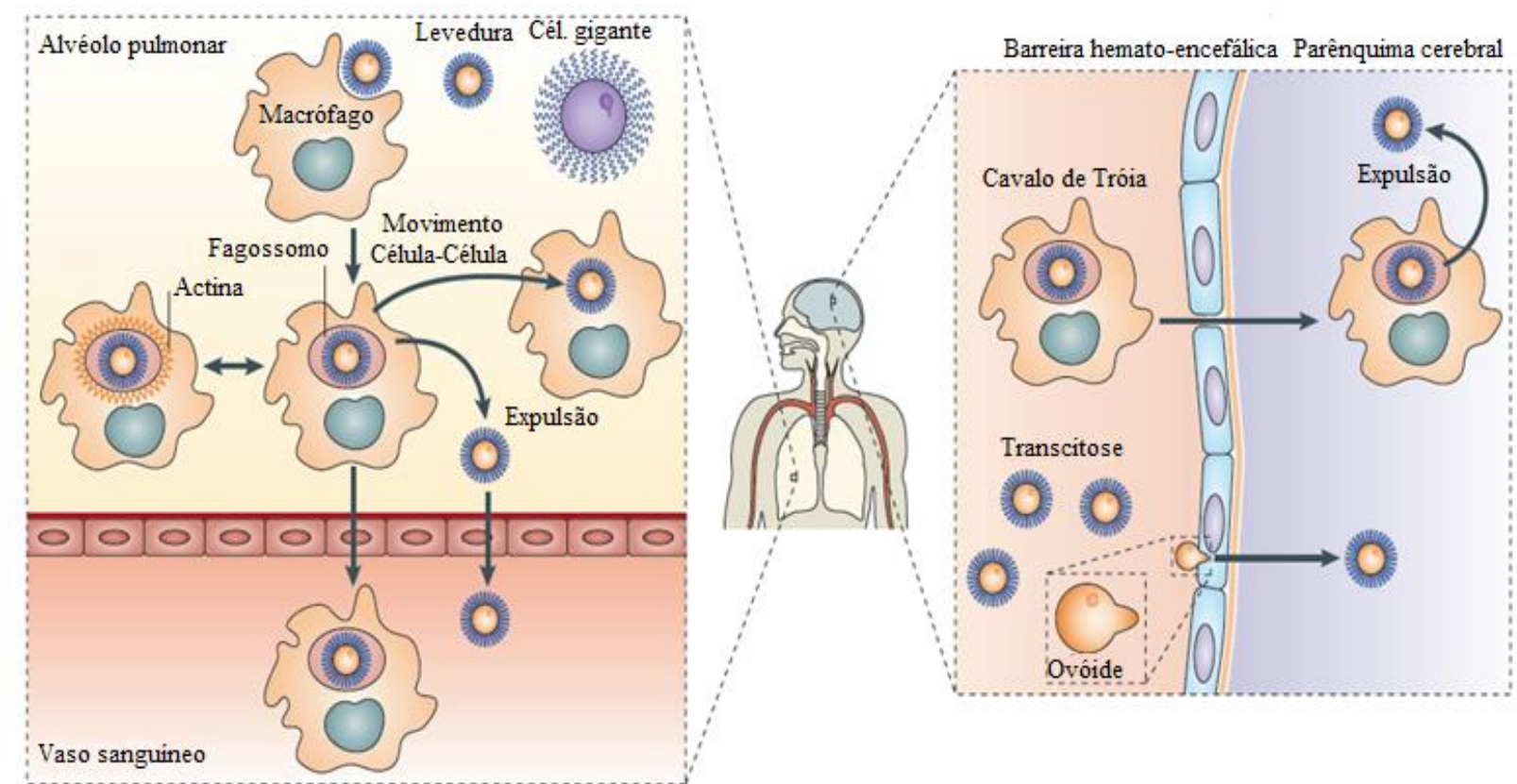

Adaptada de (47)

A meningoencefalite é a forma mais comum de infecção por Cryptococcus. Cerca de 70 a $90 \%$ de pacientes com AIDS e criptococose do SNC apresenta o seguinte quadro clínico de meningite ou meningoencefalite: dor de cabeça, febre, letargia, coma, desordem de personalidade e perda de memória, os quais ocorrem entre a segunda e quarta semana antes do diagnóstico $(31,64)$. Entre outros sintomas neurológicos estão problemas visuais, auditivos, os quais normalmente requerem terapia prolongada (47, 65). A doença é tão grave que sem tratamento antifúngico, $100 \%$ dos pacientes com AIDS e criptococose morrem num período de duas semanas após o diagnóstico (66).

\subsection{CÁPSULA COMO FATOR DE VIRULÊNCIA}

A capacidade de $C$. neoformans influenciar o ambiente intracelular de macrófagos durante sua proliferação, expulsão e transferência intercelular é provavelmente dependente de fatores exportados $(67,68)$. A secreção por sistema vesicular é necessária para entrega de fatores de virulência na superfície celular, tais como a cápsula polissacarídica(69), enzima lacase (a qual sintetiza melanina)(70) e as enzimas fosfolipase B (71)e urease $(47,72)$.

O fator de virulência mais estudado de $C$. neoformans é a cápsula polissacarídica(73). Sua estrutura dinâmica é única entre os fungos patogênicos(74). O mecanismo pelo qual a cápsula contribui para virulência inclui interferência na resposta imune e proteção da célula fúngica de mecanismos imunológicos(75-77). Esses efeitos imunológicos incluem indução a apoptose(78), inibição da produção de anticorpos, depleção do complemento (1), inibição da 
migração de leucócitos(79), interferência na fagocitose (inibição e resistência)(80), inibição da apresentação de antígeno(77), alteração na produção de citocinas e inibição de moléculas de adesão(81). Por outro lado, a cápsula também promove proteção contra mecanismos microbicidas por extinção de radicais livres citotóxicos(81) e resistência ao pH ácido lisossomal (2). Além disso, a cápsula protege células fúngicas presentes no ambiente da desidratação e de predadores ambientais (82). Sua síntese é induzida quando o fungo entra em contato com soro, limitação de ferro e níveis fisiológicos de $\mathrm{CO}_{2}$ no corpo do hospedeiro (1). Por esses e vários outros efeitos, a arquitetura da cápsula é crucial para se entender a patogenicidade de C. neoformans(81).

A cápsula está associada com a parede celular da levedura e é composta primariamente por dois grandes polissacarídeos, o GXM e GXMGal(83). A estrutura básica de GXM consiste numa cadeia de resíduos de manose com substituições de ácido glicurônico e xilose. Resíduos manosil podem ser 6-O acetilado e substituídos por unidades de xilose no $\mathrm{R}-(1,2)$ ou $\mathrm{R}-(1,4)$ dependendo do sorotipo $(84,85)$. GXMGal é formado por uma cadeia de resíduos de galactose com substituições de xilose, manose e ácido glicurônico(77). GXM é uma molécula grande $\left(1-7 \times 10^{6} \mathrm{Da}\right)(86)$ e representa $90-95 \%$ da massa total de polissacarídeos da cápsula, enquanto GXMGal é de menor peso molecular ( $\left.10^{5} \mathrm{Da}\right)(87) \mathrm{e}$ representa $5-10 \%(88)$. Como a composição da cápsula pode variar entre os sorotipos foram observados seis motivos na molécula GXM representados em 106 isolados de Cryptococcus(86), o que permitiu a classificar GXM em seis grupos estruturais(Figura 5)(67, $77,85)$.

Figura 5- Estrutura polissacarídica da cápsula de C. neoformans. 
a
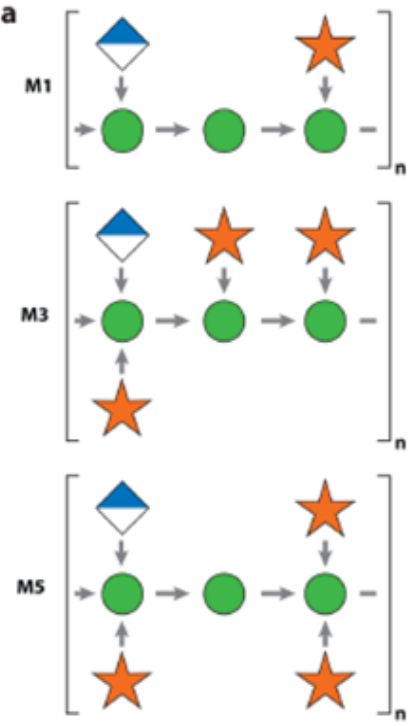
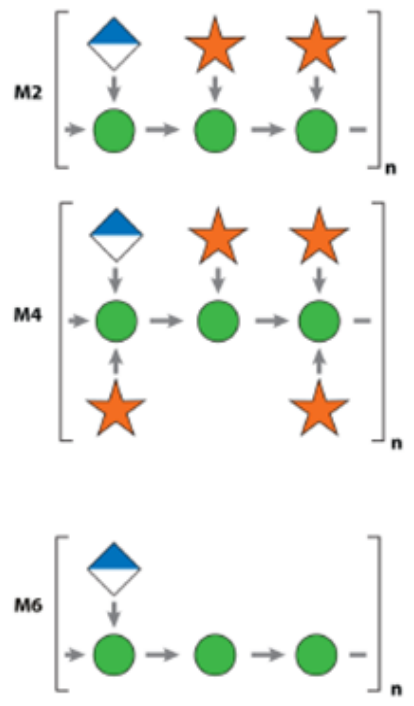

b
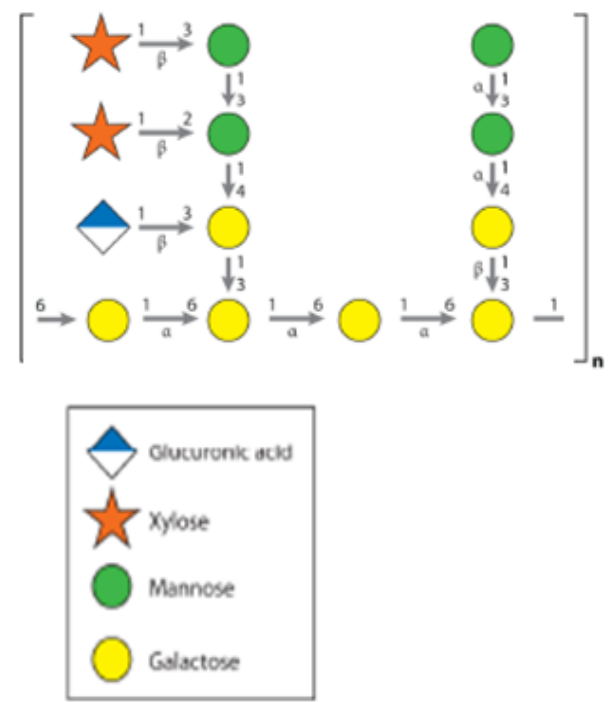

A) Seis grupos estruturais de GXM. Resíduos de manose são ligados $\alpha 1,3$; resíduos de xilose e ácido glicurônico acima da cadeia de manose são ligados $\beta 1,2$; xilose ligada abaixo da cadeia por $\beta-1,4$. B) Estrutura de GXMGal com ramificação trissacarídica. Fonte: (67)

\subsection{DESAFIOS TERAPÊUTICOS DA CRIPTOCOCOSE}

As classes de drogas usadas para o tratamento da meningite criptocócica em pacientes com HIV/AIDS são polienos (anfotericina B)(66, 89), derivados azólicos (fluconazol e itraconazol)e análogos de pirimidina (flucitosina)(66, 90). O mecanismo de ação da anfotericina $\mathrm{B}(\mathrm{AmB})$ está relacionado à presença de anéis macrolídeos, os quais conferem à droga característica hidrofóbica e favorece a ligação aos esteróis, principalmente ao ergosterol da membrana fúngica. Desta forma, a permeabilidade da membrana é alterada permitindo a saída de nutrientes essenciais, o que leva a célula à morte(91). No entanto, a AmB interage também com colesterol da membrana plasmática de humanos e, por isso,geragrande citotoxidade renal, hepática e medular (3, 92-94). A 5-flucitosina (5-FC) inibe a síntese de RNA ao ter seu intermediário metabólico 5-fluoridina convertido no interior da célula fúngica em 5-fluoridina trifosfato, substituindo o ácido uridílico; e altera também a síntese de DNA ao ser convertida em 5-fluorodeoxiuridina monofosfato, um análogo de timidina que leva a parada da síntese do DNA(90, 95). A 5-FC é conhecida por gerar efeitos colaterais severos, tais como hepatotoxicidade (96)e mielotoxicidade(90, 97). Devido à sua toxicidade, a flucitosina tem comercialização proibida em vários países, entre os quais o Brasil(98, 99). Os azóis inibem a enzima lanosterol 14 $\alpha$-demetilase do citocromo P450, envolvida na conversão de lanosterol a ergosterol. A inibição da síntese do ergosterol resulta em aumento da 
permeabilidade da membrana fúngica, lise e morte celular $(3,99,100)$. Os azóis também causam hepatotoxicidade e insuficiência adrenal, mas normalmente isso ocorre se forem utilizados por longos períodos (101); além disso, o medicamento pode ser teratogênico(100, 102).

O padrão ouro no tratamento da neurocriptococose é a combinação de AmB intravenosa e 5-FC oral(66). Contudo, este regime é inviável devido ao alto custo dos medicamentos, da internação hospitalar necessária para aplicação de medicação intravenosa e a necessidade de monitoramento intensivo das funções renal, hepática e medular(103). Outro problema deste regime é que a 5-FCé muito cara e não é licenciada na maioria dos países da África Subsaariana(103).Consequentemente, a monoterapia com fluconazol torna-se o tratamento mais comum em países com recurso terapêutico limitado, embora o mesmo tenha apenas função fungistática em dose padrão $(\leq 400 \mathrm{mg} / \mathrm{d})(103,104)$ e mesmo administrado em doses altas (800-1,200 mg/d) apresenta significativamente menor eficácia do que a AmB (103).

Foi calculada a porcentagem de pacientes com neurocriptococose e AIDS que morreram após 10 semanas de tratamento, baseado em resultados de 18 ensaios e estudos coorte de cada regime. Conforme mostrado na Tabela 1,o tratamento menos eficaz foi a monoterapia com alta dose de fluconazol (800-1,200 mg/d), apresentando média de 54,9\% de letalidade em dez semanas. Tratamento de curta duração com AmB (1 mg/kg/d 5-7d) e fluconazol $(1,200 \mathrm{mg} / \mathrm{d}$ por $14 \mathrm{~d})$ demonstrou média mais eficaz, com taxa de mortalidade de $26 \%$. Este tratamento foi ainda melhor do que regime com fluconazol e 5-FC(Tabela 1)(103). É importante ressaltar que estas taxas de letalidade em pacientes tratados adequadamente para criptococose são muito mais altas do que aquelas observadas em outras doenças graves, como a tuberculose (2-4)e chegam a ser comparáveis com a letalidade observada em surtos de ebola.

Tabela 1 - Resultado clínico estimado para tratamento de indução de meningite criptocócica.

\begin{tabular}{|l|l|l|l|}
\hline Regime de Indução & $\begin{array}{l}\text { Duração da } \\
\text { Indução }\end{array}$ & $\begin{array}{l}\text { Média de Mortalidade } \\
\text { 10 sem. }\end{array}$ & $\begin{array}{l}\text { Média de mortalidade } \\
\text { 1 ano (I.C 95\%) }\end{array}$ \\
\hline Fluc. 800-1,200 mg & $14 \mathrm{~d}$ & $54.9 \%(73 / 133)$ & $60 \%) 54-66 \%)$ \\
\hline 5FC + fluc. 1,200 mg & $14 \mathrm{~d}$ & $43.5 \%(20 / 46)$ & $50 \%(39-61 \%)$ \\
\hline AmBd + fluc.1 1,200 mg & $5-7 \mathrm{~d}$ & $26 \%(33 / 127)$ & $34 \%(28-41 \%)$ \\
\hline AmBd & $14 \mathrm{~d}$ & $34.4 \%(128 / 372)$ & $42 \%(38-51 \%)$ \\
\hline AmBd + fluconazol 800 mg & $14 \mathrm{~d}$ & $30 \%(61 / 203)$ & $38 \%(32-46 \%)$ \\
\hline AmBd + 5FC & $14 \mathrm{~d}$ & $26.8 \%(62 / 231)$ & $35 \%(28-41 \%)$ \\
\hline
\end{tabular}

5FC: $100 \mathrm{mg} / \mathrm{kg} / \mathrm{d}$, ambd: $0.7-1 \mathrm{mg} / \mathrm{kg} / \mathrm{d}$. Adaptado de: (103) 


\subsection{IMUNOPROFILAXIA E IMUNOTERAPIA PARA CRIPTOCOCOSE}

Dadaa gravidade da criptococose, sua grande incidência e as limitações das drogas antifúngicas atuais(92, 96, 101), diversos grupos têm buscado soluções para a doença baseadas no sistema imunitário do hospedeiro. Uma primeira ferramenta importante seria uma vacina, a ser usada na profilaxia da doença $(105,106)$. Quatro tipos de componentes do fungo permitem que a resposta imune durante a infecção seja a favor do hospedeiro: os polissacarídeos(107, 108), proteínas(109, 110), lipídeos(111)e pigmentos de melanina(112). No entanto, apenas os polissacarídeos e as proteínas são candidatos ao desenvolvimento de vacina(77). Apesar da cápsula de $C$. neoformans ser um importante fator de virulência e capaz de induzir a produção de anticorpos contra $\operatorname{GXM}(69,73,79)$, a imunização com o antígeno ocorre via linfócito $\mathrm{T}$ independente e por isso não induz a amplificação da resposta humoral mediada por célula $\mathrm{T}$ auxiliar, apresentando baixo potencial imunogênico $(77,113,114)$. Essa baixa imunogenicidade de GXM pode ser resolvida quando associada a proteínas carreadoras(115). A última vacina foi feita usando GXM-TT e resultou em antígeno altamente imunogênico, capaz de induzir a produção de anticorpos protetores em camundongos(23, 116). No entanto, a imunização ativa com GXM-TT requer proteção mediada por células $\mathrm{T}$ CD4(22), o que põe em questão seu potencial efetivo em hospedeiros imunocomprometidos(117).Dado que os antígenos proteicos têm a capacidade de induzir o processamento e apresentação de peptídeos, eles são considerados protótipos para indução de resposta mediada por célula(77). Por isso, há grande interesse na identificação de antígenos proteicos que sirvam para desenvolvimento de vacinas(109, 110). Infecção por criptococos gera resposta de anticorpos rápida e forte contra proteinas fúngicas, tais como as proteínas de choque térmico (HSPs)(118), mas atualmente não existe evidência que essas respostas contribuem para a proteção do hospedeiro(77). Por outro lado, antígenos proteicos como as manoproteínas geram uma resposta forte mediada por célula, a qualfoi associada com proteção parcial contra dose letal do fungo em camundongos(119). No entanto, as manoproteínas mostraram ser componente responsável por reações de hipersensibilidade do tipo tardia (120), além de não serem recomendadas para tratamento de criptococose em pacientes com HIV,já quea proteína estimula a proliferação de linfócitos e liberação de citocinas por mononucleares periféricos o que, consequentemente, induz também a proliferação do vírus (121). 
A imunoprofilaxia, entretanto, tem limitações no caso da criptococose. A doença acomete principalmente pessoas imunodeprimidas, que consequentemente podem não conseguir gerar respostas imunitárias robustas o suficiente para proteção(122-124). Além disso, a criptococose não acontece após exposição aguda ao fungo, mas sim por meio de reativação de infecção latente; de fato, todo ser humano adulto parece ter anticorpos contra $C$. neoformans circulantes, então a vacina pode não surtir efeito algum(77). A imunoterapia com anticorpos monoclonais, entretanto, desperta grande interesse como uma alternativa importante no tratamento da criptococose $(125,126)$. A imunorregulação de mAbs promove aumento da opsonização e fagocitose, inibe diretamente a indução da cápsula do fungo, modula a produção de citocinas e resposta inflamatória (3) e aumenta eficácia de drogas antifúngicas $(24,127-130)$.A administração de mAbs contra cápsula de $C$. neoformans potencializa também a eficácia de fluconazol e flucitosina (77).Diversos grupos produziram anticorpos contra a cápsula nas décadas de 1980 e 1990 (24, 126, 131, 132), mas os mais importantes para este trabalho sãodois conjuntos independentes de anticorpos murinosproduzidos por hibridomas pelo grupo do Dr. Casadevall $(23,133)$. Sete anticorpos foram derivados de camundongo BALB/c infectado com C. neoformans sorotipo A e 22 foram derivados de camundongo BALB/c imunizado com GXM-TT de C. neoformans sorotipo A. Esses mAbs foram dos tipos IgM, IgG3, IgG1 e IgA com a cadeia leve Kappa. Apenas dois padrões distintos da região determinante de complementariedade (CDR) 3 de 7 aminoácidos estão presentes em mAbs de camundongos imunizados, sugerindo que esses hibridomas foram derivados de apenas dois diferentes precursores de célula B. Baseado no padrão de rearranjo da cadeia pesada e homologia de sequência de CDR3, os hibridomas 2D10, 2H1, 3E5, 18G9 e 13G12 foram derivados de um dos precursorese os hibridomas 4G9, 7G7, 9FII, 12A1, 13F1, 14EI, 15E8, 16E4, 18B7 e 25G12 foram derivados do outroprecursor de célula B (134).

Estudo posterior comparou a estrutura primária e idiotipos destes mAbs isolados a partir de camundongos imunizados comGXM-TT. Um padrão importante surgiu dessa análise, que revelou vários clones com 11 aminoácidos na CDR3do domínio VH; os anticorpos que apresentaram esse perfil, tais como 2H1, 18B7, 3E5, 12A1 e 13F1, foram classificados como pertencentes à classe II (125, 135).Apesar da grande similaridade de sequência de aminoácidos entre estes anticorpos, resultante do fato de eles serem originários de somente dois clones de célula B(134)eles têm uma série de diferenças funcionais importantes que serão detalhadas abaixo. 
O primeiro destes anticorpos testado como imunoterapia passiva em modelos animais foi o $2 \mathrm{H} 1$, umIgG1 que prolongou a sobrevivência de camundongos infectados com dose letal deC. neoformans $(23,115)$. $2 \mathrm{H} 1$ foi extensivamente caracterizado, tendo inclusive sua estrutura tridimensional caracterizada por cristalografia de raios $\mathrm{X}(125,136,137)$. Apesar deser o candidato mais promissorpara desenvolvimento clínico, o anticorpo $2 \mathrm{H} 1$ apresentou problemas de agregação durante sua purificação(125). Por isso, optou-se por desenvolver outro IgG1 murino, conhecido como 18B7, que é proximamente relacionado ao $2 \mathrm{H} 1 \mathrm{em}$ sua região variável, mas não idêntico (117). Fatores que contribuíram para a seleção de 18B7 para o desenvolvimento clínico foram: alta afinidade a $\operatorname{GXM}(117)$, ser protetor em camundongos infectados com C. neoformans, apresentar um anticorpo quimérico camundongo-humano protetor(138), ausência de toxicidade em macacos em triagem terapêutica (139)e ausência de problemas significantes durante sua purificação(125).O ensaio clínico fase I com o mAb 18B7teve resultados promissores em relação à tolerância e eficácia na eliminação de $C$. neoformans em voluntários tratados com o anticorpo $(25,125)$.

\subsection{CADEIA PESADA ALTERA A AFINIDADE DE ANTICORPOS CONTRA GXM.}

Anticorpos são proteínas heterodiméricas compostas por duas cadeias pesadas $(\mathrm{H})$ e duas cadeias leves (L)(140). Cada cadeia H e L contém um domínio V que combinados definem o sítio de ligação ao antígeno(141). No genoma de mamíferos existem cinco grandes classes de domínio constante pesado $(\mathrm{CH})$ que determinam o isotipo de anticorpo (142). É atualmente definido que $\mathrm{CH}$ exerce sua função efetora sem afetar diretamente a afinidade ou especificidade de ligação ao antígeno. Essa definição, que data da década de 1960,implica que a diversidade de anticorpos é proveniente da recombinação $\mathrm{V}(\mathrm{D}) \mathrm{J}$, das mutações somáticas nas regiões CDR do domínio V e da mudança de classe por recombinação(143, 144). Estudos das três últimas décadas, incluindo de cristalografia validaram extensivamente esse princípio (141, 145, 146). Dessa forma, a visão clássica da função do anticorpo é que os domínios V são exclusivamente responsáveis pela afinidade e especificidade do anticorpo, enquanto que o domínio constante é responsável pelas propriedades biológicas, como ativação do complemento, ligação ao receptor Fc, avidez e meia vida no soro(147, 148)(Figura 6). Esse conceito postula que quando células B mudam uma região $\mathrm{CH}$ para outra, a avidez e funções efetoras do anticorpo mudam sem alterar a afinidade e especificidade ao antígeno(143, 144). Contudo, anticorpos de região variável idêntica que manifestam diferenças na ligação ao 
antígeno, na especificidade fina e no reconhecimento idiotípico já foram observados, desafiando assimum dogma central da imunologia $(142,149)$.

Figura 6- Estrutura clássica de anticorpo IgG.

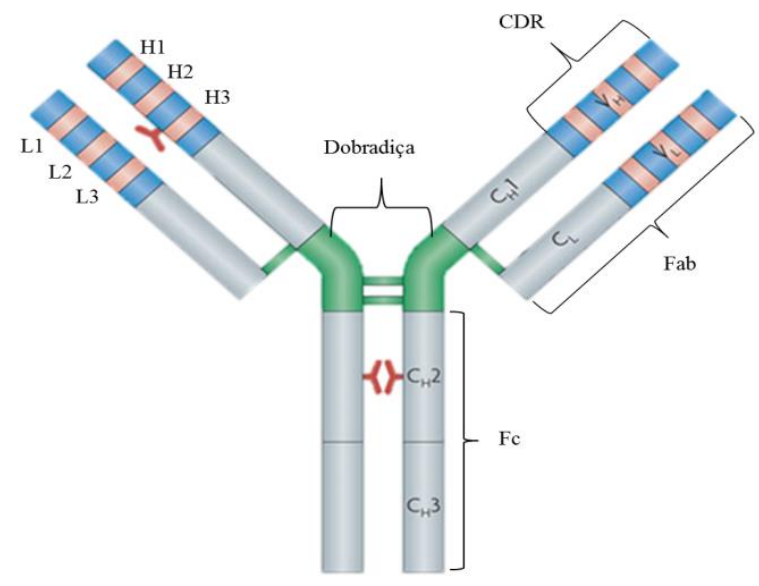

Adaptado de (147)

Várias evidências sugerem que diferenças nas sequências $\mathrm{CHs}$ podem afetar a especificidade e afinidade do anticorpo ao seu antígeno(34, 142, 145, 150). Foi observado que anticorpos que conservavam o mesmo paratopo e variavam a cadeia constante (mudando de classe ou isotipo) apresentavam diferente papel protetor quando camundongos infectados com C. neoformans foram tratados com os mAbs(24, 28-30). Camundongos infectados com o fungo e tratados com IgG1, IgG2a, IgG2b provenientes do hibridoma 3E5 evoluíram para a cura em cerca de 17 dias após tratamento, enquanto aqueles tratados com o isotipo IgG3 morreram precocemente após 12 dias, antes mesmo dos animais não tratados com anticorpo algum(81, 150). Ensaios de fagocitose de $C$. neoformans utilizando macrófagos como fagócitos reproduziram o achado in vivo, evidenciando maior porcentagem quando o fungo foi

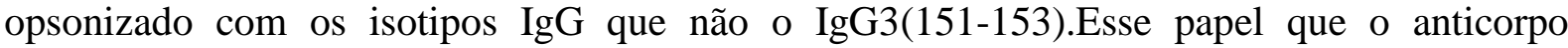
apresenta em causar danos ou de não fornecer resposta protetora ao hospedeiro é denominado agravante de doença ou nãoprotetor(33, 81, 154).

Para entender melhor o mecanismo protetor dos mAbs contra C. neoformans, ensaios de Imunofluorescência Indireta (IFI)foram realizados com esses anticorpos de classe II(125, 135). Interessantemente, os mAbs apresentam distintas formas de se ligar à cápsula do fungo, resultando em padrões de ligação reprodutíveis(24, 28-30). Quando 3E5-IgG1 se liga ao $C$. neoformans é observada a formação de um anel fluorescente envolto à sua cápsula, denominado padrão de ligação anular. Já quando IgG3 se liga à levedura são observados pontos fluorescentes ao redor da cápsula, denominado padrão de ligação puntiforme $(81,150)$ 
Essa correlação entre padrão de imunofluorescência e proteção conferida pelo anticorpo a camundongos infectados com $C$. neoformans já foi observada com outros anticorpos $(135,150,155)$. Animais tratados com a IgM 13F1 têm a doença agravada se comparados a camundongos tratados com a IgM 12A1 e a outros isotipos que tratam a doença(155).Assim como 3E5-IgG1, que é protetor, a IgM protetora 12A1 se liga à cápsula de C. neoformanscom padrão anular; da mesma forma, a $\operatorname{IgM}$ não-protetora $13 \mathrm{~F} 1$ se liga à capsula com padrão puntiforme(135), semelhante ao também não-protetor 3E5- $\operatorname{IgG} 3(24,28$ 30). Conforme descrito acima, tanto 13F1 quanto 12A1 são anticorpos de classe II (125, 135)e são derivados do mesmo clone de células B; a única diferença entre estes dois anticorpos é que 13F1 apresenta mutação de dois aminoácidos na cadeia variável pesada (VH), se comparado a 12A1 $(135,150)$ (Tabela 2).

Tabela 2- Anticorpos monoclonais para GXM de C. neoformans.

\begin{tabular}{|c|c|c|c|c|}
\hline Anticorpo & Isotipo & Padrão de ligação & Protetor & Observações \\
\hline $2 \mathrm{H} 1$ & IgG1 & Anular & Sim & $\begin{array}{l}\text { O primeiro mAb anti-GXM com estrutura } \\
\text { cristalográfica resolvida (PDB ID: } 2 \mathrm{H} 1 \mathrm{P}) \text { (137) }\end{array}$ \\
\hline \multirow[t]{2}{*}{$3 \mathrm{E} 5$} & $\begin{array}{l}\text { IgG1, } \\
\text { IgG2a, } \\
\text { IgG2b }\end{array}$ & Anular & Sim & \multirow[t]{2}{*}{$\begin{array}{l}\text { Isotipos de IgGcom região variável idêntica } \\
\text { (154) }\end{array}$} \\
\hline & IgG3 & Puntiforme & Não & \\
\hline $18 \mathrm{~B} 7$ & IgG1 & Anular & Sim & $\begin{array}{l}\text { Em desenvolvimento clínico para terapia de } \\
\text { criptococose }(25)\end{array}$ \\
\hline $12 \mathrm{~A} 1$ & IgM & Anular & Sim & \multirow{2}{*}{$\begin{array}{l}\text { Derivados do mesmo clone de célula } \mathrm{B} \text {, } \\
\text { diferindo em resíduos que sofreram maturação } \\
\text { de afinidade na região VH (155) }\end{array}$} \\
\hline $13 \mathrm{~F} 1$ & $\operatorname{IgM}$ & Puntiforme & Não & \\
\hline
\end{tabular}

Experimentos semelhantes foram feitos com anticorpos quiméricos, contendo os domínios variáveis de $18 \mathrm{~B} 7(25,125)$ e as regiões constantes dos isotipos humanos IgG1, IgG2, IgG3, IgG4, IgM e IgA. Estes anticorpos quiméricosapresentaram diferente padrão de ligação à GXM, sendo o padrão de chIgMe chIgG3 puntiforme e chIgG1, chIgG2, chIgG4 e chIgA anular(Figura 7). ELISA de competição revelou que anticorpos que melhor competem por ligação ao epitopo apresentam padrão de ligação semelhante. Por exemplo, experimento entre mAb 18B7 e anticorpos quiméricos revelou que 18B7 compete com chIgG1, chIgG2 e chIgG4, mas não com chIgM ou chIgG3 $(113,138)$. 
Figura 7 - Padrão de imunofluorescência anular e puntiforme dependente de $\mathrm{CH}$.

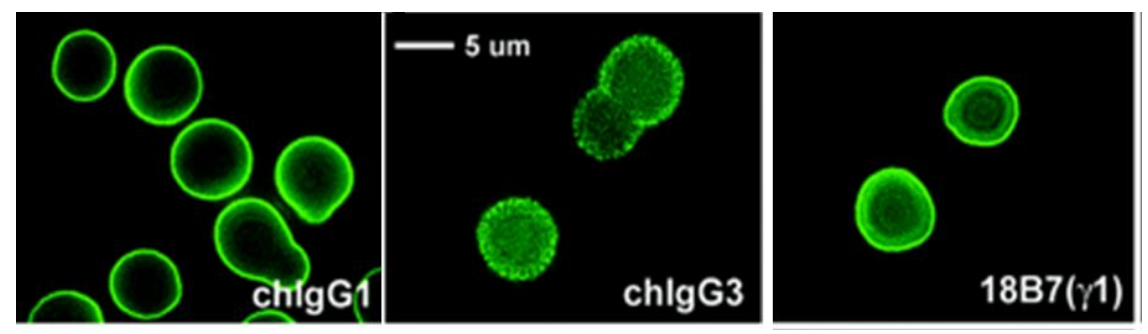

As figuras representam resultado de IFI de anticorpos quiméricos (chigG1 e chigG3) e do mAb 18B7 original contra GXM de $C$. neoformans. Para deteç̧ão foram utilizados anticorpos secundários de cabra anticamundongo marcados com isotiocianato de fluoresceína (FITC). Fonte: (81)

A condição crítica para ligação antígeno-anticorpo é a formação de um complexo específico entre ambos $(143,144,147)$. Para compreensão da interação dessas duas macromoléculas biológicas é requerido conhecimento detalhado das características estruturais e funcionais desse complexo(143, 144, 147, 148). A estrutura do complexo antígenoanticorpo pode ser descrita usando cristalografia por raios $\mathrm{X}$ e modelos computacionais. A atividade funcional pode ser compreendida pela constante cinética de associação/dissociação, de equilíbrio (determinada pela variação da energia livre de Gibbs) e por parâmetros termodinâmicos de ligação do complexo(156). Experimentos de Ressoância Plasmônica de Superfície (SPR)(142), Calorimetria por Titulação Isotérmica (ITC)(34)e de Ressonância Magnética Nuclear (NMR)(157, 158), os quais utilizam de tais princípios, foram aplicados para determinar se a afinidade/especificidade do mAb ao antígeno GXM é alterada quando a cadeia variável é mantida e a cadeia constante é trocada(141, 159). Resultado de SPR evidenciou aumento da afinidade dos isotipos a GXM na seguinte ordem IgG2b> IgG2a> IgG3> IgG1(142). Essas observações sugerem que diferenças estruturais no domínio CH1 são responsáveis por alterar a constante de afinidade e, consequentemente, variar a ligação ao antígeno(137, 142). O mecanismo para esse efeito parece envolver a transformação da estrutura secundária do sítio de ligação do anticorpo em uma forma cineticamente mais competente em anticorpos que apresentam afinidade de ligação aumentada(142). Issopode ser correlacionado com o fato de a flexibilidade do anticorpo ser controlada pelo domínio $\mathrm{CH} 1$ e região de dobradiça $(137,142,160)$.

Estudo utilizando Espalhamento de RaiosX de Pequeno Ângulo (SAXS) para análise conformacional de 3E5 IgG3 Fab e 2H1 IgG1 (137)confirmou a afirmação de que o padrão de ligação IgG1 e IgG3 é alterado devido a diferenças na angulação da cadeiaconstante geradas 
pela região de dobradiça e pela região de junção entre o $\mathrm{CH} 1$ e a região variável $(137,142$, 149).

\subsection{IGG 3 INTERAGE COM RECEPTOR DIFERENTE DOS DEMAIS ISOTIPOS.}

Apesar do anticorpo IgG3 ser o principal isotipo produzido contra carboidratos e epitopos de repetição em camundongos, seu papel na resposta imune ainda não é totalmente entendido $(152,153)$. Há pouco mais de trinta anos foi demonstrado que IgG3 possui receptor independente das demais subclasses de IgG murinas(151-153). Ao longo dessas três décadas, alguns trabalhos sugeriram que IgG3 interage com Fc $\gamma \mathrm{RI}(152,153,161)$, mas diversos grupos não conseguiram reproduzir este achado e observaram fagocitose mediada por IgG3 mesmo quando os receptores FcyR estavam bloqueados $(117,153,162)$.

Durante seu pós-doutorado, o co-orientadordeste trabalho,Dr. André Nicola, e outros colegas do Albert Einstein College of Medicine, New York, realizaram um estudo no qual foram transduzidos individualmente cerca de80.000 diferentes RNAs interferentes (RNAi) em macrófagos J774 contra 15.000 genes de camundongos com objetivo de identificar o receptor de IgG3. Destes alvos gênicos, foram selecionados aqueles em que a redução da expressão gênica resultou em macrófagos com menor capacidade de ligação àIgG3, mas com capacidade inalterada de ligar IgG1. Ao final, dois clones de RNAi demonstraram redução considerável da ligação de IgG3 e de fagocitose mediada especificamente por IgG3. Os dois clones tinham como alvo a Itgb1. Uma série de testes subsequentes de perda e ganho de função demonstraram que a presença de Itgb1 está associada à fagocitose mediada por IgG3, mas não à IgG1. Esses resultados levantam uma pergunta muito importante que ainda não foi respondida: Itgb1 é o receptor de IgG3 procurado desde os anos 1980 ou é somente uma proteína acessória necessária para o funcionamento desse receptor ainda não descoberto? Este trabalho faz parte da linha de pesquisa que busca responder essa pergunta, estudando o papel de Itgb1 na fagocitose mediada por IgG3 e as possíveis aplicações práticas que isso possa ter. 


\section{JUSTIFICATIVA}

Tendo em vista as desvantagens das drogas disponíveis no mercado para tratamento de criptococose meningocócica, os anticorpos monoclonais gerados a partir de imunização de camundongos com GXM-TT se tornaram uma ferramenta terapêutica promissora contra $C$. neoformans. Visto que os anticorpos monoclonais murinos podem gerar resposta protetora e nãoprotetora em camundongos, a depender de seu isotipo ou de pequenas variações no domínio VH, é importante que eles tenham seu mecanismo efetor melhor compreendido a fim de utilizar em seres humanos o anticorpo mais eficiente possível no tratamento da doença. Diversos estudos feitos ao longo das últimas três décadas mostraram uma associação entre a resposta imune protetora/agravante de doença e os isotipos de anticorpos, com o isotipo IgG1 conferindo imunidade protetora e o isotipo $\operatorname{IgG} 3$ conferindo imunidade nãoprotetora ou agravante de doença.

A observação de que anticorpos protetores e nãoprotetores apresentavam uma correlação no padrão de imunofluorescência levantou a hipótese que a estrutura tridimensional da cadeia variável idêntica entre os isotipos era, de alguma forma, alterada pela conformação da cadeia constante dos anticorpos. Essa possibilidade coloca em questão um importante dogma em que acreditamos há anos: a cadeia variável é a única responsável pela ligação ao antígeno. Um entendimento detalhado sobre o mecanismo molecular e estrutural, pelo qual a porção constante da cadeia pesada afeta a região variável a ponto de alterar a atividade imunitária de um anticorpo é então, crucial para que sejam criados anticorpos seguros para terapia da criptococose.

Uma segunda explicação para diferentes isotipos de IgG de cadeia variável idêntica gerarem diferentes papéis protetores em camundongos pode ser o fato de que eles interagem com receptores diferentes. Os receptores dos isotipos IgG1, IgG2a e IgG2b de camundongo são amplamente conhecidos, enquanto IgG3 não apresenta afinidade mensurável a nenhum recepor Fc $\gamma$ conhecido. Desde 1981 foi levantada a hipótese desse anticorpo apresentar receptor independente, diferente daqueles que se ligam à porção $\mathrm{Fc}$ dos outros isotipo de $\mathrm{IgG}$. Um colaborador direto deste projeto, o Dr. André Nicola, e seus colegas identificaram a Itgb1 como possível receptor ou correceptor na fagocitose mediada por IgG3. Uma série de experimentos de perda e ganho de função comprovam essa hipótese, mas o mecanismo molecular de interação entre IgG3 e Itgb1 não foi demonstrado. Um melhor conhecimento sobre esse mecanismo também pode contribuir para o desenvolvimento de anticorpos terapêuticos mais seguros e eficazes. 


\section{OBJETIVOS}

\subsection{GERAIS}

Os anticorpos monoclonais podem ser bastante úteis na terapia da criptococose, mas é importante conhecer melhor o mecanismo pelo qual eles protegem o hospedeiro contra $C$. neoformans para desenvolver terapias eficazes e seguras. Uma observação muito importante para esta linha de pesquisa da qual a atual dissertação faz parte é a mudança na capacidade protetora de um mesmo anticorpo IgG quando seu isotipo é alterado. O objetivo geral deste trabalho então, é entender o mecanismo molecular pelo qual diferentes isotipos IgG de região variável idêntica alteram a resposta imunitária.

\subsubsection{Objetivo específico 1- Produzir anticorpos recombinantes 2H1-IgG1 e2H1-IgG3}

Os anticorpos monoclonais 3E5 foram os únicos a terem seu padrão de ligação a C.neoformans e interação com receptores celulares (Fc e Itgb-1) estudados. Desta forma, é importante estudar anticorpos IgG com cadeia variável diferente da de 3E5 para avaliar se os resultados obtidos com 3E5 são generalizáveis. A estratégia experimental de usar anticorpos recombinantes permite também uma série de experimentos que possibilitarão determinar com precisão quais resíduos de aminoácidos e/ou tipos de modificação pós-traducionais do anticorpo IgG3 são necessários para essas mudanças no padrão de ligação a $C$. neoformans e a receptores celulares. $\mathrm{O}$ anticorpo $2 \mathrm{H} 1$ é um bom candidato para fazer os anticorpos recombinantes por ser um dos anticorpos contra a cápsula de $C$. neoformans mais estudados e também por ser o único, além de 3E5, a ter estrutura tridimensional caracterizada por cristalografia, o que facilitará estudos estruturais futuros.

\subsubsection{Objetivo específico 2- Produzir anticorpos recombinantes 4-4-20-IgG1 e 4-4-20- IgG3}

Além de avaliar o mecanismo efetor de anticorpos contra C. neoformans, é importante também avaliar se as diferenças funcionais entre IgG3 e os outros isotipos de IgG são semelhantes em anticorpos contra outros antígenos. Neste caso, anticorpos recombinantes de alta afinidade contra um hapteno comumente utilizado em laboratório (FITC) são uma excelente opção. 


\subsubsection{Objetivo específico 3 -Determinar se os anticorpos recombinantes se ligam à cápsula deC. neoformans e o padrão de ligação gerado por imunofluorescência}

Além de testar a capacidade dos anticorpos $2 \mathrm{H} 1$ recombinantes de reconhecer seu antígeno na superfície das células de $C$. neoformans, experimentos de imunofluorescência permitem confirmar se de fato anticorpos de diferentes isotipos IgG apresentam formas distintas de se ligarem à cápsula do fungo. Segundo achados anteriores, é esperado que IgG1 apresente padrão de fluorescência anular e que IgG3 apresente padrão puntiforme.

\subsubsection{Objetivo específico4 -Determinar o receptor por meio do qual os anticorpos} recombinantes medeiam sua função através de ensaios de fagocitose

Uma das principais funções imunitárias de anticorpos IgG contra patógenos encapsulados, como C. neoformans, é induzir a fagocitose por macrófagos através de interação com receptores Fc $\gamma$. Os quatro receptores Fc $\gamma$ conhecidos interagem com IgG1, IgG2a e IgG2b, mas segundo muitos autores, não com IgG3. A primeira sugestão de um receptor específico para IgG3 é de 1981, e resultados de testes de perda e ganho de função do grupo sugerem que esse receptor pode ser Integrina b-1. Todos esses testes, entretanto, foram feitos com 3E5. Assim, é necessário avaliar se a função opsonizante de outros anticorpos IgG3 (2H1 e 4-4-20) também é mediada por Integrina b-1. 


\title{
5. MATERIAIS E MÉTODOS
}

\subsection{SÍNTESE QUÍMICA DE GENES}

A sequência gênica da cadeia VL e VH do mAb 2H1 IgG1foi obtida no Protein Data Bank (PDB). De forma a produzir anticorpos para servirem de controle, obtivemos do mesmo banco de dados as sequências de aminoácidos dos domínios VH e VL do anticorpo murino 44-20, que se liga ao hapteno FITC(163-166). As sequências de aminoácidos foram convertidas em sequências nucleotídicas e otimizadaspor seleção de códons preferenciais (codon usage) para expressão em células de mamíferos. Essas sequências (Figura 8) foram sintetizadas quimicamente pela empresaGenScripte entregues em vetor de clonagem pUC57, de 2.710 pares de bases (pb) e marca de seleção para ampicilina (Figura 9). Os genes de cadeia pesada 2H1-VHe 4-4-20-VH vieram flanqueados pelo sítio de restrição AfeI/ Eco47III (5'AGCGCT 3'); os genes de cadeia leve 2H1-VL e 4-4-20-VL foram flanqueados por AgeI (5'ACCGGT 3') e BstAPI (5'GCAGATGCTGC3') (Figura 8).

Figura 8 - Sequência de genes 2H1 e 4-4-20 VH e VL.

\begin{abstract}
$>2 \mathrm{H} 1-\mathrm{VH}$
(AGCGC) JGCACCATGTATCGGATGCAGCTGCTGTCCTGTATCGCCCTGAGCCTGGCCCTGGTCACAAA CTCTGATGICAAACTGGTCGAAAGCGGGGGTGGCCTGGIGAAGCTGGGCGGATCACTGAAACTGAGCT GCGCCGCTTCCGGATTCACCTTTAGCTCCTACTTCCTGTCCTGGGTGCGACAGACACCCGAGAAGAGA CTGGAACTGGTCGCTACTATCAACAGCAATGGGGACAAGACCTACCACCCTGATACAATGAAAGGTCG GTTTACTATTTCTCGCGACAACGCAAAGAATACCCTGTATCTGCAGATGTCTAGTCTGAAAAGTGAGG ACACAGCACTGTACTATIGTGCCAGGAGAGATTCATCCGCATCTCTGTATITIGATTATTGGGGGCAG GGCACCACTCTGACTGTCTCCAGCGCI $>$ FITC-VH

AGCGCIGCCACCATGTACCGGATGCAGCTGCTGTCTTGTATTGCTCTGTCACTGGCTCTGGTCACTAA CTCTGAAGTCAAACTGGATGAAACTGGAGGAGGGCTGGTGCAGCCAGGTCGACCCATGAAGCTGTCTI GCGTCGCAAGTGGCTTCACCTITTCCGACTACTGGATGAACTGGGTGCGGCAGTCTCCCGAGAAGGGA CTGGAATGGGTGGCCCAGATCCGCAACAAACCTTACAACTACGAGACATACTACAGTGATTCAGTGAA GGGGAGGTTCACTATTTCAAGAGACGATAGCAAAAGCTCCGTGTATCTGCAGATGAACAATCTGAGAG TCGAAGACATGGGCATCTACTATTGTACCGGGAGTTACTATGGTATGGATTACTGGGGCCAGGGAACI AGCGTGACCGTCTCTAGCGCI

$>$ FITC-VL

(ACCGG)GCCACCATGTATCGGATGCAGCTGCTGTCCTGTATTGCCCTGTCCCTGGCCCTGGTGACTAA CTCAGACGICGTGATGACTCAGACCCCCIGICCCIGCCGTGICTCTGGGGACCAGGTICCATCI CTIGCCGGAGCTCCCAGAGTCTGGTCCACTCACAGGGGAACACCTACCTGCGCTGGTATCTGCAGAAG CCAGGCCAGTCTCCCAAGGTGCTGATCTACAAAGTCAGCAATAGGTTCTCCGGCGTGCCTGACAGGTT CAGCGGATCAGGGAGCGGTACCGATTTCACACTGAAAATTAGCCGAGTGGAGGCAGAAGACCTGGGAG TCTATTTCTGCTCCCAGTCTACTCATGTGCCTTGGACCTITGGCGGAGGGACAAAGCTGGAGATCAAA AGG[GCAGATGCTG]

$>2 \mathrm{H} 1-\mathrm{VL}$

ACCGGTGCCACCATGTATAGAATGCAGCTGCTGTCCTGTATTGCCCTGTCACTGGCTCTGGTCACAAA CTCCGATGTCGTGATGACTCAGACCCCACTGTCTCTGCCAGTGAGTCTGGGAGACCCCGCCTCTATCA GTTGCCGGAGCTCCCAGTCACTGGTCCACAGCAACGGTAATACCTACCTGCATTGGTATCTGCAGAAG CCCGGCCAGAGTCCTAAGCTGCTGATCTACAAAGTGTCCAACAGGTTCTCTGGAGTCCCCGACAAGTT TTCAGGCAGCGGATCCGGGACCGATTICACACTGAAAATTTCTAGAGTGGAGGCTGAAGATCAGGGGG TCTATTTTTGTTCACAGTCTACCCACGTGCCCTGGACATTCGGGGGGGGGACCAAGCTGGAAATCAAG AGGGCAGATGCTGC
\end{abstract}


Em vermelho estão marcadas as sequências de Kozak para expressão gênica em mamímefos. Em azul nas sequências VH estão os sítios de restrição AfeI; e em VL a montante está o sítio AgeI e a jusante o sítio BstAPI. As sequências gênicas estão no sentido 5' -3 '.

Figura 9 - Mapa do vetor pUC57 (GenScript) carreador dos insertos 2H1 e 4-4-20 VH/VL

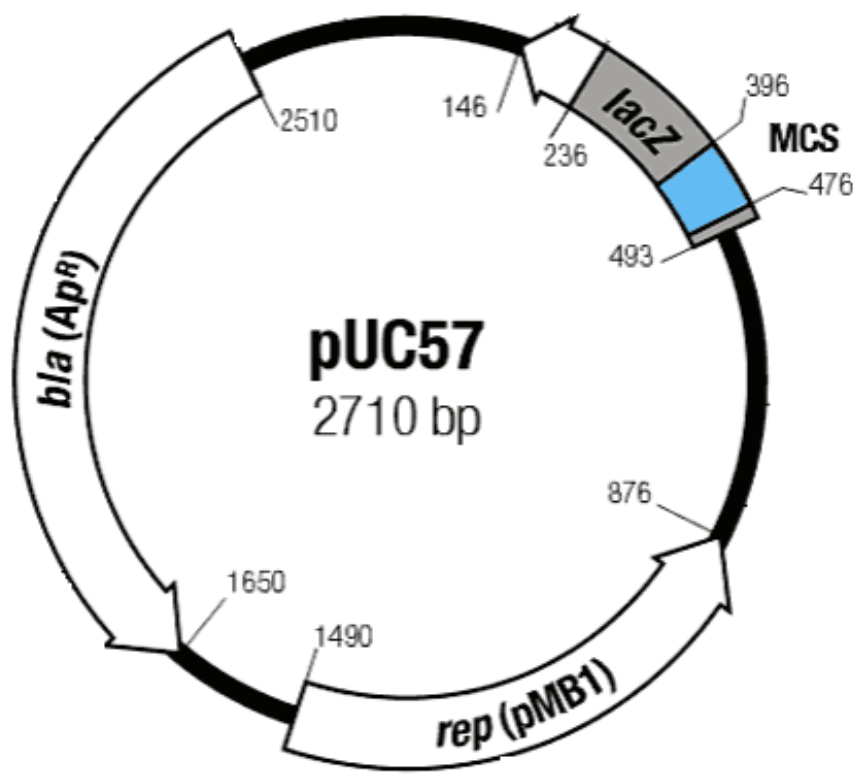

Em azul está representado o sítio de clonagem múltipla. Do lado oposto, o gene bla $\left(\mathrm{Ap}^{\mathrm{r}}\right)$, que confere resistência à ampicilina.

\subsection{CLONAGEMDE VH E VL EM VETORES DE EXPRESSÃO.}

Os vetores pUC57 foram transformados em E. coli DH5 $\alpha$ eletrocompetentes (New England Biolabs) e plaqueados em meio Luria Bertani (LB) sólido com ampicilina (100 $\mu \mathrm{g} / \mathrm{mL}$ ). As colônias isoladas foram inoculadas em meio LB líquido por até $16 \mathrm{~h}$ a $37^{\circ} \mathrm{C}$ sob agitação. A purificação dos plasmídeos por lise alcalina foi realizada,ora por minipreparaçãocaseira adaptada de Sambrook(167),ora por “GenElute ${ }^{T M}$ HP Plasmid Miniprep Kit" (Sigma Life Sciences). A qualidade da purificação foi avaliada por eletroforese em gel de agarose a $1 \%$ e a quantificação pelo método fluorimétricoQubit ${ }^{\mathrm{TM}} d s D N A$ BR Assay (Invitrogen). Para clonagem, os plasmídeospUC57 VH e os plasmídeos contendo cadeia constante pesada pFUSE-CHIg-mG1 (Invivogen) (Figura 10), pFUSE-CHIg-mG3 (Invivogen) (Figura 11) foram digeridos por AfeI/ Eco47III (New England Biolabs); enquanto os pUC57 VL e plasmídeo de cadeia constante kappa pFUSE-CHIg-mK (Invivogen) (Figura 12) foram digeridos por AgeI e BstAPI (New England Biolabs). Os insertos VH liberados de pUC57 foram eluídos, purificados porlllustra GFX PCR DNA and Gel Band Purification Kit (GE 
Healthcare) e quantificados por Qubit ${ }^{\mathrm{TM}} d s D N A$ BR Assay (Invitrogen). O DNA clivado em extremidades cegas foi defosforilado usando Antartic phosphatase (New England Biolabs). Os insertos VH foram ligados aos vetores pFUSE-CHIg-mG1 e pFUSE-CHIg-mG3; e os VL ao pFUSE-CHIg-mK por uma noiteà temperatura ambiente, utilizando T4 DNA ligase (Thermo Scientific ${ }^{\mathrm{TM}}$ ) e proporção inserto:vetor 1:1, 3:1,6:1. Os vetores ligados foram transformados em E. coli DH5 $\alpha$ eletrocompetentes (New England Biolabs) e plaqueados em meio LB sólido com Zeocina ${ }^{\mathrm{TM}}$ Invitrogen $(25 \mu \mathrm{g} / \mathrm{mL})$ para seleção de clones de cadeia pesada; e com Blasticidina $(50 \mu \mathrm{g} / \mathrm{mL})$ para seleção de clones de cadeia leve. Foi feito préinóculo das colônias em seleção com os mesmos antibióticos descritos para plaqueamento, sendo realizado posteriormente minipreparação, eletroforese em gel de agarose $1 \%$ e quantificação fluorimétrica.

Figura 10 - Mapa do vetor de expressão pFUSE-CHIg-mG1 (Invivogen) para clonagem dos insertos $\mathrm{VH}$.

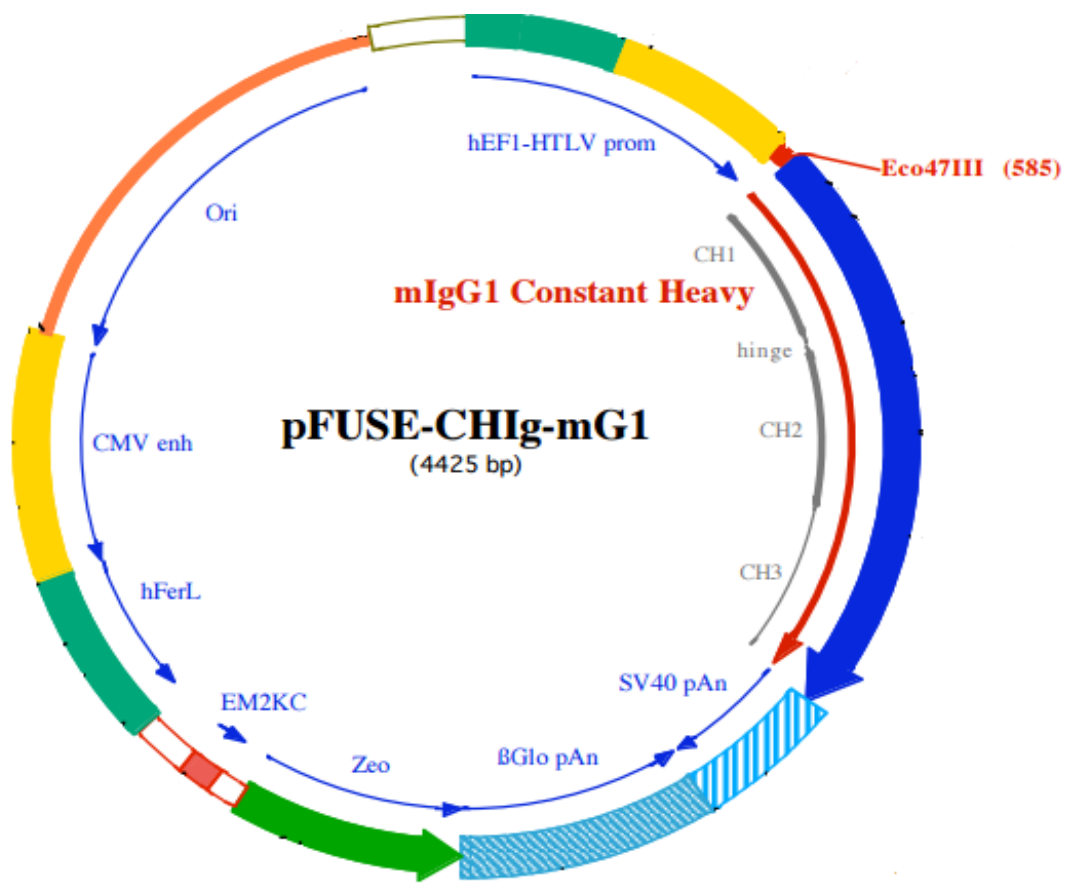

Em vermelho, o sítio de restrição Eco47III/AfeI (585). 
Figura 11 - Mapa do vetor de expressão pFUSE-CHIg-mG3 (Invivogen) para clonagem dos insertos $\mathrm{VH}$.

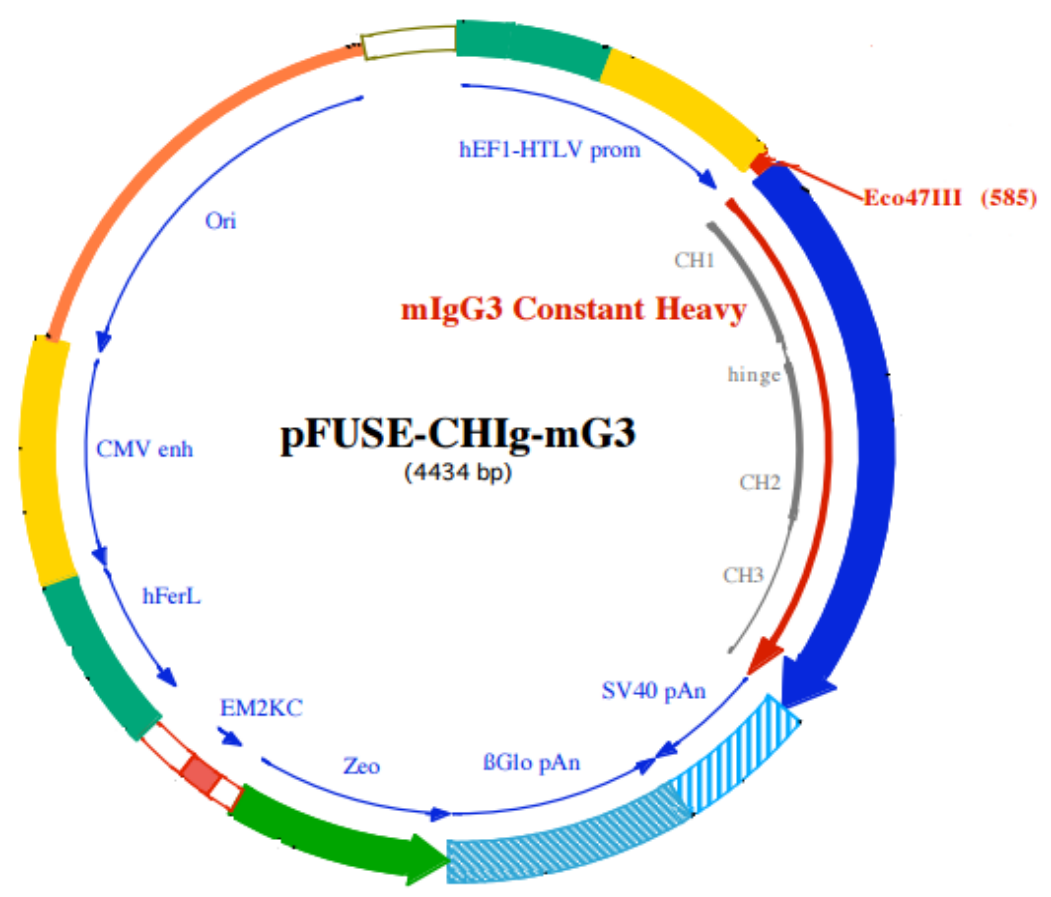

Em vermelho, o sítio de restrição Eco47III/AfeI (585).

Figura 12 - Mapado vetor de expressão pFUSE2-CLIg-mk (Invivogen) para clonagem dos insertos VL.

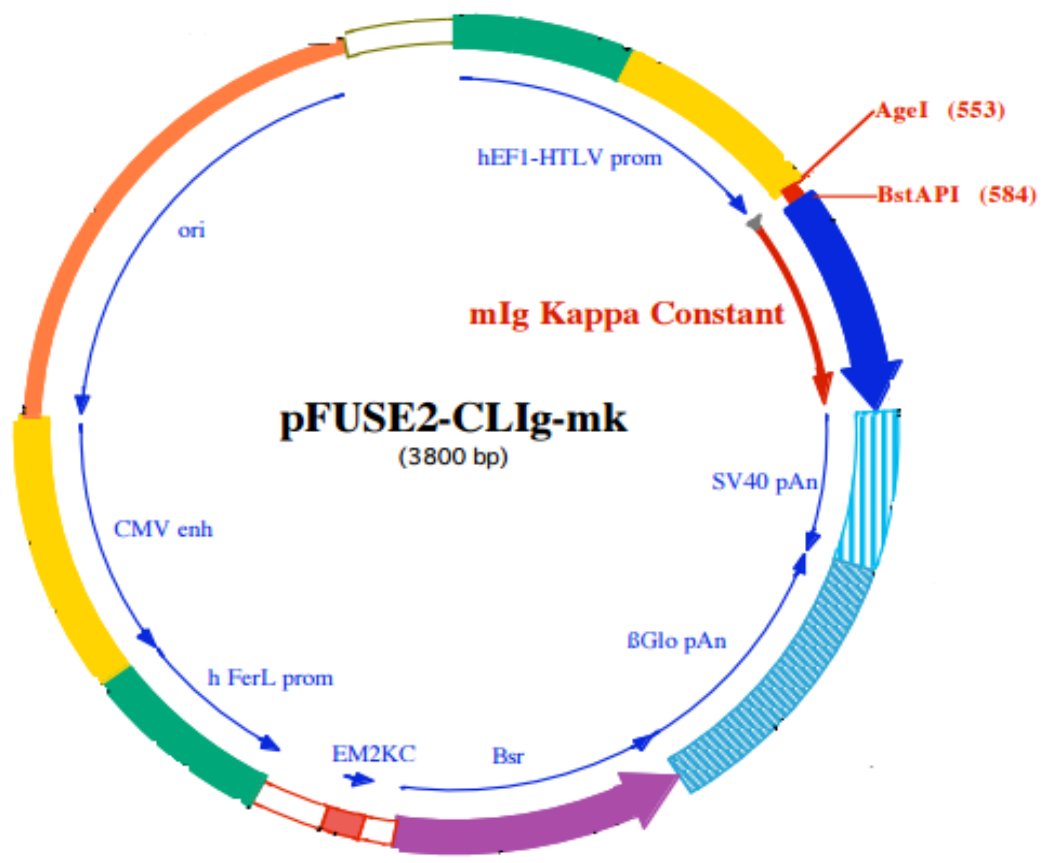

Em vermelho, os sítios de restrição AgeI (553) e BstAPI (584). 


\subsection{CONFIRMAÇÃO DE CLONES POR DIGESTÃO, PCR E SEQUENCIAMENTO.}

Os clones 2H1-VH+CHIg-mG1, 2H1-VH+CHIg-mG3, 2H1-VL+CLIg-mK, 4-4-20VH+CHIg-mG1，4-4-20-VH+CHIg-mG3，4-4-20-VL+CLIg-mK foram confirmados após digestão com as mesmas enzimas de clonagem, por visualização em gel de agarose dos vetores pFUSE-CHIg-mG1 (4.425 pb), pFUSE-CHIg-mG3 (4.434 pb) e pFUSE-CHIg-mK (3.800 pb); e de seus insertos 2H1-VH (435 pb), 4-4-20-VH (429 pb), 2H1-VL (422 pb) e 44-20-VL (422 pb). A confirmação da clonagem das regiões VH e VL foi feita por Reação em Cadeia da Polimerase (PCR) utilizando a enzimaPyroStart ${ }^{\mathrm{TM}}$ Fast PCR Master Mix (2X) (Fermentas, Thermo Scientific),iniciadores senso que alinham a região a montante do promotor em comum a todos os vetores, e iniciadores anti-senso específicos para região 3' terminal de cada inserto(Exxtend) (Tabela 3). Os clones confirmados por PCR foram sequenciados em ABI 3130xl (Applied Biosystems)no Centro de Genômica de Alto Desempenho do Distrito Federal, situado na Universidade Católica de Brasília (UCB), e assequências foram analisadas pelo programa PHPH (MegaBACE ou ABI), Nucleotide BLAST (NCBI) e Expasy Translate (SIB).

Tabela 3- Iniciadores utilizados para amplificação e sequenciamento dos insertos $2 \mathrm{H} 1$ e 4-4$20 \mathrm{VH}$ e VL.

\begin{tabular}{|c|c|}
\hline Nome & Sequência (nt) 5'-3' \\
\hline pFUSE-seq-Forward & TGCTTGCTCAACTCTACGTC \\
\hline 2H1-VH-Reverse & ATGCGGATGAATCTCTCCTG \\
\hline 2H1-VL-Reverse & CTGATCTTCAGCCTCCACTC \\
\hline 4-4-20-VH-Reverse & TAGATGCCCATGTCTTCGAC \\
\hline 4-4-20-VL-Reverse & TCTGCCCTTTTGATCTCCAG \\
\hline
\end{tabular}

\subsection{PRODUÇÃO DE ANTICORPOS RECOMBINANTES}

Células de Ovário de Hamster Chinês (CHO-K1 ATCC® CCL-61 ${ }^{\mathrm{TM}}$ ) e de Mieloma Murino Não Secretor de Imunoglobulina (NSO PTA-3570)em suspensão foram mantidas na confluência de $4-8 \times 10^{5}$ células por $\mathrm{mL}$ a $37^{\circ} \mathrm{C}$ e $5 \%$ de $\mathrm{CO}_{2}$.Ambas foram co-transfectadas com plasmídeos codificando cadeia pesada e cadeia leve dos anticorpos com dois reagentes de transfecção Lipofectamina 2000 (Invitrogen) e K2 (Biontex) na proporção DNA ( $\mu \mathrm{g})$ : 
reagente $(\mu \mathrm{L})$ 1:1 a 1:5. Transfecção estável foiobtida após 2-3 semanas em seleção com Zeocina $(2 \mathrm{mg} / \mathrm{mL})$ e Blasticidina $(10 \mu \mathrm{g} / \mathrm{mL})$. Para aumentar a produtividade de anticorpos após a transfecção e seleção, foi realizada diluição limitante de clones, para mais uma vez selecionar os mais produtivos, sendo estes escalonados de placa com 96 poços para placas com 24 poços, 6 poços, placas de $100 \mathrm{~mm}$ e,por fim,garrafas de $175 \mathrm{~cm}^{2}$. As células NSO, após avaliação de sua produtividade, passaram a ser as únicas utilizadas, sendo adaptadasde crescimento em GIBCO ${ }^{\circledR}$ Dulbecco's Modified Eagle Medium(DMEM)1X (Life technologies) com $10 \%$ de Soro Fetal bovino (SFB) inativado por calor, para crescimento em meio GIBCO $^{\circledR} C D$-hybridoma $A G T^{\mathrm{TM}} 1 \mathrm{X}$ (Life technologies) filtrado em membrana de hidrofílica de polietersulfona 0,22 $\mu \mathrm{m}$ (Kasvi). Alíquotas da diluição de clones foram congeladas em $10 \%$ de dimetilsulfóxido (DMSO)sobre o volume final de SFB. O sobrenadante de cultura celular proveniente de cada anticorpo foi colhido em pool e armazenado a $-20^{\circ} \mathrm{C}$.Em tentativas posteriores, os clones que apresentaram melhor produtividade foram descongelados e mantidos para escalonamento e coleta de sobrenadante para testes. Ao final do projeto foi possível manter o cultivo das células NSO sob agitador e escalonar o crescimento para erlenmeyers de plásticode $1000 \mathrm{~mL}$ (Corning). Durante os procedimentos de subcultura celular, foi realizado teste de viabilidade com o corante vital azul de tripano 1X(SigmaAldrich). As amostras foram então ultrafiltradas em sistemaAmicon® (Millipore)com membranas de 10 kDasob pressão constante de nitrogênio.

\subsection{PURIFICAÇÃO DE ANTICORPOS}

Diferentes métodos cromatrográficos foram testados para purificação e concentração dos sobrenadantes dos melhores clones produtores de anticorpos, sendo executados em colaboração com a pesquisadoraDra. Verenice Adriana Paredes Hernandez. Os métodos utilizados foram: Cromatografia de Afinidade com coluna de proteína G“HiTrap Protein G HP, 1 mL" (GE,Life sciences),Exclusão Molecular com coluna "HiLoad 16/600 Superdex 75 pg, $120 \mathrm{~mL}$ " (mesmo fabricante), TrocaAniônica e Catiônica com colunas "HiTrap SP HP, $1 m L ", " H i T r a p$ Capto $Q 1 \mathrm{~mL}$ "(troca aniônica forte), "HiTrap Capto MMC"(ligante multimodal, troca catiônica fraca) e "HiTrap Capto DEAE, $1 m L$ "(troca aniônica fraca),HiScreen Capto DEAE(10 mL), Ultrafiltração com membranas de diferentes tamanhos de poro (3-100 kDa) em tubos Amicon (Millipore) e Vivaspin ${ }^{\circledR}$ (GE Healthcare Life sciences).

Antes de cada purificação as amostras foram filtradas em membrana de fluoreto de polivinilideno (PVDF) 0,22 $\mu \mathrm{m}$. As amostras foram filtradas antes do armazenamento e 
sempre mantidas a baixa temperatura (aproximadamente $4^{\circ} \mathrm{C}$ ). Antes e depois de cada procedimento de purificação foram coletadas alíquotas para, posteriormente, estimara perda de anticorpos ao longo dos procedimentos.

\subsubsection{Purificação de anticorpos por dietilaminoetil sefarose (DEAE)}

A melhor recuperação foi obtida portroca aniônicacom matriz positivamente carregada, composta dedietilaminoetilanol covalentemente ligada a sefarose (DEAE) e associada a dextrano.A metodologia foi realizada emcromatógrafo Akta Avant 25 e programa Unicorn 6.2 (ambos GE Healthcare Life Sciences) no Centro de Ciências Genômicas e Biotecnologia (UCB). A coluna “HiScreen Capto DEAE”suporta 4,7 mL, apresenta dimensão de 0.77 x $10 \mathrm{~cm}$, capacidade de ligação $>90 \mathrm{mg} / \mathrm{mL}$. Os limites de pressão $(0,8 \mathrm{Mpa})$ e taxa de fluxo $(1,2 / \mathrm{mL})$ foram respeitados, conforme as recomendações do fabricante (168). A faixa de pH da matriz é de 2-9 e o tampão de equilíbrio e de eluição utilizado foi o Tris-HCl $20 \mathrm{mM}$ pH 8 e Tris- $\mathrm{HCl} 20 \mathrm{mM}+1 \mathrm{M}$ Nacl pH 8, respectivamente.O modo de purificação utilizado foi o não ligante, onde anticorpos não se ligam à coluna e são recuperados no flow-through, enquanto os contaminantes se ligam a coluna e são lavados em condições de eluição. O flowthroughfoi coletado e armazenado a $4^{\circ} \mathrm{C}$.

\subsubsection{Precipitação de anticorpospor solução saturada com sulfato de amônio (SAS)}

As amostras purificadasforamprecipitadas com solução saturada de sulfato de amônio(4,84 M, pH 7,45), por adição do sal ao flow-throughsob constante agitação até alcance da concentração de 37 a 50\%. As soluções foram centrifugadas e os precipitadosforamlavados com tampão fosfato salino10X (PBS)resfriado, sendo o procedimento repetido até ressuspensão total dos precipitados. Uma alíquota do concentrado e do lavado foi coletada para análises posteriores. As ressuspensões foram dialisadas e concentradas em Vivaspin $^{\circledR}$ 20, com limite de peso molecular (MWCO) de 10 (GEHealthcare Life sciences) para volume final de aproximadamente $5 \mathrm{ml}$.

\subsubsection{Purificação de anticorpos por cromatografia de exclusão molecular.}

Para remoção do sal residual e de outros possíveis contaminantes de massa molecular menor que $70 \mathrm{kDa}$,as amostras foram purificadas por exclusão molecularusando HiLoad 16/600 Superdex 75 pg, novamente no cromatógrafoAkta Avant 25. A coluna possui matriz de dextrano altamente ligada à agarose, com faixa de separação de moléculas de $30 \mathrm{kDa}$ a 70 
kDa (169).Foi usado tampão PBS 1x pH 6.8 para equilíbrio e eluição; e a taxa de fluxo (1 $\mathrm{mL} / \mathrm{min}$ ) e limites de pressão da coluna foram seguidos conforme as recomendações do fabricante. As amostras foram coletadas apenas quando as frações geraram picos de absorção de luz ultravioleta entre $260 \mathrm{~nm}$ a $280 \mathrm{~nm}\left(\mathrm{UV}_{260}-\mathrm{UV}_{280}\right)$. Os anticorpos foram concentradospara o volume final de $1 \mathrm{ml}$ e armazenados a $4^{\circ} \mathrm{C}$.

\subsection{QUANTIFICAÇÃO DE ANTICORPOS}

\subsubsection{Ensaio imunoadsorvente ligado a enzima}

Alíquotas obtidas antes, durante e após a purificação tiveram sua concentração testada por ELISA indireto. Placas de poliestireno de 96 poços foram revestidas com GXM ou com albumina de soro bovino (BSA) conjugado a FITC por $1 \mathrm{~h}$ a $37^{\circ} \mathrm{C}$ ou durante a noite a $4^{\circ} \mathrm{C}$, para detecção de anticorpos $2 \mathrm{H} 1$ e 4-4-20, respectivamente. Então, as placas foram bloqueadas com BSA $1 \%$ por $1 \mathrm{~h}$ à mesma temperatura e lavadas $3 \mathrm{x}$ com PBS 1x com tween20 a $0.05 \%$. À placa com GXM foram adicionadas amostras sem diluir e diluídas com PBS 1X, assim como o padrão (mAb 18B7 IgG1) diluído em série 1:2 (com faixa de diluição entre $2 \mu \mathrm{g}$ a $0.0152 \mu \mathrm{g}$ ). A placa com BSAtambém teve adição de amostras diluídas da mesma forma, no entanto não havia anticorpo padrão para detecção para tornar possível a quantificação dos anticorpos teste. Após as placas serem incubadas e lavadas novamente, o anticorpo secundário de cabra anti-IgG de camundongo conjugado à fosfatase alcalina (1:1000 em BSA1\%) foi adicionado e incubado. A placa foi lavada novamente e incubada por até $30 \mathrm{~min}$ com o substrato p-nitrofenil fosfato ( $\mathrm{PNPP}$ ) em solução tampão. A reação é revelada por medida de densidade óptica (DO) a $405 \mathrm{~nm}$. A concentração foi estabelecida pelo cálculo de coeficiente de correlação de Pearson, tendo a equação da reta sido determinada mediante a regressão linear simples,realizado pelo programa Excel (Microsoft).

\subsubsection{Métodos espectrofotométricos}

Os anticorpos foram também quantificados pelo método nanofotométrico, utilizandoNanoPhotometer $^{\mathrm{TM}}$ Pearl (Implen), o qual se baseia na detecção de absorção de $\mathrm{UV}_{280}$ e requer um pequeno volume de amostra. Esse espectro de absorção é característico de aminoácidos como tirosina e triptofano(aromáticos) e cisteína. A partir desse dado, a lei de Lambert-Beer (leva em consideração o caminho óptico e o coeficiente de absorção/extinção molar) pôde ser aplicada para determinar a concentração de proteína da amostra. A massa molecular e coeficiente de extinção molar obtidospelo Protparam (ExPASy) para cada 
anticorpo são: 2H1 IgG1 (154.947,2 Da/216.895 $\mathrm{M}^{-1} \mathrm{~cm}^{-1}$ ou 1,4 g/L), 2H1 IgG3 (156.064,8 $\mathrm{Da} / 222.605 \mathrm{M}^{-1} \mathrm{~cm}^{-1}$ ou 1,426 g/L), 4-4-20 IgG1 (155.575,7 Da/250.815 $\mathrm{M}^{-1} \mathrm{~cm}^{-1}$ ou 1,612 g/L) e 4-4-20 IgG3 (156.693,3 Da/256.525 $\mathrm{M}^{-1} \mathrm{~cm}^{-1}$ ou 1,637 g/L). A quantificação pelo método foi feita apenas em amostras purificadas, a fim de evitar leitura inespecífica por contaminantes que apresentam forte absorbância de UV (ácidos nucléicos, detergentes).Alternativamente, as amostras foram quantificadas por fluorimetria no equipamentoQubit ${ }^{\circledR}$ Protein Assay (Life Technologies).

\subsection{ELETROFORESE EM GEL DE POLIACRILAMIDA COM DODECIL SULFATO DE SÓDIO (SDS-PAGE)}

A confirmação da massa molecular, purificação e concentração dos anticorpos foi estimadapela técnica de SDS-PAGE usando Mini-PROTEAN Tetra cell (Bio-Rad) e o protocolo seguiu as recomendações do fabricante(170).Depois de misturadas ao tampão desnaturante e fervidas por 5 minutos, até $20 \mu \mathrm{L}$ total (amostra + tampão) foram aplicados no gel polimerizado. O marcador de peso molecular Broad Range (Bio-Rad) nãocorado foi aplicado diretamente no gel, sem ferver, assim como as amostras em condição nãodesnaturante.As proteínas foram separadas pela massa molecular e migração de carga em gel carregador a $5 \%$ e gel separador a $10 \%(20 \mathrm{kDa}-300 \mathrm{kDa}) \mathrm{ou} 12 \%(10 \mathrm{kDa}-200$ kDa)utilizando os reagentes em comum: SDS 10\%, persulfato de amônio $10 \%$, N,N,N',N'tetrametiletilenodiamina (TEMED), bis-acrilamida 30\% e água destilada. Tampão Tris-HCl 1 M pH 6,8 para gel carregador e Tris- $\mathrm{HCl} 1,5 \mathrm{M}$ pH 8,8 para gel separador de diferentes pHs foi utilizado para realização de eletroforese em sistema de géis descontínuo. A corrida do gel foi realizada em imersão em tampão Tris-glicina $1 \mathrm{X} \mathrm{pH} \mathrm{8,8a} 15 \mathrm{~V}$ por 20 minutos e $170 \mathrm{~V}$ para o resto da corrida. O gel foi corado com comassie Brilliant Blue R250/G250(Sigma-Aldrich) e algumas vezes com sulfato de prata (Sigma-Aldrich) (171).

\subsection{ENSAIOS FUNCIONAIS DE ANTICORPOS}

A funcionalidade dos anticorpos recombinantes foi testada pelos métodos de imunofluorescência e fagocitose. Os primeiros testes foram feitos com amostras de sobrenadante de células transfectadas antes da seleção com antibiótico.Os ensaios tiveram participação ativa do Dr. André Nicola, que possui expertise na área e já vem contribuindo com o grupo desde 2011. 


\subsubsection{Ensaio de fagocitose com células J774}

Esse experimento foi realizado para determinar se os macrófragos da linhagem J774.1,(ATCC® TIB-67 ${ }^{\mathrm{TM}}$ ) originados de sarcoma de célula reticular de tecido peritoneal de camundongos BALB/c, foram capazes de fagocitar C. neoformans por opsonização dos anticorpos recombinantes. O ensaio de fagocitose foi realizado em placas de 96 poços contendo macrófagos (densidade por poço: $5 \times 10^{4}$ ). A condição de cultivo e incubação das células foi com DMEM 1X (Gibco) suplementado com SFB 10\%, meio GIBCO ${ }^{\circledR}$ NCTC-109 e $1 \%$ de aminoácido não essencial, a $37^{\circ} \mathrm{C}, 5 \%$ de $\mathrm{CO}_{2}$ por $16-24$ h.No segundo dia de alguns experimentos, foram adicionados:anticorpos de bloqueio de receptor complemento (anti-

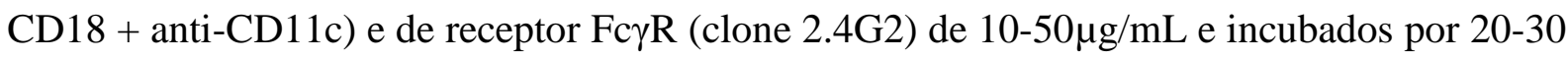
min. Células sem anticorpos de bloqueio foram mantidas para validação do experimento. Foram também adicionadasas opsoninas2H1-IgG1 e IgG3 recombinantes (10 $\mu \mathrm{g} / \mathrm{mL})$ e 18B7, como controle positvo; e suspensão dos sorotipos A (H99) e D (24067) (cedidos pelo Dr. Arturo Casadevall)do fungo com relação macrófago: $C$. neoformans 1:1 a 1:2 por $2 \mathrm{~h}$. Células contendo nenhum anticorpo foram mantidas para controle negativo. As células foram fixadas 30 min com metanol $-20^{\circ} \mathrm{C}$, lavadas três vezes com PBS $1 \mathrm{X}$ e coradas por Giemsa 1:20. As células foram analisadas em microscópio invertido Zeiss AxioObserver Z1, sendo contadas,no mínimo, 100 células/poço. A porcentagem de fagocitose foi calculada com o número de macrófagos contendo um ou mais $C$. neoformans, dividido pelo total de macrófagos contados. Em alguns casos, células CHO-K1, que apresentaram função fagocítica em experimentos prévios do grupo de pesquisa (172), também foram utilizadas no ensaio funcional dos anticorpos.

A fagocitose de BSA conjugada a FITC (hapteno) e a fluoróforo sensível a $\mathrm{pH}$ (pHrodo) mediada por anticorpos 4-4-20 foi testada de forma semelhante a descrita (173).O BSA foi marcado com FITC e pHrodo, usando concentração alta suficiente do antígeno FITCpara resultar em alto número de corantes por molécula de BSA, possibilitando que anticorpos realizem ligação cruzada e formação de imunocomplexos. O pHrodo é nãofluorescente em $\mathrm{pH}$ neutro ou alcalino, mas emite fluorescência vermelha em ambientes ácidos. Anticorpos 4-4-20-IgG1 e 4-4-20-IgG3 foram incubados com BSA marcado com FITC e pHrodo para formar imunocomplexos. Os imunocomplexos foram incubados com células $\mathbf{J} 774$ pré-tratadas ou não com anticorpos de bloqueio anti-Fc $\gamma \mathrm{R}$. A fagocitose foi interpretada como positiva pela porcentagem de células que se tornaram vermelhas, sugerindo 
que o pHrodo foi translocado do ambiente neutro do meio para o interior de compartimento endolisossomal. Vários controles foram feitos para validação do método.

Os testes de fagocitose foram avaliados usando o teste de comparações múltiplas de análise de variância (ANOVA)Newman-Keuls Multiple Comparison Test pelo programa Graphpad Prism6 (GraphPad Software, Inc.).

\subsubsection{Avaliação do padrão de ligação IgG-GXM por imunofluorescência indireta}

O padrão capsular dos anticorpos $2 \mathrm{H} 1$ foi examinado por microscopia de epifluorescência com deconvolução (24). Células H99 e 24067 crescidas durante a noite,foram centrifugadas e lavadas três vezes com PBS $1 \mathrm{X}$ para contagem final entre $10^{6} \mathrm{e}$ $10^{7} / \mathrm{mL}$. As mesmasforam incubadas com o anticorpo primário em concentrações de 1 a 10 $\mu \mathrm{g} / \mathrm{mL}$ por $1 \mathrm{~h}$ a $37^{\circ} \mathrm{C}$ sob agitação e depois de lavadas duas vezes com PBS 1X.Em seguida foram incubadas com anticorposecundário de cabra anti-IgG de camundongo conjugado

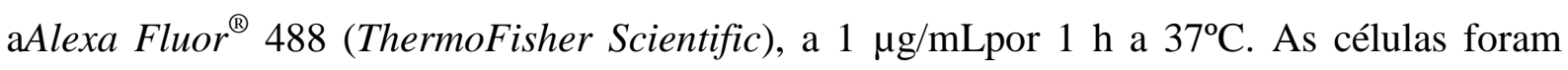
lavadas novamente com PBS. Também foram utilizados anticorpos secundários anti-IgM conjugados a Alexa Fluor ${ }^{\circledR} 488$ (ThermoFisher Scientific) para detecção de anticorpos primários $12 \mathrm{~A} 1$ e 13F1, utilizados como controle positivo. As células foram imobilizadas em lâmina com meio de montagem ProLong ${ }^{\circledR}$ Gold Antifade Mountant (ThermoFisher). As amostras foram visualizadas em microscópio de epifluorescência Zeiss Axio Observer Z1 naobjetiva de 63X (NA 1,4), câmera AxioCam MRccom CCD resfriado e estágio motorizado para coleta de séries de imagens ao longo do eixo Z. As séries de imagens resultantes foram processadas por meio de algoritmo de deconvolução iterativo com o programaZeiss ZENPRO e reconstruídas tridimensionalmente com os programas ImageJ e VOXX 2. Para edição de imagens foram utilizados os programas Photoshop CS6 e Illustrator CS6 (Adobe).

\subsection{SUBSTITUIÇÃO DE FRAGMENTOS CH1 E DE DOBRADIÇA ENTRE 2H1-IGG1 E 2H1-IGG3 POR SÍNTESE GÊNICA E CLONAGEM.}

A fim de identificar o mecanismo pelo qual a porção constante da cadeia pesada afeta o paratopo do anticorpo, planejamos uma série de anticorpos nos quais fragmentos da sequência de um isotipo foram substituídos pela sequência correspondente do outro (Figura 13). Sequências dos domínios $\mathrm{CH} 1$ edobradiçade $\operatorname{IgG} 1$ e IgG3 murino disponíveis no banco de dados International ImMunoGeneTics Information System (IMGT) foram estudadas com o objetivo de gerar recombinação de DNA entre frações dos vetores pFUSE-CHIg-mG1 e 
pFUSE-CHIg-mG3 clonados com 2H1. Para eleição das frações, foi realizado alinhamento por ClustalW2(EMBL-EBI) entre as sequências de aminoácidos da região CH1 de IgG1 e IgG3.As sequências que mais variaram encontravam-se distribuídas em três grupos para anticorpos IgG1 e para IgG3. Desta forma, sequências desses três grupos foram definidas $\begin{array}{llll}\text { como fragmentos: } & \text { F1 } & \text { (KTTPPSVYPLAPGSAAQTNSM), } & \text { F2 }\end{array}$ $\begin{array}{llll}\text { (TWNSGSLSSGVHTFPAVLQSD) } & \text { e } & \text { F3 }\end{array}$ (LYTLSSSVTVPSSPRPSETVTCNVAHPASSTKVDKK) de $\quad \mathrm{CH} 1 \quad \mathrm{IgG} 1 ; \quad \mathrm{F} 1$ $\begin{array}{llllll}\text { (TTTAPSVYPLVPGCSDTSGSS), } & \text { F2 } & \text { (KWNYGALSSGVRTVSSVLQSG) } & \text { e } & \text { F3 }\end{array}$ (FYSLSSLVTVPSSTWPSQTVICNVAHPASKTELIKR) de CH1 IgG3. Fragmentos CH1 IgG1 foram sintetizados quimicamente (Genewiz) e clonados (pela mesma empresa) em vetor pFUSE-CHIg-mG3 recombinado com região variável pesada. De forma semelhante foi realizada substituição das sequências de dobradiça, sendo a sequência de dobradiça de IgG3 (EPRIPKPSTPPGSSCP) substituída pela dobradiça de IgG1 (VPRDCGCKPCICT) e viceversa. Ao final, foram produzidos cinco vetores recombinados: F1-CH1-2H1 IgG3, F2-CH12H1 IgG3, F3-CH1-2H1 IgG3, D-CH1-2H1 IgG3 e D-CH1-2H1 IgG1.

Figura 13 - Substituição de fragmentos CH1 e dobradiça entre 2H1-IgG1 e 2H1-IgG3.

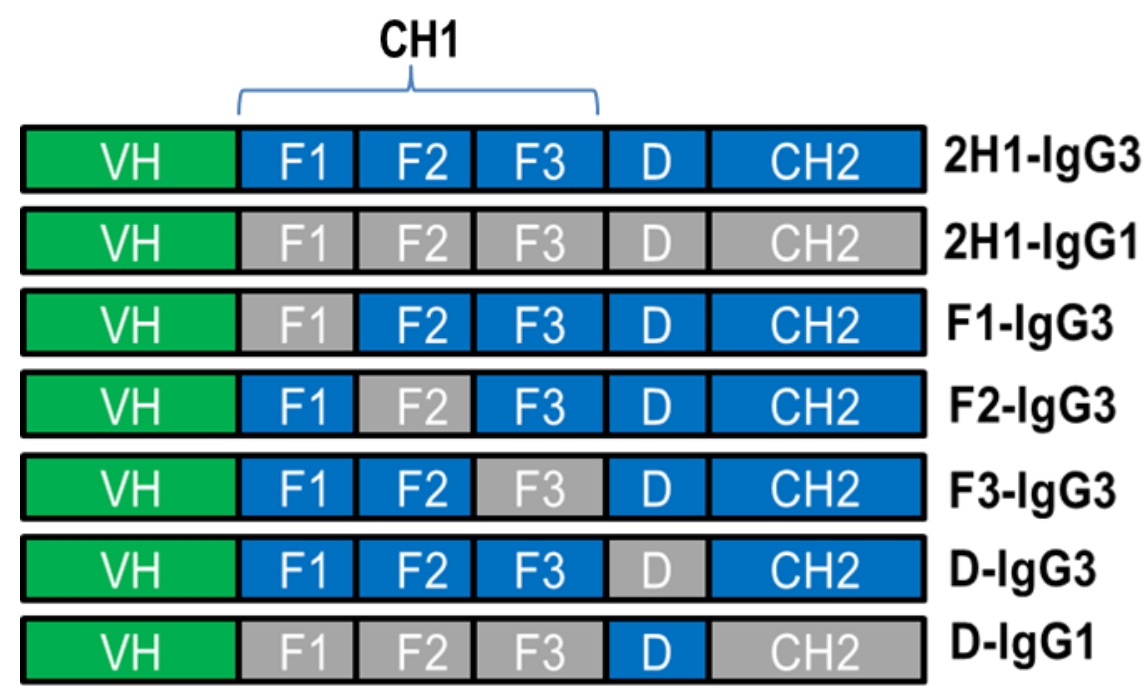

Região gênicas próximas a CH1 de vetores que originam anticorpos IgG1 e IgG3. A cor azul e cinza representa sequências de 2H1-IgG3e de 2H1-IgG1, respectivamente. 


\section{RESULTADOS}

\subsection{CLONES2H1/4-4-20E ANÁLISE DE SEQUÊNCIAS}

As clonagens das regiões variáveis VH e VL do gene 2H1 e 4-4-20 em vetores pFUSE-CHIG-mG1, pFUSE-CHIG-mG3, pFUSE-CLIG-mK (Invivogen) foram obtidas. Os genes de cadeia variável pesada, 2H1 VH e 4-4-20 VH, foram digeridos de pUC57(GenScript) pelos sítios de restrição AfeI/ Eco47III (New England Biolabs), apresentando bandas de 435 pb (2H1 VH), 429 pb (4-4-20 VH) e 2.710 pb (pUC57) em eletroforese em gel de agarose $1 \%$ revelado com brometode etídeo sob luz UV. Já os genes de cadeia leve, 2H1 VL e 4-4-20 VL, foram digeridos de pUC57 pelos sítios de restrição AgeI e BstAPI (New England Biolabs), gerando bandas de 422 pb (2H1 VL e 4-4-20 VL) e 2.710 pb (pUC57) (Figura 14A).

Os insertos 2H1 VH e 4-4-20 VH foram ligados aos vetores pFUSE-CHIG-mG1 (4,425 bp), pFUSE-CHIG-mG3 (4,434 bp), gerando DNA recombinante de 4.860 pb (2H1 $\mathrm{VH}+\mathrm{pFUSE}-\mathrm{CHIG}-\mathrm{mG} 1), 4.869 \mathrm{pb}(2 \mathrm{H} 1 \mathrm{VH}+\mathrm{pFUSE}-\mathrm{CHIG}-\mathrm{mG} 3), 4.854 \mathrm{pb}$ (4-4-20 VH + pFUSE-CHIG-mG1) e 4.863 pb (4-4-20 VH + pFUSE-CHIG-mG3). 2H1 VL e 4-4-20 VL foram ligados ao vetor pFUSE-CLIG-mK (3.800 pb), gerando DNA recombinante de 4.222 $\mathrm{pb}(2 \mathrm{H} 1 \mathrm{VL}+$ pFUSE-CLIG-mK e 4-4-20 VL + pFUSE-CLIG-mK)(Figura 14B). Os seis vetores tiveram seus números de cópias aumentados por transformação e cultivo em $E$. coli DH5aeletrocompetentes (New England Biolabs) sob seleção com os antibióticos Zeocina (dos transformados pFUSE-CHIG de cadeia pesada) e Blasticidina (transforamados pFUSE-CLIG de cadeia leve), apresentando concentração média de DNA recombinante entre 50 e 200 ng/ $\mu \mathrm{L}$ após minipreparação(Figura 14B) e quantificação por Qubit dsDNA BR Assay (Invitrogen).

A recombinação dos clones foi confirmada por PCR usandoiniciadores que se anelaram a região promotora dos vetores e terminal dos insertos, gerando amplicons de 549 pb (2H1 VH), 543 pb (4-4-20 VH), 536 pb (2H1 VL e 4-4-20 VL) (Figura 14C-F).

Ao total foram obtidos 27 clones com amplificação do inserto confirmada, sendo 5, 8, 3, 1, 3 e 7 para 2H1 VL mK, 2H1 VH mG1, 2H1 VH mG3, 4-4-20 VL mK, 4-4-20 VH mG1 e 4-4-20 VH mG3, respectivamente. Desses clones, apenas alguns representantes de cada tipo foram sequenciados e apresentaram qualidade de sequência nucleotídica acima de 20 pb para sequências maiores do que 100 pb (Tabela 4) e identidade de aminoácidos da cadeia variável 
dos insertos $100 \%$ compatível com adas sequências originais(Tabela 5), evidenciados pelos programas PHPH e nucleotide/protein BLAST, respectivamente.

Figura 14- Clonagem de 2H1 e 4-4-20 em vetores pFUSE visualizados em gel de agarose a $1 \%$.

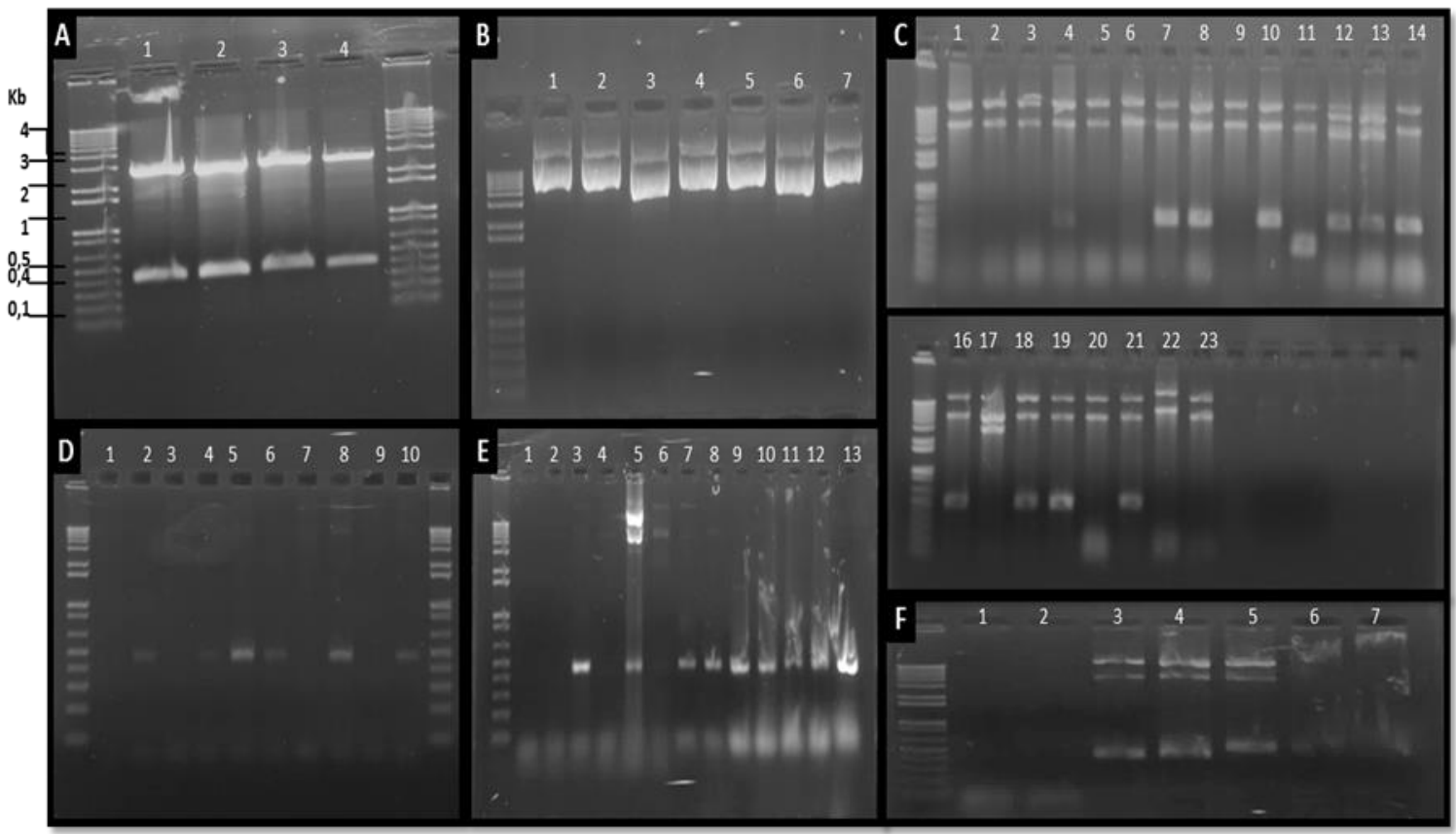

A)Digestão de pUC57 (2710 pb), contendo os insertos 2H1 VL (422 pb) e 4-4-20 VL (422 pb) digeridos com AgeI e BstAPI, 2H1 VH (435 pb) e 4-4-20 VH (429 pb) digeridos com AfeI. B)Produto de ligação, transformação e minipreparação dos construtos $2 \mathrm{H} 1 \mathrm{VH}+$ pFUSE-CHIG-mG1 (poço 1), 2H1 VH + pFUSECHIG-mG3 (poço 2), 2H1 VL+ pFUSE2-CLIg-mK (poço 3), 4-4-20 VH + pFUSE-CHIG-mG1 (poço 4), 4-4-20 $\mathrm{VH}+$ pFUSE-CHIG-mG3 (poço 5) e 4-4-20 VL+ pFUSE2-CLIg-mK (poço 6). C) Amplicons dos clones: 4-4-20 $\mathrm{VH}+$ pFUSE-CHIG-mG1 (poço 4), 2H1 VH + pFUSE-CHIG-mG3 (poço 7, 8 e 10), 2H1 VH + pFUSE-CHIGmG1 (poço 12-14, 16, 18, 19 e 21); D)4-4-20 VH + pFUSE-CHIG-mG3 (poço 2, 4-6, 8 e 10); E)4-4-20 VH + pFUSE-CHIG-mG1 (poço 3, 5, 7-13); F)2H1 VH + pFUSE2-CLIg-mK (poço 3-5), 4-4-20 VL pFUSE2-CLIg$\mathrm{mk}$ (poço 6). O marcador utilizado foi $1 \mathrm{~kb}$ plus DNA ladder (Invitrogen).

Tabela 4 - Análise da qualidade de sequências nucleotídicas dos clones 2H1 e 4-4-20.

\begin{tabular}{lcccc}
\hline Read name & Total of bp & Quality >20 bp & Quality >30 bp & >100 bp, quality >20 \\
\hline 4-4-20mG3 Forward & 1106 & $603(55 \%)$ & $548(50 \%)$ & Ok \\
4-4-20mG3 Reverse & 1064 & $583(55 \%)$ & $559(53 \%)$ & Ok \\
2H1mG1 Forward & 940 & $534(57 \%)$ & $459(49 \%)$ & Ok \\
2H1mG1 Reverse & 858 & $477(56 \%)$ & $389(45 \%)$ & Ok \\
4-4-20mG1 Forward & 1037 & $569(55 \%)$ & $498(48 \%)$ & Ok \\
4-4-20mG1 Reverse & 1029 & $588(57 \%)$ & $531(52 \%)$ & Ok \\
2H1mG3 Forward & 1027 & $651(63 \%)$ & $590(57 \%)$ & Ok \\
2H1mG3 Reverse & 1019 & $620(61 \%)$ & $543(53 \%)$ & Ok \\
2H1mK Forward & 1009 & $723(72 \%)$ & $640(63 \%)$ & Ok \\
2H1mK Reverse & 1059 & $628(59 \%)$ & $563(53 \%)$ & Ok \\
4-4-20mK Forward & 1020 & $718(70 \%)$ & $651(64 \%)$ & Ok \\
4-4-20mK Reverse & 1062 & $560(53 \%)$ & $452(43 \%)$ & Ok \\
Total & $\mathbf{1 2 2 3 0}$ & $\mathbf{7 2 5 4}(\mathbf{5 9 \%})$ & $\mathbf{6 4 2 3}(\mathbf{5 3 \%})$ & Ok:12 \\
\hline
\end{tabular}


As sequências nucleotídicas dos insertos 2H1 e 4-4-20 clonados em pFUSE-CHIG-mG1, pFUSE-CHIG-mG3 e pFUSE-CLIG-mK foram analisadas pela ferramenta online PHPH (MegaBACE ou ABI), revelando que doze sequências foram maiores do que $100 \mathrm{pb}$ e apresentaram qualidade acima de 20 após sequenciamento em $\mathrm{ABI}$ 3130xl (Applied Biosystems).

Tabela 5 - Identidade de sequência de nucleotídeos e aminoácidos dos clones 2H1 e 4-4-20.

\begin{tabular}{|c|c|c|c|c|}
\hline \multicolumn{5}{|c|}{ Alinhamento de nucleotídeos totais } \\
\hline Contig & Identidade & Gap & Score & E-value \\
\hline 2H1mG3 & $1145 / 1153(99 \%)$ & $2 / 1153(0 \%)$ & 2084 & 0 \\
\hline 4-4-20mK & $1077 / 1081(99 \%)$ & 2/1081 (0\%) & 1973 & 0 \\
\hline 4-4-20mG3 & $890 / 890(100 \%)$ & $0 / 890(0 \%)$ & 1644 & 0 \\
\hline 2H1mK & $1187 / 1189(99 \%)$ & $0 / 1189(0 \%)$ & 2185 & 0 \\
\hline 2H1mG1 & $1061 / 1075(99 \%)$ & $12 / 1075(1 \%)$ & 1897 & 0 \\
\hline 4-4-20mG1 & $960 / 964(99 \%)$ & $1 / 964(0 \%)$ & 1757 & 0 \\
\hline \multicolumn{5}{|c|}{ Alinhamento de aminoácidos da região variável dos insertos } \\
\hline Contig & Identidade & Gap & Score & E-value \\
\hline 2H1mG3 & $141 / 141(100 \%)$ & $0 \%$ & 305 & $6-{ }^{112}$ \\
\hline 4-4-20mK & $136 / 136(100 \%)$ & $0 \%$ & 295 & $3-108$ \\
\hline 4-4-20mG3 & $139 / 139(100 \%)$ & $0 \%$ & 316 & $5-116$ \\
\hline 2H1mK & $136 / 136(100 \%)$ & $0 \%$ & 295 & $3-108$ \\
\hline 2H1mG1 & $141 / 141(100 \%)$ & $0 \%$ & 305 & $6^{-112}$ \\
\hline 4-4-20mG1 & $139 / 139(100 \%)$ & $0 \%$ & 316 & $5-{ }^{116}$ \\
\hline
\end{tabular}

Alinhamento de sequências no nucleotide BLAST revelou identidade entre 99 e $100 \%$ entre as sequências dos clones 2H1 e 4-4-20(que incluíam sequências das regiões variáveis e do vetor) e as sequências originais. Além das sequências variáveis, o sequenciamento também gerou sequências do vetor, o que tornou possível confirmar que os insertos estavam clonados nos vetores corretos. Alinhamento com protein BLAST mostrou a sequências de aminoácidos idênticas a dos construtos originais: 141 aminoácidos (2H1 VH), 139 aminoácidos (4-4-20 VH), 136 aminoácidos (2H1 e 4-4-20 VL). Os bits e E-value foram estatisticamente significantes.

\subsection{AVALIAÇÃO DA PRODUTIVIDADE CELULAR DE ANTICORPOS 2H1 E 4-4-20}

A princípio, os vetores confirmados por sequenciamento foram os produtores de $2 \mathrm{H} 1$ IgG3 e 4-4-20-IgG3. Desta forma, os ensaios iniciais de diluição limitante de clones foramrealizadospor cotransfecção dos vetores recombinantes de cadeia constante leve $(2 \mathrm{H} 1$ $\mathrm{VL}+$ pFUSE-CLIG-mK ou 4-4-20 VL + pFUSE-CLIG-mK) e pesada (2H1 VH + pFUSECHIG-mG3, pFUSE-CHIG-mG3 ou 4-4-20 VH + pFUSE-CHIG-mG3) com dois reagentes de transfecção diferentes, Lipofectamina 2000 (Invitrogen) e K2 (Biontex). Ensaio preliminar de quantificação dos anticorpos direto de sobrenadante de culturarevelou que a produtividade foi maior em clones selecionados por diluição limitante e transfectados com lipofectamina (Erro! onte de referência não encontrada. 15, Figura 16). Quando o sobrenadante foi coletado de clones produtores de 2H1-IgG3 em pool, a DO(405nm) variou entre 0,15 e 0,2. Já em sobrenadante coletado de clones individualizados, a DO (405nm)obtida foi de até 0,68 (Erro! 
onte de referência não encontrada. 15, clone T1-30). A produtividade de clones produtores de 4-4-20-IgG3 em pool e indiviualizados foi semelhante a de 2H1-IgG3, apresentando DO de sobrenadante de pool entre 0,1 e 0,22 e a DO máxima de sobrenadante de clones individualizados de 0,52 (Figura 16, clone T5-4). Quantificação posterior dos clones 2H1IgG3 revelou concentração por ELISA-GXM maior entre os clones T3-4 e T3-5 transfectados com K2 (Figura 17), diferentemente do resultado obtido na análise anterior, onde os clones T1-31 e T1-30 apresentaram maior produtividade.

Figura 15 - DO por ELISA de clones produtores de 2H1-IgG3selecionados por diluição limitante.

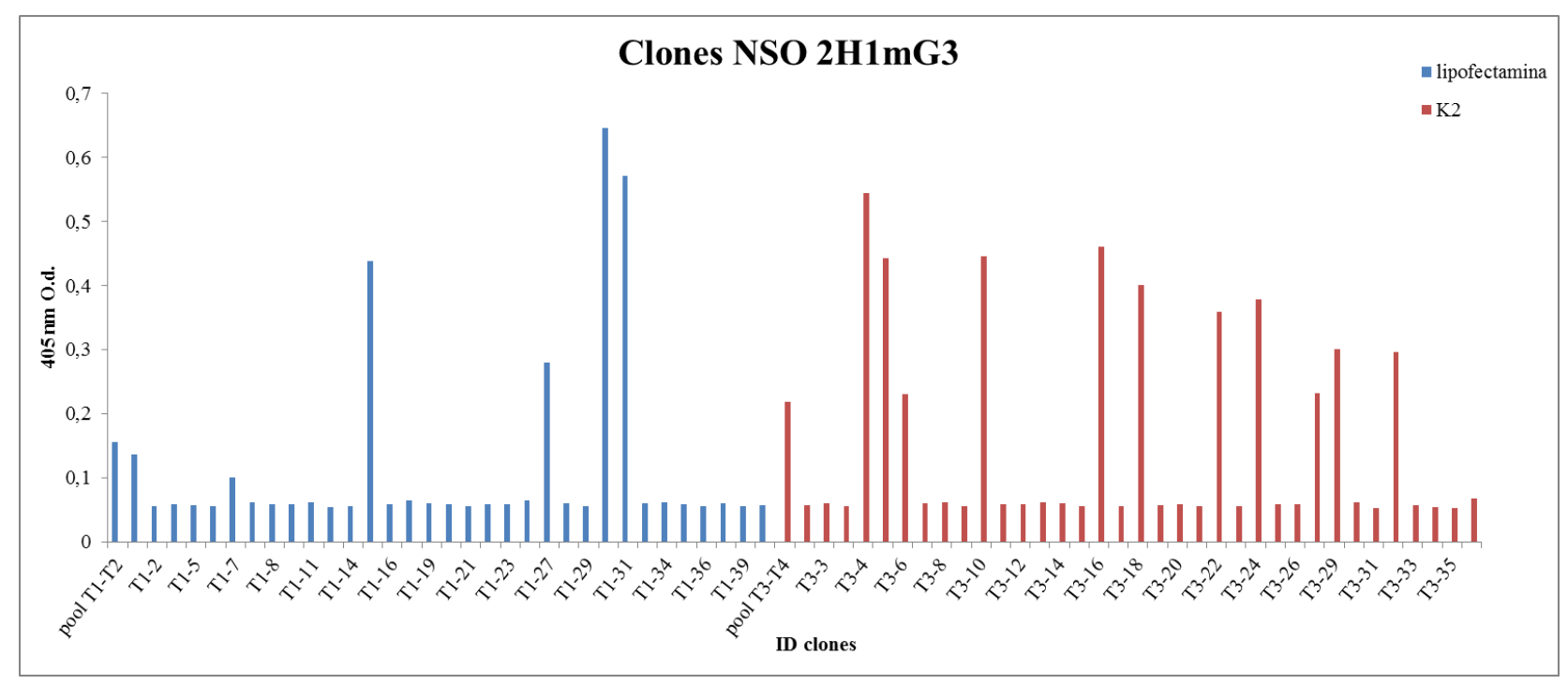

Os clones estão identificados segundo as condições de transfecção em lipofectamina (T1 e T2) e K2 (T3 e T4). Além disso, a proporção DNA: reagente de transfecção difere: T1 e T3 (1:3) e T2 e T4 (1:4).

Figura 16 - DO por ELISA de clones produtores de 4-4-20-IgG3 selecionados por diluição limitante.

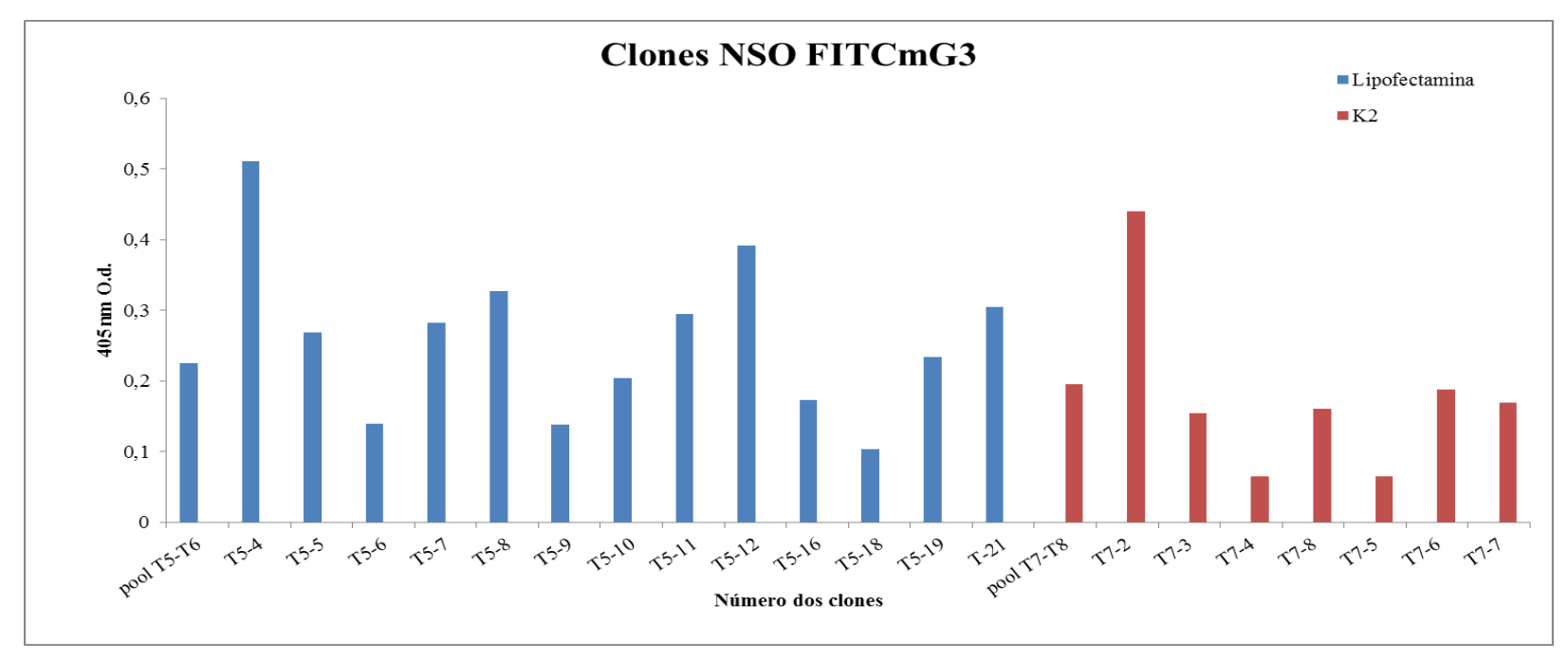


Os clones estão identificados segundo as condições de transfecção em lipofectamina (T5 e T6) e K2 (T7 e T8). Além disso, a proporção DNA: reagente de transfecção difere: T5 e T7 (1:3) e T6 e T8 (1:4).

Figura 17 - Concentração por ELISA $(\mu \mathrm{g} / \mathrm{mL})$ dos clones produtores de 2H1IgG3selecionados por diluição limitante.

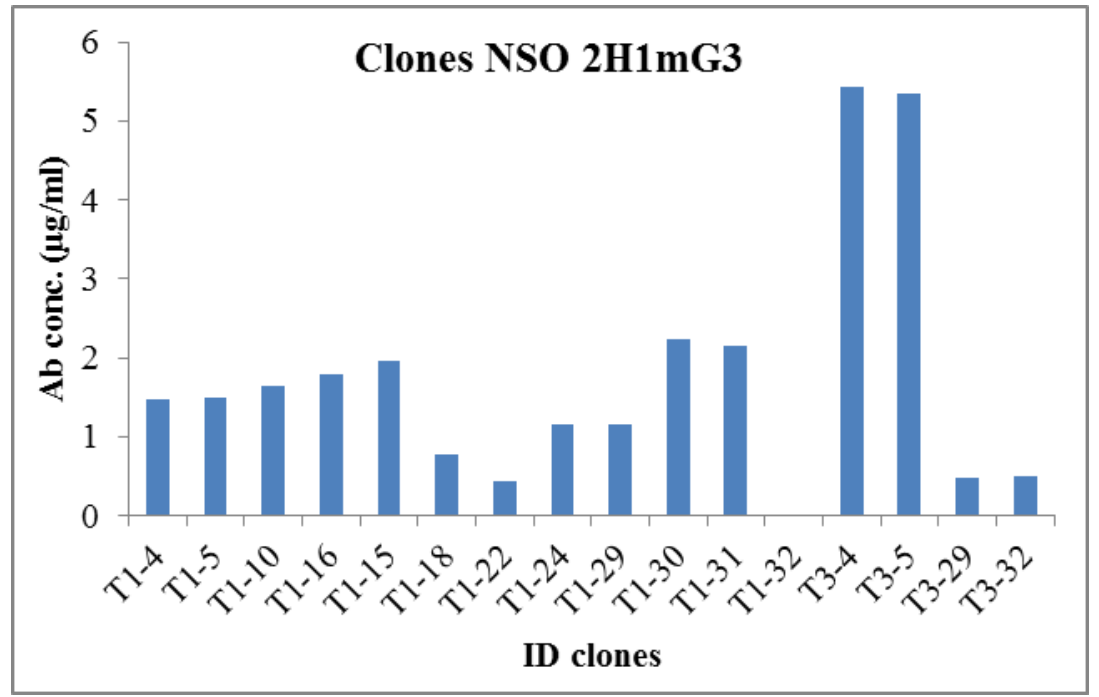

Os clones estão identificados segundo as condições de transfecção em lipofectamina (T1) e K2 (T3). A proporção de DNA: reagente de transfecção de ambos (T1 e 3) é 1:3. O R ${ }^{2}$ deste ELISA foi de 0,977.

A pureza dos anticorpos 2H1-IgG3 (clones T3-4, T3-5) e de 4-4-20-IgG3 (clones T54, T7-2) foi determinada por SDS-PAGE sob condições desnaturante e não-desnaturante. As amostras foram previamente concentradas (5x), utilizando Vivaspin de 10 a 100 MWCO (GE Healthcare Life sciences). Como observado na Figura 18, a pureza dos anticorpos foi razoável mesmo sem eles terem sido submetidos a processo de purificação. Se a concentração das amostras fosse comparada pela intensidade de bandas, 4-4-20 apresentaria concentração similar a dos anticorpos 2H1. Os anticorpos apresentaram massa molecular esperadaem condição nativa de $\pm 150 \mathrm{kDa}$, e em condição desnaturante foi evidenciada cadeia leve $( \pm 25$ $\mathrm{kDa})$ e pesada $( \pm 50 \mathrm{kDa})$. 
Figura 18 - SDS-PAGE de anticorpos 2H1-IgG3 e 4-4-20-IgG3 não purificados.

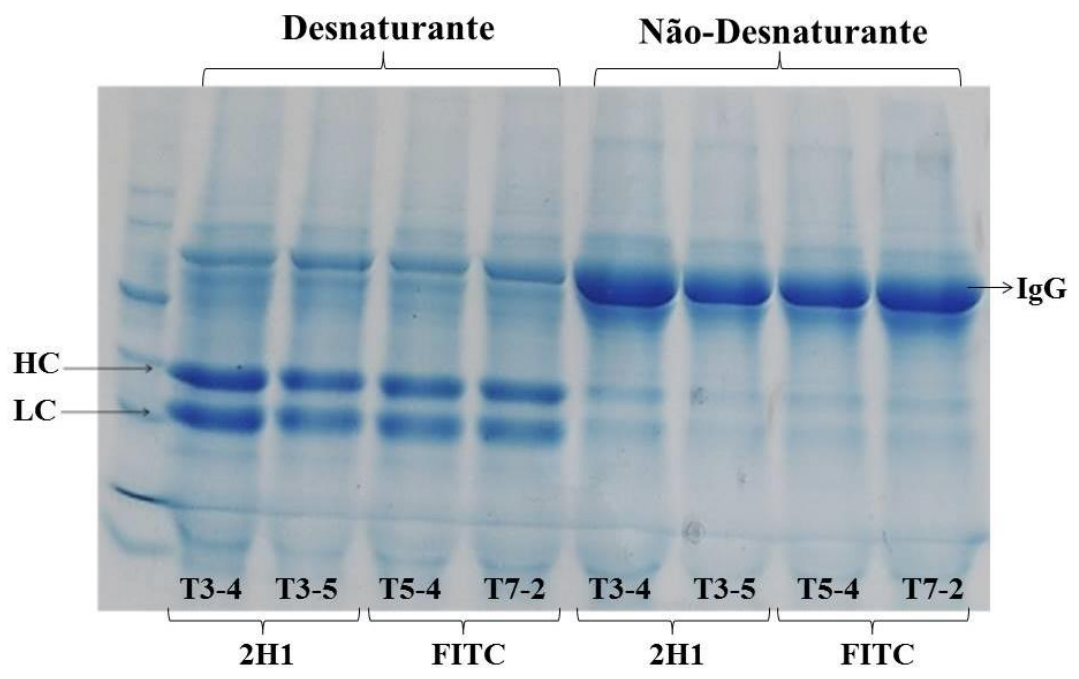

Os clones de maior produtividade foram selecionados para expansão do cultivo e avaliação dos anticorpos por SDS-PAGE. Anticorpos 2H1-IgG3 avaliados foram provenientes dos clones nas condições de transfecção T3 (proporção DNA:K2 1:3), enquanto que 4-4-20-IgG3 foram provenientes de clones T5 (DNA:lipofectamina 1:3) e T7 (DNA:K2 1:3).

Assim que foram confirmadas as sequências dos clones produtores de 2H1-IgG1 e 44-20-IgG1, os vetores recombinantes de cadeia leve (2H1 VL + pFUSE-CLIG-mK ou 4-4-20 $\mathrm{VL}+$ pFUSE-CLIG-mK) e pesada (2H1 VH + pFUSE-CHIG-mG1 ou 4-4-20 VH + pFUSECHIG-mG1) foram cotransfectados em células NSO e CHO para produção dos anticorpos. Após cultivo, foi realizada coleta em pool dos clones 2H1-IgG1 transfectados na condição DNA: lipofectamina, proporção 1:3 (T1) e DNA:K2, proporção 1:3 (T2); assim como pool dos clones 4-4-20-IgG1 transfectados nas mesmas condições (porém denominados T3 e T4). Para avaliar a produtividade de anticorpos 2H1-IgG3 e 4-4-20-IgG3 por NSO e CHO.Foi também realizada transfecção nas mesmas condições anteriores para produção de 2H1-IgG3 e 4-4-20-IgG3; além do cultivo e coleta do sobrenadante em pool para análise. A produtividade das células $\mathrm{CHO}$ não foi testada anteriormente, visto que apenas a partir deste momento as células se tornaram disponíveis. Dados de DO $(405 \mathrm{~nm})$ mensurados por ELISA, foram obtidos a partir dos sobrenadantes de cultura provenientes das condições mencionadas, e também após seleção por antibióticos Blasticidina e Zeocina (Invitrogen).O resultado de DO foi variável dependendo do tipo celular e do reagente de transfecção (Figura 19 e Figura 20). Embora a produtividade por célula NSO não tenha sido comprovadamente maior do que a de $\mathrm{CHO}$, não foi possível adaptar células $\mathrm{CHO}$ a crescimento livre de SFBe,portanto, a célula NSO foi eleita para produção dos anticorpos. Dessa forma, o cultivo de célula CHO foi descontinuado até a seleção de clones. 
Figura 19 - Produtividade anticorpos 2H1-IgG1/IgG3 por células CHO e NSO mensurada por ELISA.

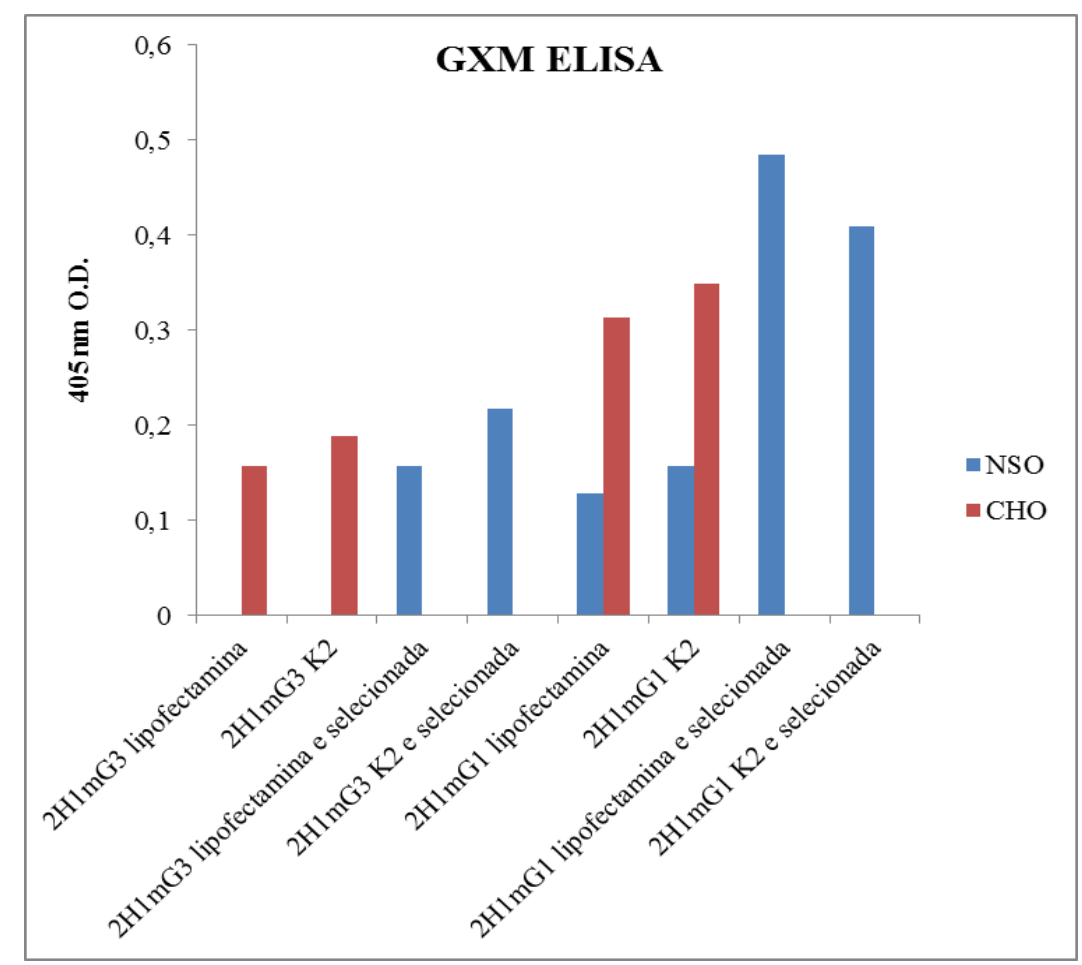

A maior produtividade de 2H1-IgG1 foi obtida por células NSO transfectadas com lipofectamina e selecionadas. Enquanto que 2H1-IgG3 apresentou maior produtividade em células NSO transfectadas com K2 e selecionadas.

Figura 20 - Produtividade anticorpos 4-4-20-IgG1/IgG3 por células CHO e NSO mensurada por ELISA.

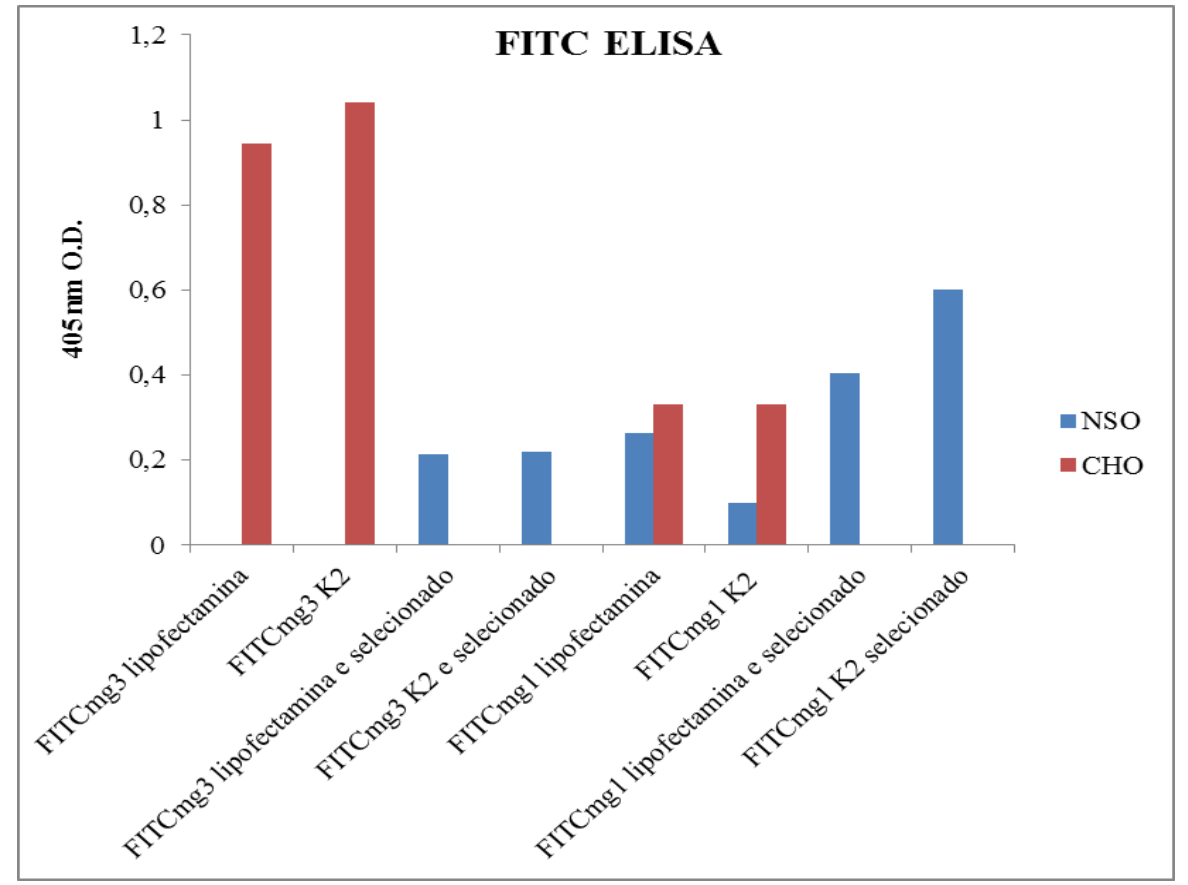

A maior produtividade de 4-4-20-IgG1 foi obtida por células NSO transfectadas com K2 e selecionadas. Enquanto que 4-4-20-IgG3 apresentou maior produtividade em células $\mathrm{CHO}$ transfectadas com K2 e não selecionadas. 
Os clones produtores dos quatro tipos de anticorpos 2H1-IgG1 (T1 e T2), 2H1-IgG3 (T3-4, T3-5), 4-4-20-IgG1 (T3 e T4) e 4-4-20-IgG3 (T5-4, T7-2) que apresentaram maior produtividade foram adaptados a crescimento em meio livre de SFB e cultivados em placas de 6 poços para serem utilizados nos experimentos seguintes.

Ensaio piloto de ELISA foi realizado para quantificação dos quatro anticorpos diretamente do sobrenadante das culturas em meio sem SFB. Eles se apresentaram específicos contra os respectivos antígenos GXM e FITC, na concentração de $3 \mu \mathrm{g} / \mathrm{mL}$ (2H1-IgG1), 1,5 $\mu \mathrm{g} / \mathrm{mL}$ (2H1-IgG3), 0,47 $\mu \mathrm{g} / \mathrm{mL}$ 4-4-20-IgG1 e 0,42 $\mu \mathrm{g} / \mathrm{mL}$ (4-4-20-IgG3) (Figura 21). A quantificação de anticorpos 4-4-20 por placa coberta com BSAconjugada a FITC foi testada, mas como não há anticorpo padrão anti-4-4-20, não foi possível obter quantificação precisa (Figura 21)

Figura 21 - Quantificação de anticorpos 2H1-IgG1/IgG3 e 4-4-20-IgG1/IgG3 por ELISA.
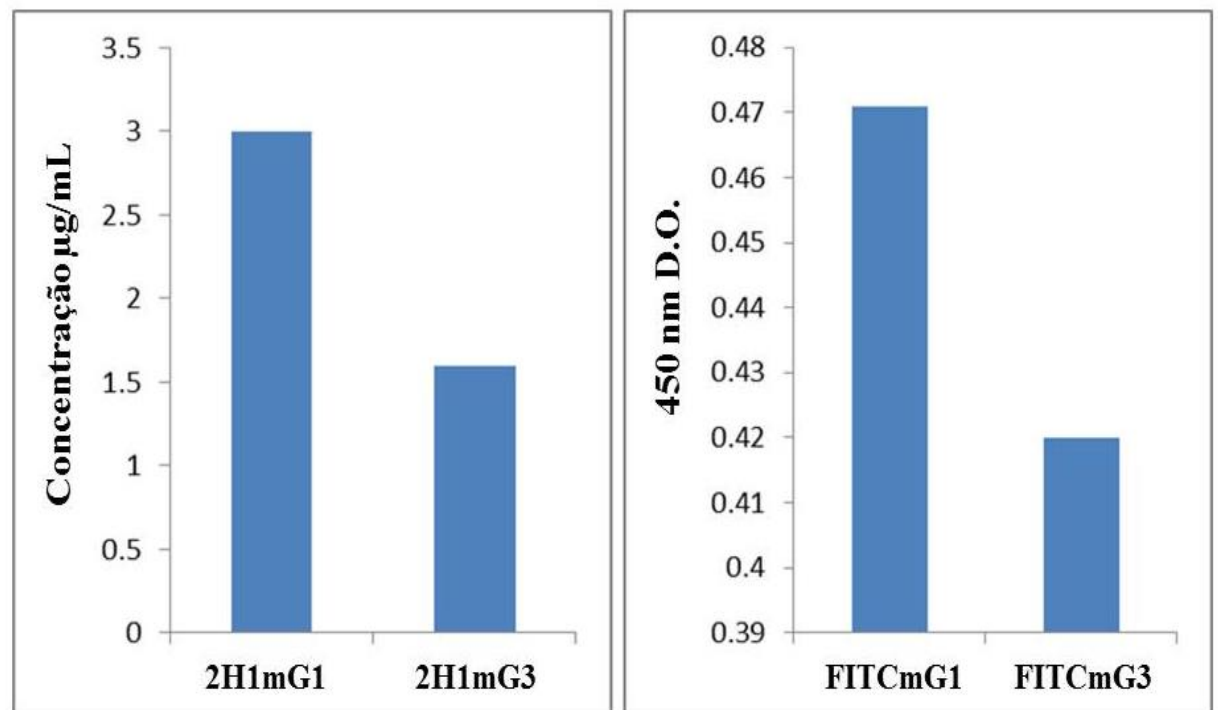

Anticorpos IgG1 apresentaram valores maiores de DO do que anticorpos IgG3. Os anticorpos foram proveniente dos clones obtidos por diluição limitante 2H1-IgG3 (T3-4, T3-5), 4-4-20-IgG3 (T5-4, T7-2); e de sobrenadante colhido em pool dos clones 4-4-20-IgG1 (T3 e T4) e 2H1-IgG1 (T1 e T2).

\subsection{PRODUÇÃO E ENSAIO PILOTO DE ANTICORPOS}

O primeiro lote de produção de anticorpos foi realizado a partir de sobrenadante de células NSO não adaptadas a cultivo sem SFB, não purificado, colhido antes da seleção com antibiótico(as células foram cultivadas por três dias) e da seleção de clone por diluição limitante. O sobrenadante colhido em pool( $1 \mathrm{~mL}$ cada anticorpo) foi proveniente do cultivo dos clones produtores dos anticorpos 2H1-IgG3 e 4-4-20-IgG3. Os testes realizados foram: fagocitose com macrófagos J774 e IFI. 
Os anticorpos 2H1-IgG3 foram produzidos por quatro pools de células transfectadas, mostrando-se capazes de se ligarem ao antígeno nativo de C. neoformans. Os anticorpos 2H1IgG3 foram capazes de induzir fagocitose de células fúngicas in vitro, em contraste a anticorpos 4-4-20-IgG3, que não induziram fagocitose. No entanto, apenas foi possível realizar o ensaio utilizando $1 \mu \mathrm{g} / \mathrm{mL}$ de $2 \mathrm{H} 1$, e em uma concentração ainda menor dos anticorpos 4-420, baseando-se na quantificação por ELISA. Dessa forma, anticorpos 2H1da condição de transfecção T1 e T2 mediaram fagocitose na porcentagem de 5\% e 15\%, respectivamente. Já nas incubações com anticorpos 2H1 em outras condições de transfecção (T3 e T4) e com 4-420, a porcentagem de fagocitose foi próxima de zero. Esse valor foi semelhante à incubação sem anticorpo (controle negativo). O controle positivo 18B7-IgG1 apresentou fagocitose aproximada de $25 \%$ na concentração $1 \mu \mathrm{g} / \mathrm{mL}$ e de $28 \%$ quando utilizado a $10 \mu \mathrm{g} / \mathrm{mL}$ (Figura 22).Os sobrenadantes utilizados eram provenientes dos clones que apresentavam as condições de transfecção na proporção DNA:reagente T1/T5 (lipofetamina 1:3), T2/T6 (lipofetamina 1:4), T3/T7 (K2 1:3), T4/T8 (K2 1:4).

Figura 22 - Porcentageme microscopia de fagocitose de $C$. neoformansopsonizados com2H1IgG3 e4-4-20-IgG3 por células J774.

\section{A)}

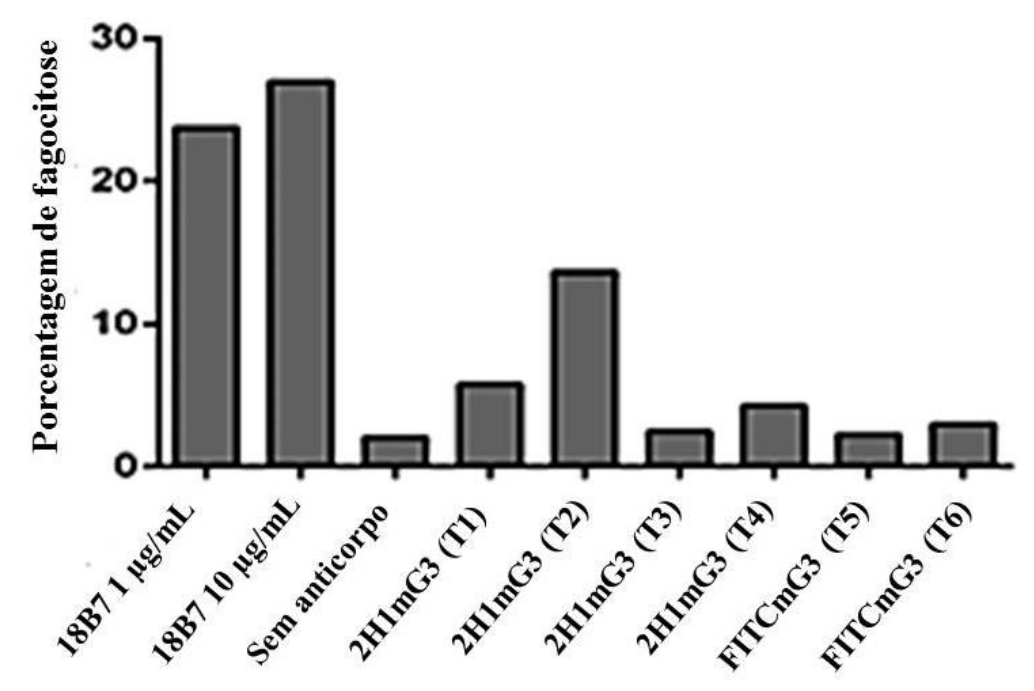


B)
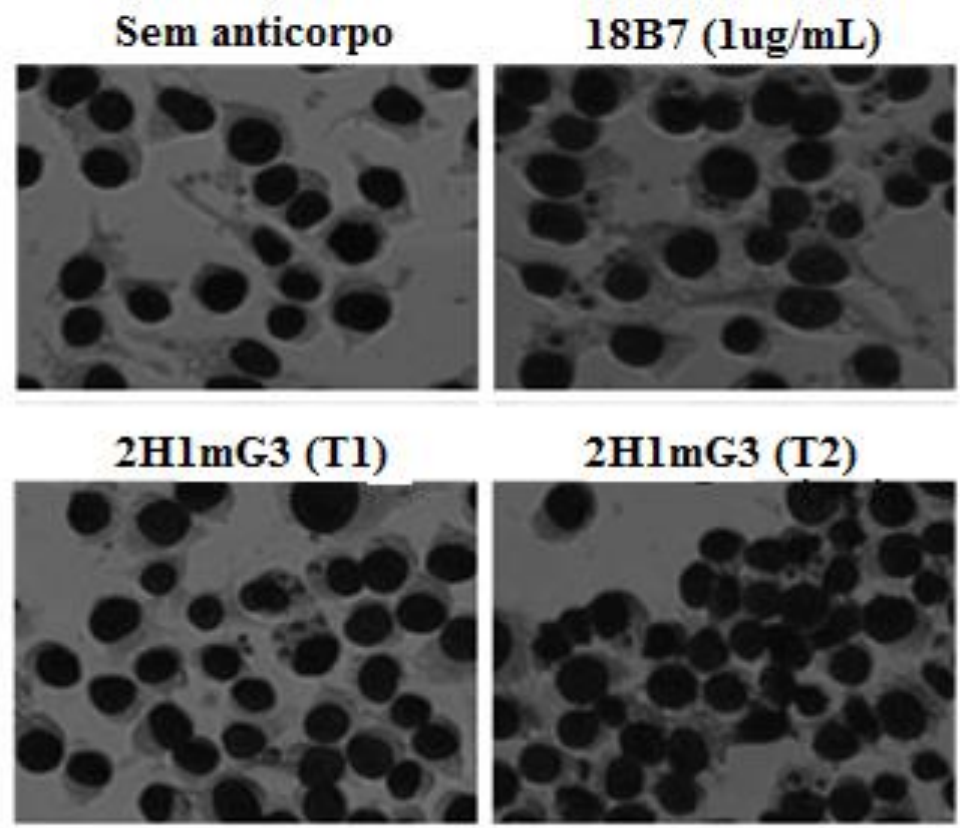

FITCmG3 (T5)

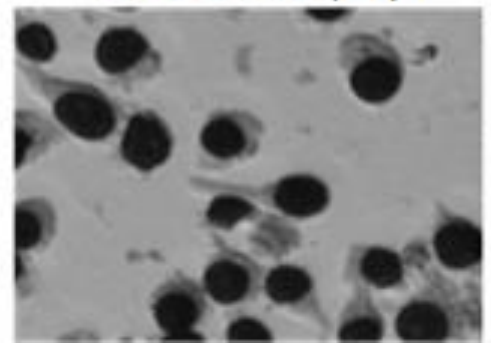

FITCmG3 (T6)

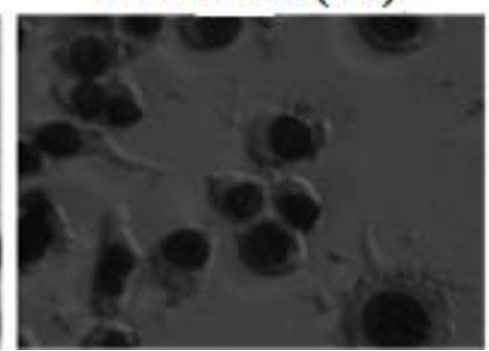

A) A porcentagem de fagocitose representa aquantificação das imagens microscópicas. O cálculo foi realizado contando 100 células J774 de, no mínimo,três campos diferentes em três ensaios experimentais para cada condição. O número de células com $C$. neoformans $\mathrm{H} 99$ internalizados foi dividido pelo número total de macrófagos (100) para obter a porcentagem.B)Imagens de microscopia representativas do cálculo de fagocitose de ensaio com anticorpos $2 \mathrm{H} 1,4-4-20$ e controles.

Para avaliar se 2H1-IgG3 ligava-seà cápsula de $C$. neoformans e qual padrão de ligação apresentava, foi realizado ensaio de imunofluorescência com anticorpos direto do sobrenadante dos clones NSO. As imagens obtidas por Contraste de Interferência Diferencial (DIC) evidenciam que a célula fúngica apresenta-se estruturalmente íntegra, enquanto que a mesma célula observada por Microscopia de Fluorescência (MF) apresentou padrão compatível com a literatura. $\mathrm{O}$ anticorpo 2H1 ligou-seà GXM de C. neoformans H99 e apresentou padrão de fluorescência puntiforme, conforme o esperado. O controle positivo 18B7-IgG1 apresentou padrão de fluorescência anular, conforme a literatura. O anticorpo 4-420 (controle negativo) não apresentou fluorescência, o que reforça que o resultado obtido com 2H1 foi verdadeiramente positivo. Reconstrução tridimensional feita por projeção-Z com os softwaresImageJ e VOXXa partir das imagens de fluorescência captadas em diferentes planos evidenciou a diferença entre os padrões de fluorescência observados para 18B7 e 2H1- 
IgG3.Os anticorpos 2H1 foram testados nas condições de transfecção T1 a T4 e os anticorpos 4-4-20 de T5 a T8. O ensaio foi realizado em triplicata em cada uma das condições experimentais(Figura 23).

Figura 23 - Ensaio de ligação dos anticorpos2H1-IgG3 e 4-4-20-IgG3à cápsula de $C$. neoformans por IFI.
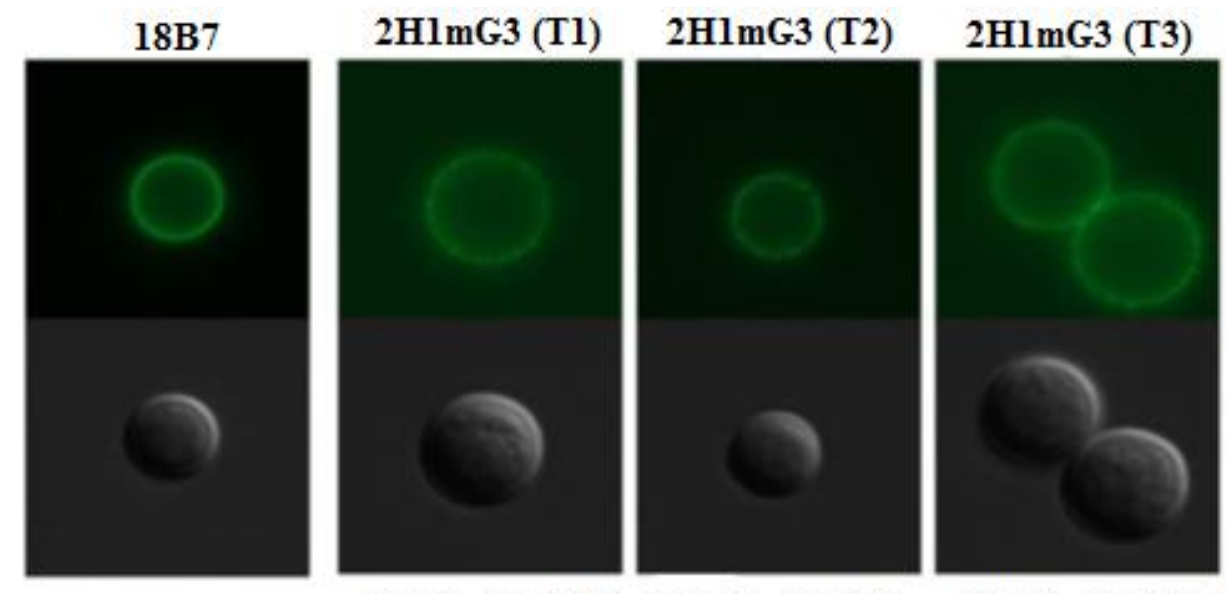

2HlmG3 (T4)
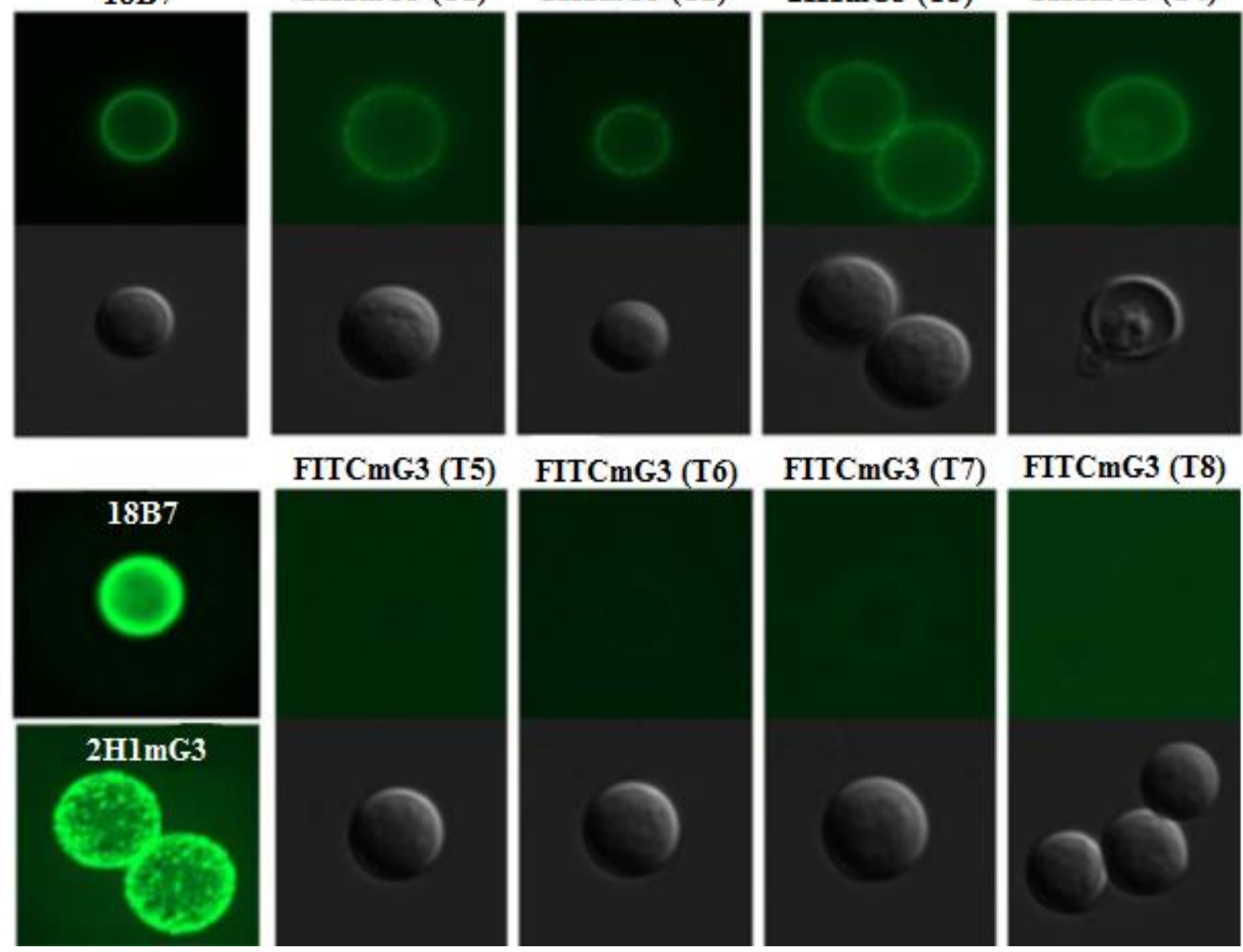

FITCmG3 (T8)

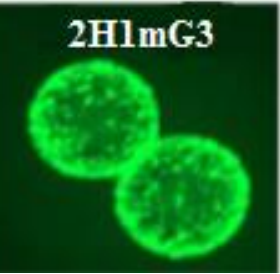

Imagens de microscopia de epifluorescência obtidas pelo Zeiss Axio Observer Z1 nas objetivas de 63X (NA 1,4). O padrão de ligação dos anticorpos à cápsula de $C$. neoformans $\mathrm{H} 99$ foi avaliado. As imagens foram obtidas em campo claro por DIC e porMF. O teste foi realizado para avaliar o padrão de ligação dos anticorpos recombinantes $2 \mathrm{H} 1$-IgG3, e o mesmo foi validado pelo controle positivo de padrão de ligação anular (18B7) e controle negativo de ligação à GXM (4-4-20-IgG3). Também foi realizada reconstrução tridimensional por projeção-Z com os softwaresImageJ e VOXX 2 para evidenciar melhor a diferença entre o padrão de ligação de 18B7-IgG1 e 2H1-IgG3. As condições de transfecção dos clones T1 a T8 foram descritas anteriormente.A concentração utilizada de cada anticorpo variou de 1 a $10 \mu \mathrm{g} / \mathrm{mL}$, já que os anticorpos usados neste primeiro teste não foram quantificados. O anticorpo secundário utilizado foi anti-IgG murina conjugada a Alexa Fluor ${ }^{\circledR}$ 488(ThermoFisher Scientific).

\subsection{PRODUÇÃO E TESTES DOPRIMEIRO LOTE DE ANTICORPOS}

Tendo produzido anticorpos em escala piloto e demonstrado que esses anticorpos se ligam à cápsula e induzem fagocitose, partimos para produção em uma escala maior. $\mathrm{O}$ primeiro lote se refere à produção escalonada de anticorpos2H1-IgG1 e 2H1-IgG3, 
purificação por troca aniônica, precipitação com SAS, ultrafiltração, ELISA,SDS-PAGEe ensaio de fagocitose com células $\mathbf{J} 774$.

A cultura dos clones que apresentaram melhores produtividades de anticorpos foi escalonada para frascos de $175 \mathrm{~cm}^{2}$ em meio sem soro e depois de cinco dias tiveram os sobrenadantes colhidos para serem, então, purificados e concentrados. O escalonamento foi feito para aumentar a concentração de anticorpos recuperados. Diferentes métodos cromatográficaos foram utilizados, e mesmo o método clássico de purificação com HiTrap Protein Gnão obteve sucesso (visto que não foi possível eluir os anticorpos da coluna). A tentativa seguinte foi a de eliminar os contaminentes de cultura celular grosseiramente por ultrafiltração, o que também não foi possível porque algum componente do meio $C D$ Hybridoma tornou a ultrafiltração excessivamente lenta. Dessa forma, optou-se pelo modo de purificação não ligante, realizado com método de troca aniônicaHiScreen Capto DEAE(Figura 24). O método foi seguido de precipitação com SASpara facilitar a concentração das proteínas, uma vez que também era lenta e baixa a recuperação por ultrafiltração utilizando volume alto de sobrenadante de cultura $(150 \mathrm{~mL}$ a $300 \mathrm{~mL})$.

Figura 24 - Cromatografia DEAE de 2H1-IgG3 em modo não ligante.

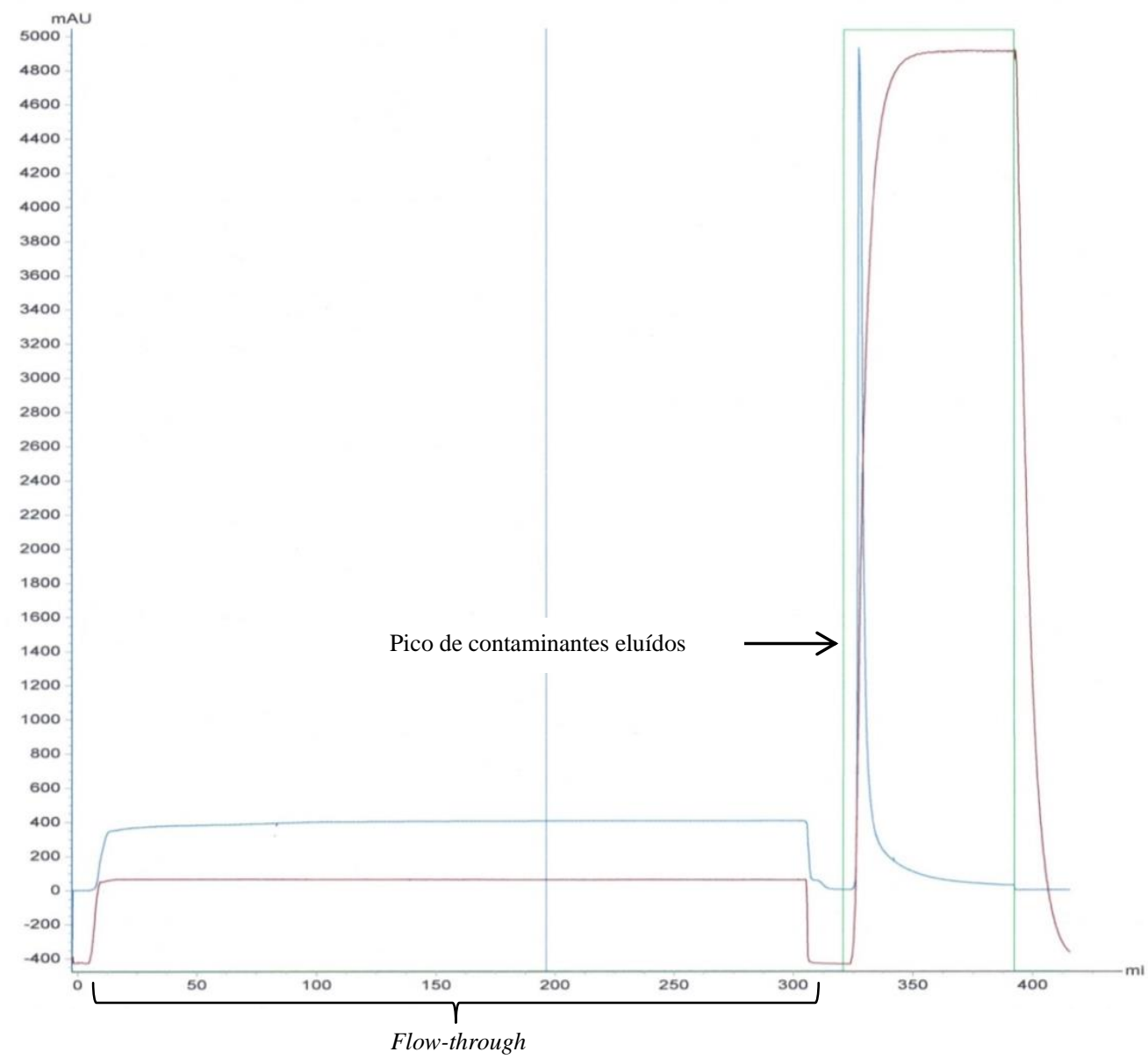


Cromatograma de troca aniônica em coluna Q (trocador aniônico forte) HiScreen Capto DEAE(GE, Life sciences),obtido no cromatógrafoAkta Avant 25, de 2H1-IgG3 evidenciou que a amostra é liberada no flowthrough no modo não ligante, e que os contaminantes do sobrenadante de cultura celular apresentaram volume de retenção na coluna próximo a $320 \mathrm{~mL}$. A eluição dos contaminantes ocorreu quando houve aumento de concentração de sal.

Para avaliar o processamento dos sobrenadantes, alíquotas após cada método foram colhidas e tiveram sua concentração testada por ELISA (Figura 25). Os anticorpos 2H1IgG1apresentaram quantificação total $(\mu \mathrm{g})$ de 124,8 (sobrenadante), 122,1 (DEAE flowthrough), 75,48 (precipitação por SAS), 104,62 (ultrafiltração). Os anticorpos 2H1-IgG3 apresentaram quantificação total de 42 (sobrenadante), 40,3 (DEAE flowthrough), 38,3 (precipitação), 46,2 (ultrafiltração). A perda de anticorpos foi relativamente baixa durante o processo e a quantificação reduzida após a precipitação foi provavelmente devido interferência de sal no ELISA.

Figura 25 - Quantificação de anticorpos $2 \mathrm{H} 1$ ao longo dos processos de purificação e concentração.

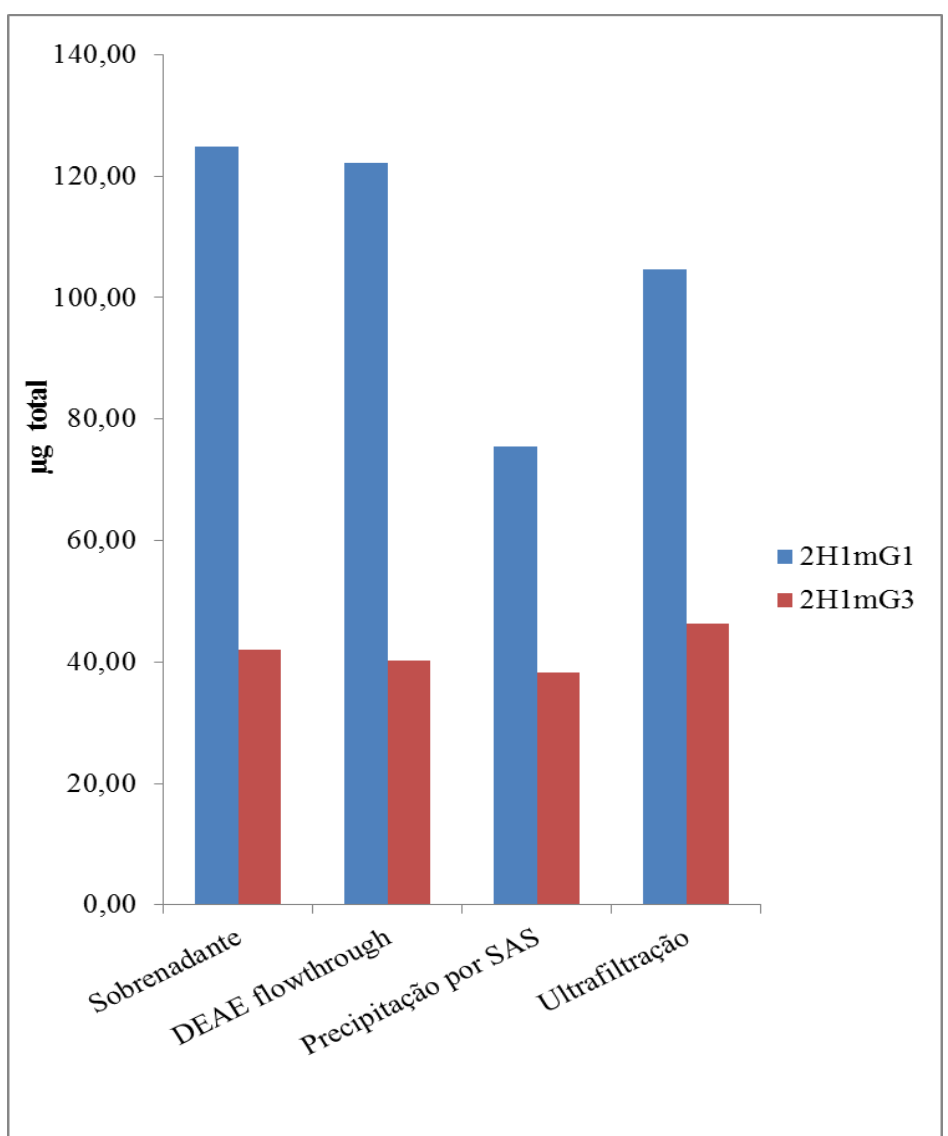

Os anticorpos 2H1-IgG1 e 2H1-IgG3 foram quantificados por ELISA após a produção em cultura NSO, purificação por DEAE, precipitação por SAS e ultrafiltração. Eles apresentaram concentração baixa inicialmente, provavelmente porque as amostras estavam mais diluídas a princípio. $\mathrm{O}$ resultado final mostrou que a concentração de $2 \mathrm{H} 1-\mathrm{IgG} 1$ foi de $75 \mu \mathrm{g} / \mathrm{mL}$ e de $2 \mathrm{H} 1-\mathrm{IgG} 3$ de $31 \mu \mathrm{g} / \mathrm{mL}$. O R ${ }^{2}$ deste ELISA foi de $0,946$. 
O SDS-PAGE foi realizado, contudo as amostras não foram claramente evidenciadas. Foi observado nos poços que as amostras migraram de forma não uniforme, o que pode ter acontecido devido à quantidade de sal residual do processo de precipitação. Isso ocorreu mesmo após as amostras serem dialisadas e concentradas por ultrafiltração. O controle positivo $18 \mathrm{~B} 7(\mathrm{IgG} 1)$ foi utilizado a $1 \mu \mathrm{g}, 0,5 \mu \mathrm{g}$ e $0,25 \mu \mathrm{g}$. Após serem submetidas à condição desnaturante, as cadeias leve ( $\sim 25 \mathrm{kDa})$ e pesada ( $\sim 50 \mathrm{kDa})$ foram evidenciadas(Figura 26$)$.

Figura 26 - SDS-PAGE de anticorpos 2H1-IgG1/IgG3

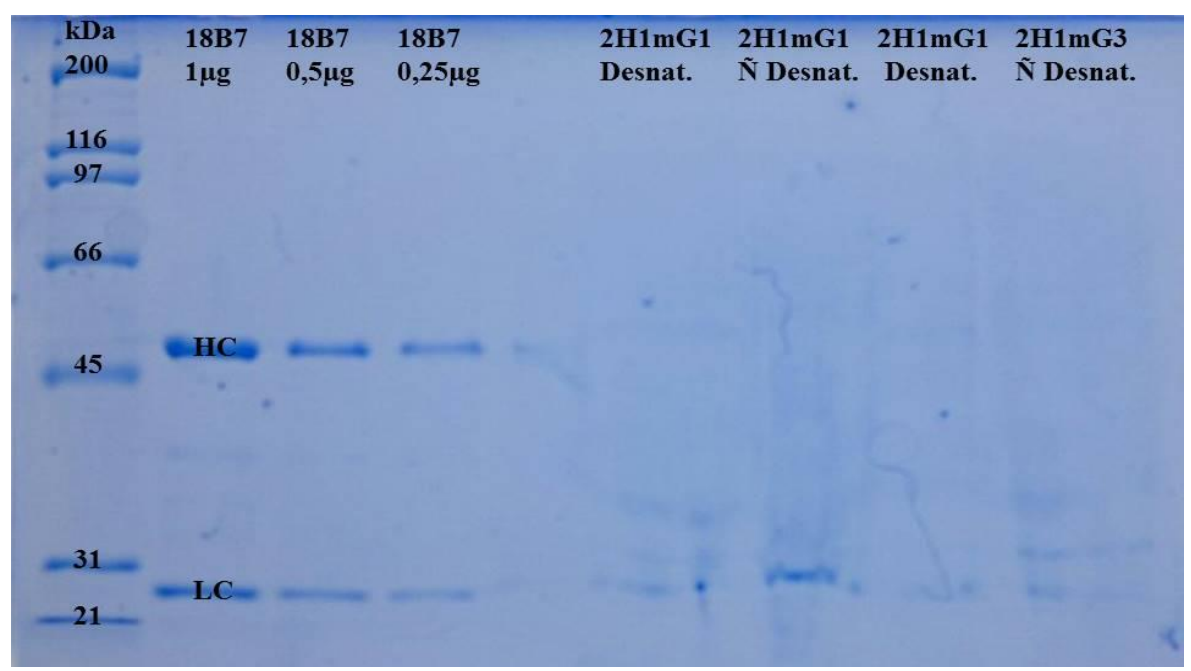

Foram adicionados 16 microlitros do concentrado final dos anticorpos recombinantes 2H1-IgG1 e IgG3 (poços 6-9) para diluição do tampão de amostra desnaturante/não desnaturante 5x. No entanto, devido ao excesso de sal, as amostras migraram de forma irregular. Também foram utilizados controles positivos a $1,0,5$ e $0,25 \mu \mathrm{g}$ que evidenciaram cadeia pesada e leve em condição desnaturante. O marcador utilizado foi o Broad Range.

Os anticorpos 2H1-IgG1 e 2H1-IgG3 mediaram fagocitose de C. neoformans por macrófagos $\mathbf{J} 774$, após duas horas de incubação com o fungo na proporção efetor:alvo 1:2, com alta eficiência e de forma estatisticamente significativa. Os anticorpos 2H1-IgG1 mediaram fagocitose de $84 \%$ e $2 \mathrm{H} 1-\mathrm{IgG} 3$ de $82 \%$. Os controles positivo (18B7) e negativo (nenhum anticorpo) apresentaram porcentagem de fagocitose $80 \%$ e próxima a $0 \%$, respectivamente (Figura 27 A e B). O mesmo teste foi feito usando células $\mathrm{CHO}$, mas não houve fagocitose em nenhum dos poços (Figura $27 \mathrm{C}$ ). A concentração final de cada anticorpo usada nos experimentos de fagocitose foi de $10 \mu \mathrm{g} / \mathrm{mL}$.

Figura 27 - Ensaio de fagocitose de C. neoformans opsonizado com 2H1-IgG1 e 2H1-IgG3 
A)

B)
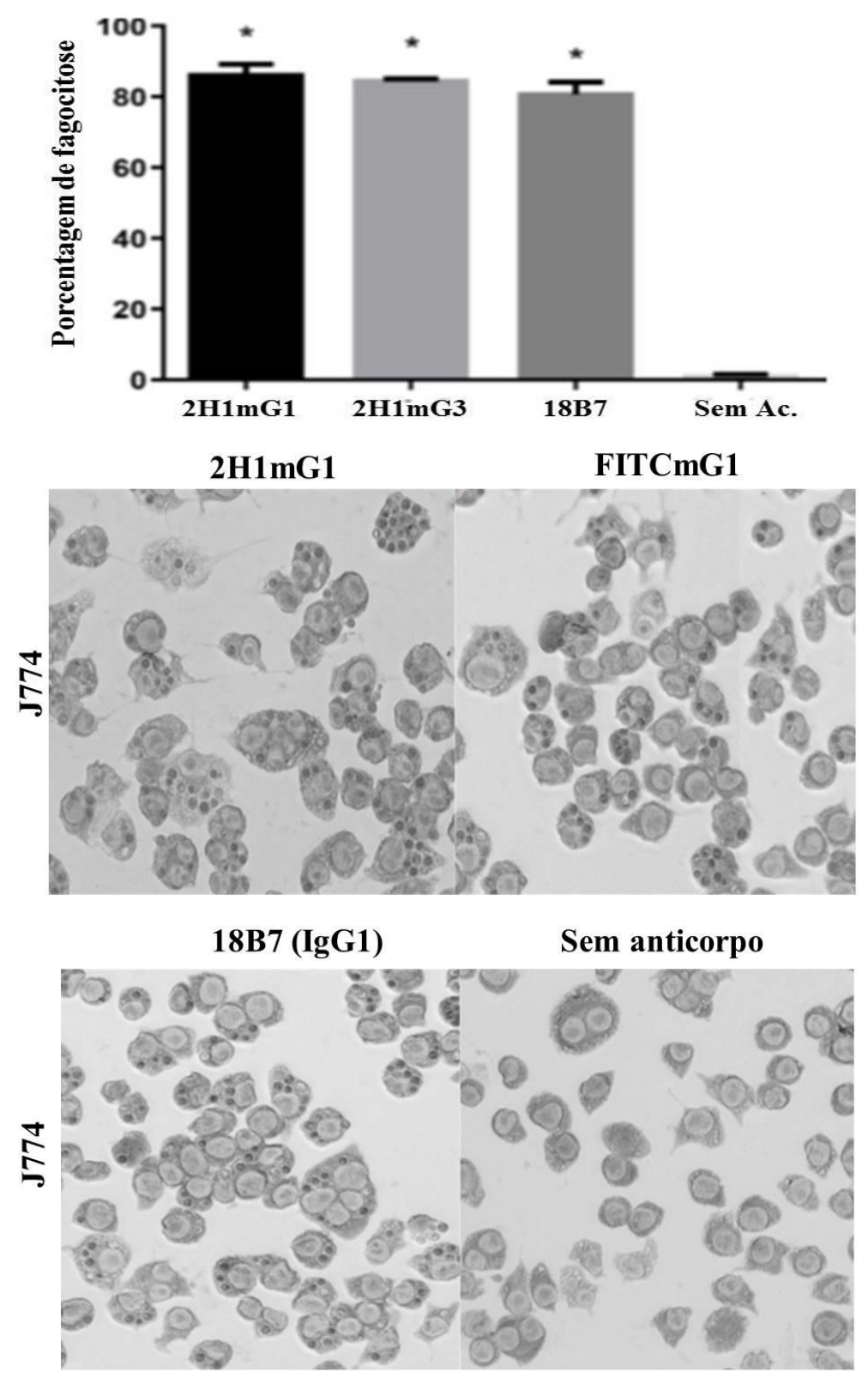

C)

Sem anticorpo

2H1mG1

2H1mG3

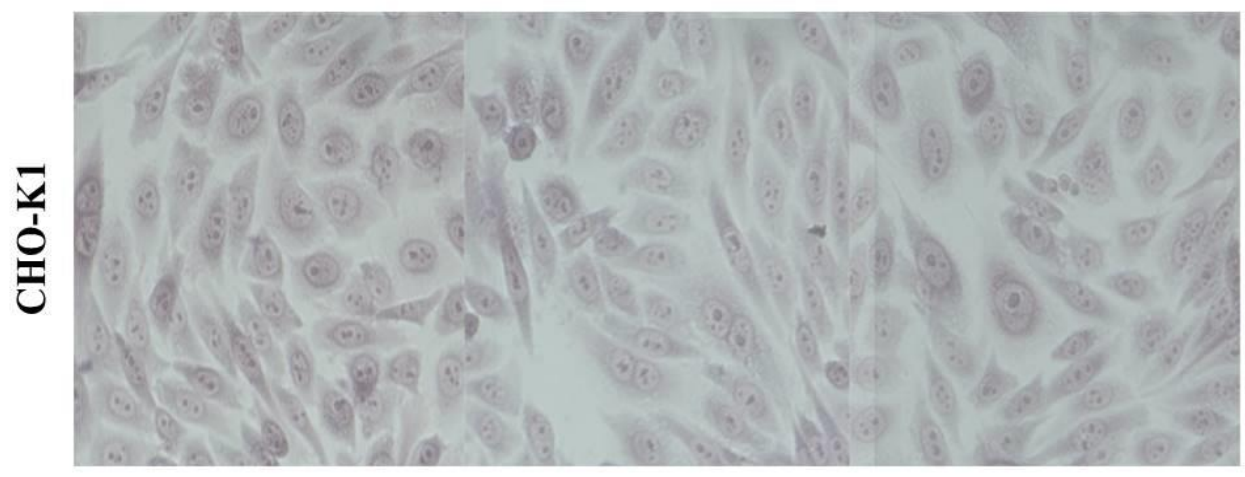

A) A porcentagem de fagocitose representa aquantificação das imagens microscópicas. O cálculo foi realizado contando 100 células $\mathbf{J} 774$ de, no mínimo,3 campos diferentes em três ensaios experimentais para cada condição. O número de células com $C$. neoformans $\mathrm{H} 99$ internalizados foi dividido pelo número total de macrófagos (100) para obter a porcentagem. O símbolo * representa que as comparações entre a porcentagem de fagocitose dos 
anticorpos recombinantes, controle positivo e controle sem anticorpo foram estatisticamente significantes(P $<0,05)$. (B) Imagens de microscopia representativas do cálculo de fagocitose de ensaio com anticorpos $2 \mathrm{H} 1 \mathrm{e}$ controles. C) Imagens de microscopia representa de fagocitose por células CHO-K1 do fungo mediada pelos anticorpos $2 \mathrm{H} 1$, semelhante ao controle negativo (sem anticorpo). Os anticorpos primários foram testados na concentração de $10 \mu \mathrm{g} / \mathrm{mL}$.

\subsection{PRODUÇÃO E TESTES DOSEGUNDO LOTE DE ANTICORPOS}

Nesse segundo lote, os anticorpos 2H1-IgG1, 2H1-IgG3, 4-4-20-IgG1 e 4-4-20-IgG3 foram produzidos no mesmo escalonamento anterior, purificados por DEAE, precipitados duas vezes por SAS, concentrados por ultrafiltração antes e depois de purificação por gel filtração. Os testes realizados com anticorpos desse lote foram: ELISA, SDS-PAGE, nanofotometria, fagocitose por J774 e CHO-K1, e IFI.

Para remoção do sal da amostra, inicialmente foi realizada cromatografia de exclusão molecularde 18B7 para determinar o volume de retenção do anticorpo na coluna, que foi de 47,7 mL. A amplitude do pico foi de 9,37 mL, calculada por leitura em UV280 . Desta forma, gel filtração de 2H1-IgG1 evidenciou o mesmo padrão de retenção e amplitude de 18B7. A Figura 28 evidencia pico de condutividade logo após o pico de eluição do anticorpo, que representa a área de retenção do sal.

Figura 28 - Cromatrografia de exclusão molecular de 2H1-IgG1.

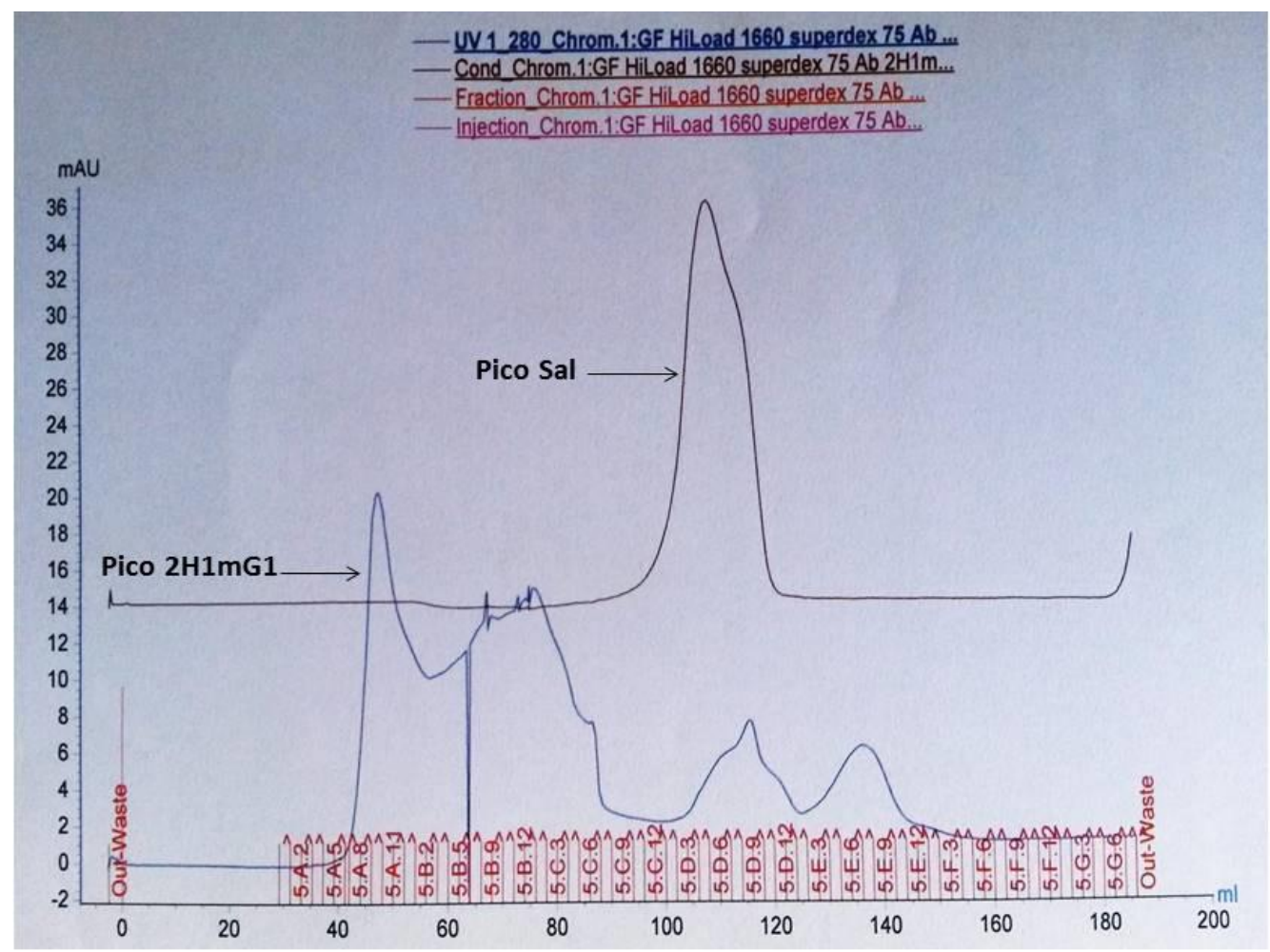


O cromatograma de 2H1-IgG1 realizado por cromatografia de exclusão molecular HiLoad 16/600 Superdex 75 pg em Akta Avant 25 evidencia eluição da amostra no volume de retenção da coluna em $47 \mathrm{~mL}$ a partir de deteç̧ão por UV $280 \mathrm{~nm}$. Eluição de contaminação por sal ocorre quando há aumento de condutividade.

$\mathrm{O}$ teste de ELISA foi realizado para quantificar as amostras de anticorpos $2 \mathrm{H} 1$ durante o processo de purificação, precipitação, concentração e filtração (Figura 29). Foi observado que o anticorpo 2H1-IgG1 obteve quantidade do produto final de $134 \mu \mathrm{g}$. Contudo, ao avaliar as quantidades obtidas em procedimentos prévios apósprecipitação $(297 \mu \mathrm{g})$, concentração do precipitado $(271 \mu \mathrm{g})$, injeção para gel filtração $(276 \mu \mathrm{g})$ e mesmo do pico de purificação (254 $\mu \mathrm{g}$ ), percebe-se que boa parte do anticorpo foi perdida no processo de concentração final (146 $\mu \mathrm{g})$ e filtração após concentração final $(134 \mu \mathrm{g})$. Uma segunda precipitação com SAS foi realizada de um volume residual de 2H1-IgG1na tentativa de recuperar o anticorpos que não precipitaram na primeira tentativa. Apenas foi quantificado o produto final de $2 \mathrm{H} 1-\mathrm{IgG} 3$, que apresentou $64 \mu \mathrm{g}$, sem avaliar o processo. Os anticorpos 4-4-20 também foram produzidos pelo mesmo procedimento, no entanto não foi possível quantificá-los por falta de padrão adequado para ELISA.

Figura 29 - Quantificação de anticorpo 2H1-IgG1 durante processos de purificação, precipitação, concentração e filtração; e quantificação final de 2H1-IgG3.

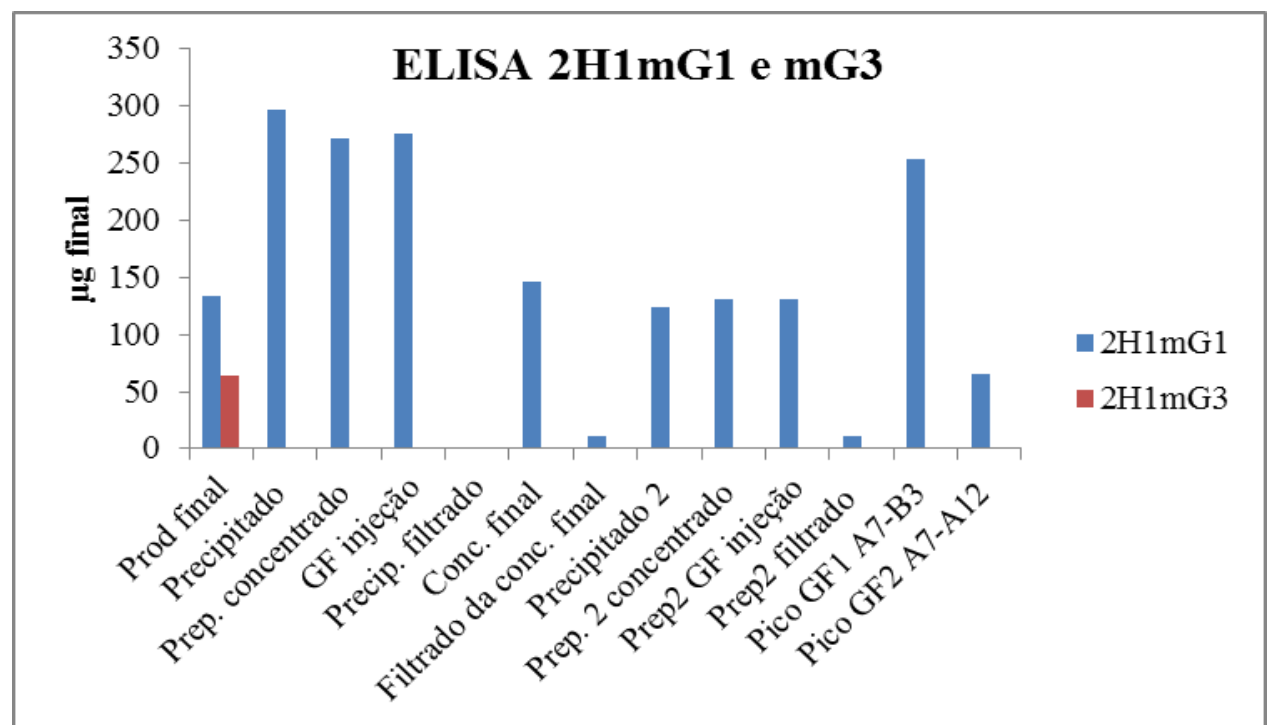

Quantificação de anticorpos recombinantes 2H1 por ELISA durante o processo de purificação, precipitação e concentração, evidencia perda de anticorpos durante a ultrafiltração em tubos Vivaspin (GE Healthcare Life sciences) e Amicon (Millipore) 10kDa. A quantidade final de 2H1-IgG1 foi de $134 \mu \mathrm{g}$ e de $2 \mathrm{H} 1-\mathrm{IgG} 3$ foi de $64 \mu \mathrm{g} . \mathrm{O} \mathrm{R}^{2}$ deste ELISA foi de 0,992.

$\mathrm{Na}$ tentativa de estimar a pureza dos anticorpos e confirmar sua quantificação, foi realizado SDS-PAGE. Inicialmente o gel foi corado por coomassie, mas a quantidade de 
amostras em $16 \mu \mathrm{L}$ não foi sufiente para produzir uma banda visível no gel, mesmo sendo obtidas após concentração em volume menor do que $1 \mathrm{~mL}$ (dado não mostrado). Dessa forma, o gel foi corado com nitrato de prata para avaliar se a amostra estava em concentração menor do que o ELISA sugeria (Figura 30). Foi utilizada amostra controle $18 \mathrm{~B} 7$ a 0,5 e 0,25 $\mu \mathrm{g}$. A intensidade das bandas de cadeia pesada dos anticorpos recombinantes indicou que os mesmos se encontravam $\leq 0,25 \mu \mathrm{g}$. Contaminantes foram evidenciados na amostra 4-4-20IgG1. As amostras estavam em condição desnaturante, como comprova a presença das cadeias pesadas $(\sim 50 \mathrm{kDa})$.

Figura 30 - SDS-PAGE de anticorpos 2H1 e 4-4-20 em condição desnaturante.

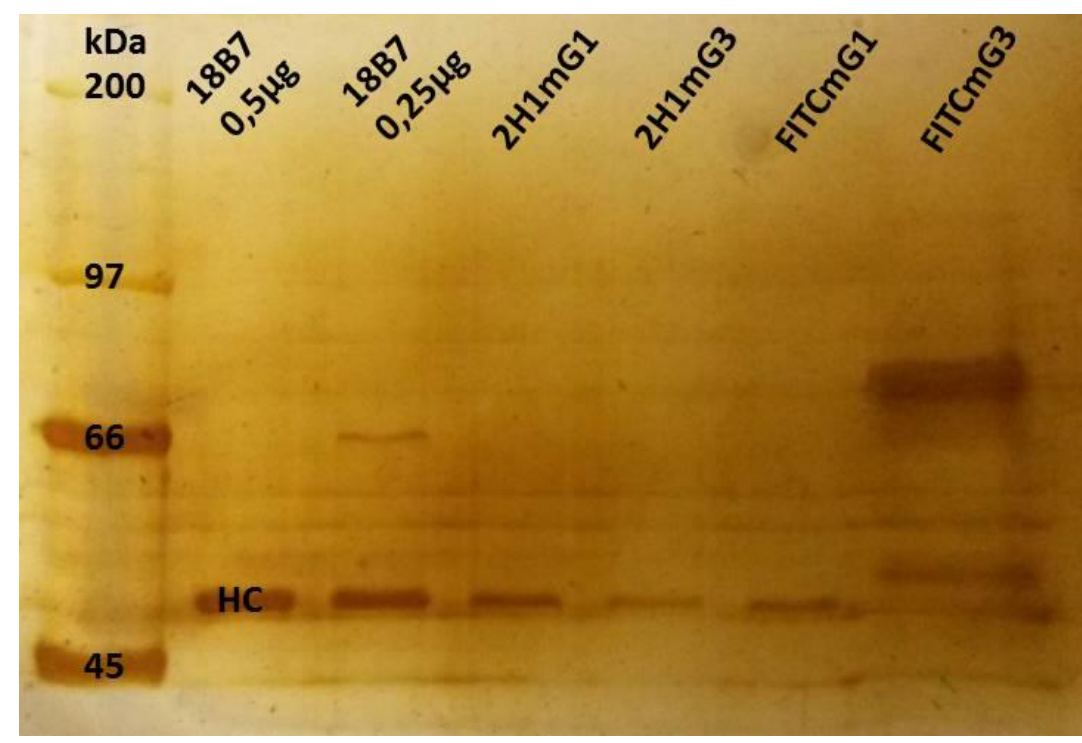

Anticorpos 2H1 e 4-4-20 tiveram o grau de pureza e quantificação avaliados por SDS-PAGE em condição desnaturante. A cadeia pesada dos anticorpos é evidenciada $(50 \mathrm{kDa})$. Os anticorpos recombinantes apresentaram quantificação menor do que $0,25 \mu \mathrm{g}$ em volume de aplicação de $16 \mu \mathrm{g}$. A amostra 4-4-20 apresentou bandas contaminantes. Para estimar a concentração dos anticorpos, foi utilizado $18 \mathrm{~B} 7$ a 0,5 e $0,25 \mu \mathrm{g}$. O marcador utilizado foi o Broad Range (Bio-Rad).

A estratégia alternativa de confirmar a quantificação do ELISA e do SDS-PAGE foi a de espectrofotometria por absorbância a UV280. A quantidade total de cada anticorpo, calculada a partir dos coeficientes de extinção molar definidos anteriormente, foia seguinte: 23,31 $\mu \mathrm{g}$ (2H1-IgG1), 16,66 $\mu \mathrm{g}$ (2H1-IgG3), 20,16 $\mu \mathrm{g}$ (4-4-20-IgG1) e 11,8 $\mu \mathrm{g}$ (4-4-20IgG3).A quantificação obtida por espectrofotometria reforçou a intensidade de bandas aumentadas de 2H1-IgG1 e 4-4-20-IgG1 quando comparadas à das bandas de 2H1-IgG3 e 44-20-IgG3 analisadas em SDS-PAGE anteriormente (Figura 30).

Experimentos de fagocitose com 2H1-IgG1 e 2H1-IgG3 foram realizados novamente para testar se com esse par de anticorpos seria observado o mesmo fenômeno de fagocitose 
mediada por ligação de IgG3 a um receptor desconhecido. Para tanto, foram utilizados bloqueadores de receptores Fc $\gamma$ e de complemento. A porcentagem de fagocitose de 2H1IgG1 antes e depois do bloqueio foi $27 \%$ e $0 \%$, respectivamente. Enquanto a porcentagem de fagocitose mediada por $2 \mathrm{H} 1-\mathrm{IgG} 3$ foi de $32 \%$ antes e $6 \%$ depois do bloqueio. O controle positivo com 18B7 em condição nãotratada com anticorpo de bloqueio apresentou porcentagem de fagocitose de $34 \%$, enquanto que a fagocitose na ausência de anticorpo resultou em 0\% (Figura $31 \mathrm{~A}$ ). Alguns dos campos visualizados por microscopia durante a contagem de macrófagos com $C$. neoformans internalizados foram selecionados para representar o percentual obtido (Figura $31 \mathrm{C}$ ). Repetição de fagocitose com células CHO se mostrou negativa (Figura $31 \mathrm{~B}$ ), reforçando o resultado obtido anteriormente (Figura $27 \mathrm{C}$ ).Os experimentos foram realizados em triplicada e apresentaram resultados estatisticamente significativos.

Figura 31- Fagocitose de C. neoformans H99 opsonizado com 2H1-IgG1 e 2H1-IgG3 por J774 e CHO-K1.

A)

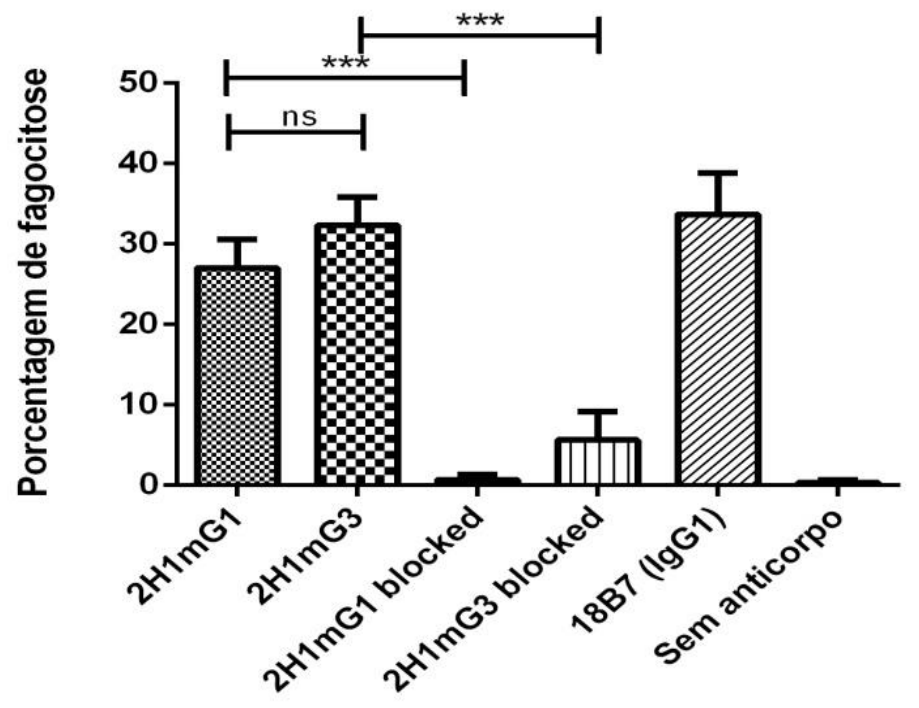

B)

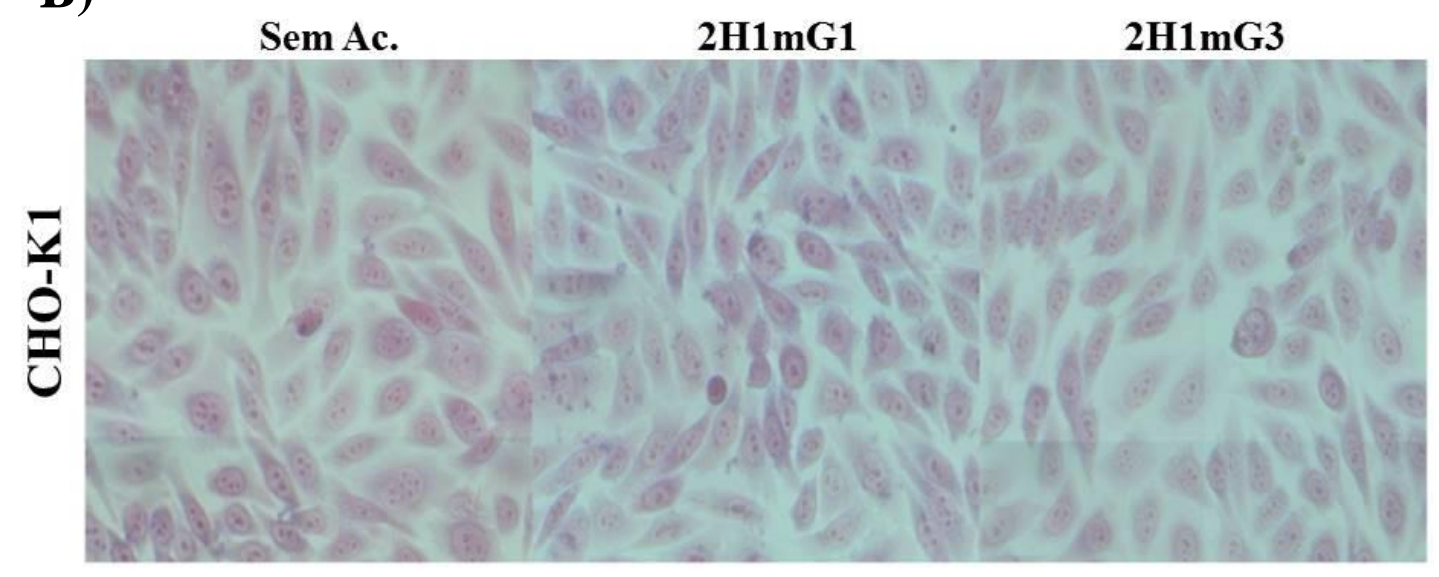


C)
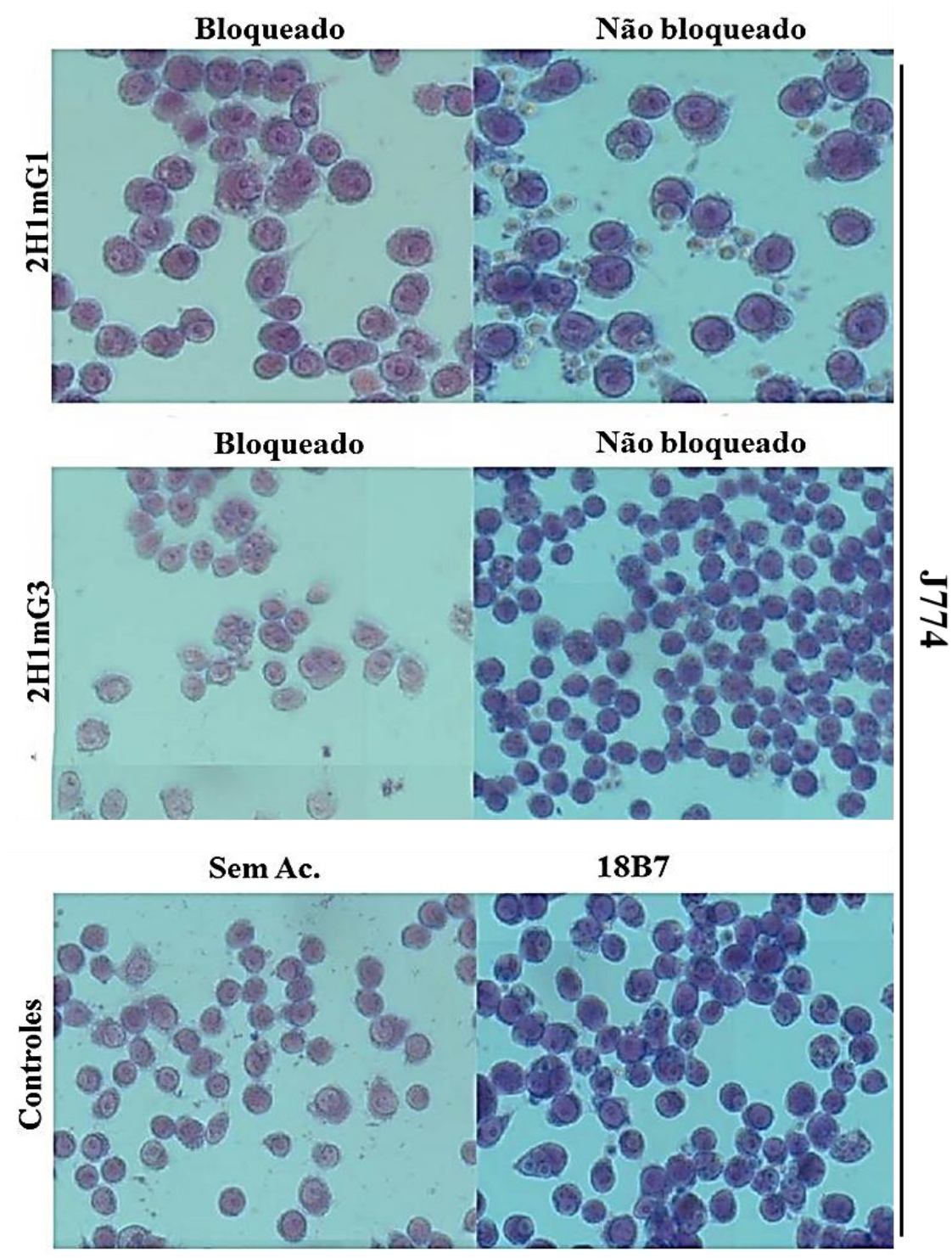

A) A porcentagem de fagocitose representa aquantificação das imagens microscópicas. O cálculo foi realizado contando 100 células $\mathbf{J} 774$ de, no mínimo,3 campos diferentes em três ensaios experimentais para cada condição. O número de células com C. neoformans H99 internalizados foi dividido pelo número total de macrófagos (100) para obter a porcentagem. $\mathrm{O}$ símbolo * representa que as comparações entre a porcentagem de fagocitose mediada por anticorpos recombinantes com receptores Fc e CR nãobloqueados e com receptores bloqueados foram estatisticamente significantes $(\mathrm{P}<0,05)$. O controle positivo $18 \mathrm{~B} 7$ e negativo (sem anticorpo) também validaram o experimento. B) Imagens de microscopia representativas de fagocitose por células CHO-K1 do fungo mediada pelos anticorpos $2 \mathrm{H} 1$, semelhante ao controle negativo (sem anticorpo). C) Imagens de microscopia de células coradas por Giemsarepresentativas do cálculo de fagocitose de ensaio com anticorpos $2 \mathrm{H} 1$ e controles. Os anticorpos foram utilizados na concentração de $1 \mu \mathrm{g} / \mathrm{mL}$.

A fim de testar se o mesmo achado de fagocitose mediada por interação de IgG3 com receptor desconhecido seria replicado com um tipo diferente de antígeno, preparamos imunocomplexos compostos por anticorpos 4-4-20 e BSA marcada duplamente com FITC e o corante sensível a pH pHrodo. Estes imunocomplexos foram incubados com células J774 por90 min. Caso os imunocomplexos fossem internalizados pelas células $\mathbf{J} 774$ e destinados ao sistema endolisossomal, o corante pHrodo ficaria fluorescente na cor vermelha.Foi observado 
que algumas células se tornaram vermelhas quando o BSA não estava marcado com FITC ou mesmo na ausência de anticorpo. Esse resutado pode ter sido devido à pinocitose de células J774, a qual pode ter resultado em internalização de BSA marcado com pHrodo no compartimento endolisossomal de forma independente de fagocitose. Isso significa que o controle negativo não foi completamente negativo e, portanto, existe quantidade razoável de ruído nos resultados experimentais que precisa ser eliminada com otimização dos parâmetros do experimento no futuro. Mesmo com esse ruído, o experimento rendeu resultados interessantes. Na presença de anticorpos 4-4-20IgG1 e IgG3, a porcentagem de células que internalizaram FITC-pHrodo-BSA ( $\operatorname{IgG1}=85 \%, \operatorname{IgG} 3=43 \%$ ) foi muito maior do que a do controle sem anticorpos (16\%). Quando anticorpos bloqueadores de Fc $\gamma \mathrm{R}$ foram adicionados, a fagocitose de $\operatorname{IgG} 1$ diminuiu como esperado (46\%), assim como a fagocitose mediada por IgG3 (25\%). Os anticorpos de bloqueio não aboliram a fagocitose, provavelmente devido ao ruído causado pela pinocitose de BSA marcado(Figura 32 A e B).

Figura 32 - Fagocitose de BSA marcado com FITC e pHrodo mediada por anticorpos 4-4-20IgG1/IgG3.

A)

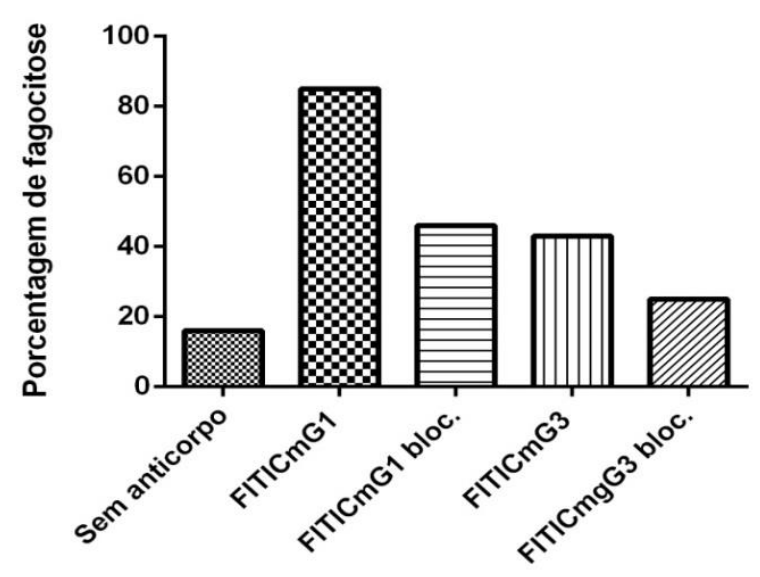


B)

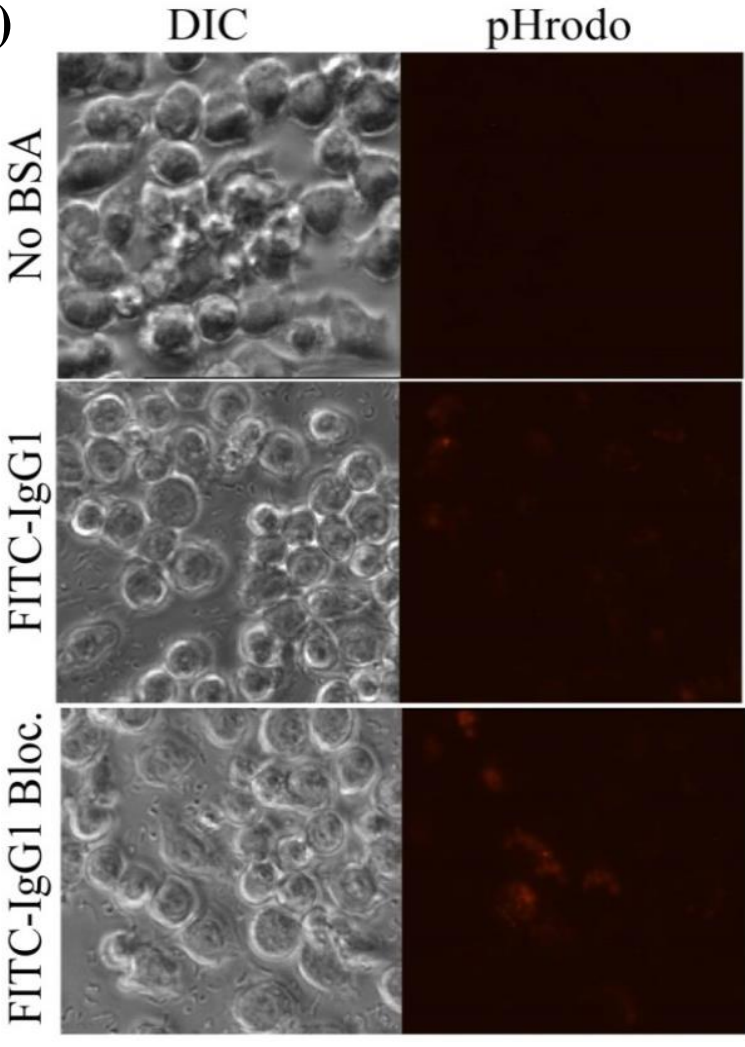

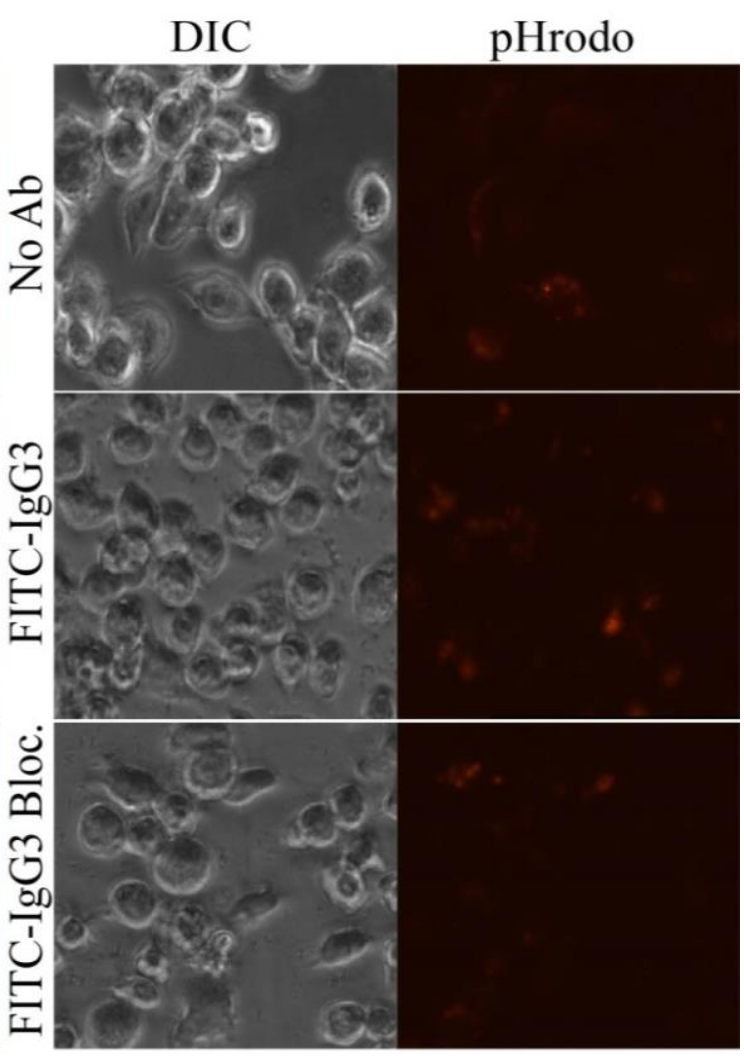

Fagocitose de imunocomplexo BSA marcado com FITC e pHrodo opsonizados com anticorpos 4-4-20-IgG1 e IgG3, sob condição de bloqueio ou não, por macrófagos J774 após 1,5 h de incubação. Os anticorpos foram utilizados a $1 \mu \mathrm{g} / \mathrm{mL}$. A) Porcentagem de células positivas parapHrodo em 100 células por condição. O controle negativo de fagocitose (sem anticorpo) evidencia que houve ruído no experimento. Embora o ruído estivesse presente, pode-se perceber que a porcentagem de fagocitose mediada por 4-4-20-IgG1 foi significante, assim como a de 4-4-20-IgG3. Quando os receptores Fc $\gamma$ de J774 foram bloqueados, houve decréscimo da porcentagem de $C$. neoformans $\mathrm{H} 99$ fagocitados. O teste não foi realizado em triplicata e, por isso, não pôde ser comprovada sua significância estatística. B) Imagens representativas do cálculo de fagocitose. Foram capturadas imagens em DIC de células J774 e fluorescentes por pHrodo.

A IFI foi feita incubando C. neoformans dos sorotipos H99 e 24067 com anticorpos (1 $\mu \mathrm{g} / \mathrm{mL}$ )2H1-IgG1, 2H1-IgG3 e 12A1, 13F1 que apresentam mesma cadeia constante e pequenas diferenças na cadeia variável, sendo eles utilizados como controle positivo para padrão anular e puntiforme, respectivamente. Como a concentração de anticorpos utilizada para o ensaio foi baixa, devido ao baixo rendimento do processo de purificação, a diferença no padrão de ligação não ficou muito evidente. Ainda assim, a MF revelou que a ligação de 2H1-IgG1 a GXM foi sugestiva de padrão anular, e a ligação de 2H1-IgG3, sugestiva de padrão puntiforme. O 13F1 se ligou com padrão puntiforme esperado, mas o padrão anular de 12A1 células 24067 não é muito evidente. As células 24067 e H99 apresentaram estrutura íntegra e com alguns brotamentos em microscopia de campo claro(Figura 33). 
Figura 33 - Ensaio de ligação dos anticorpos 2H1-IgG1/-IgG3 à cápsula de $C$. neoformans 24067 e H99.

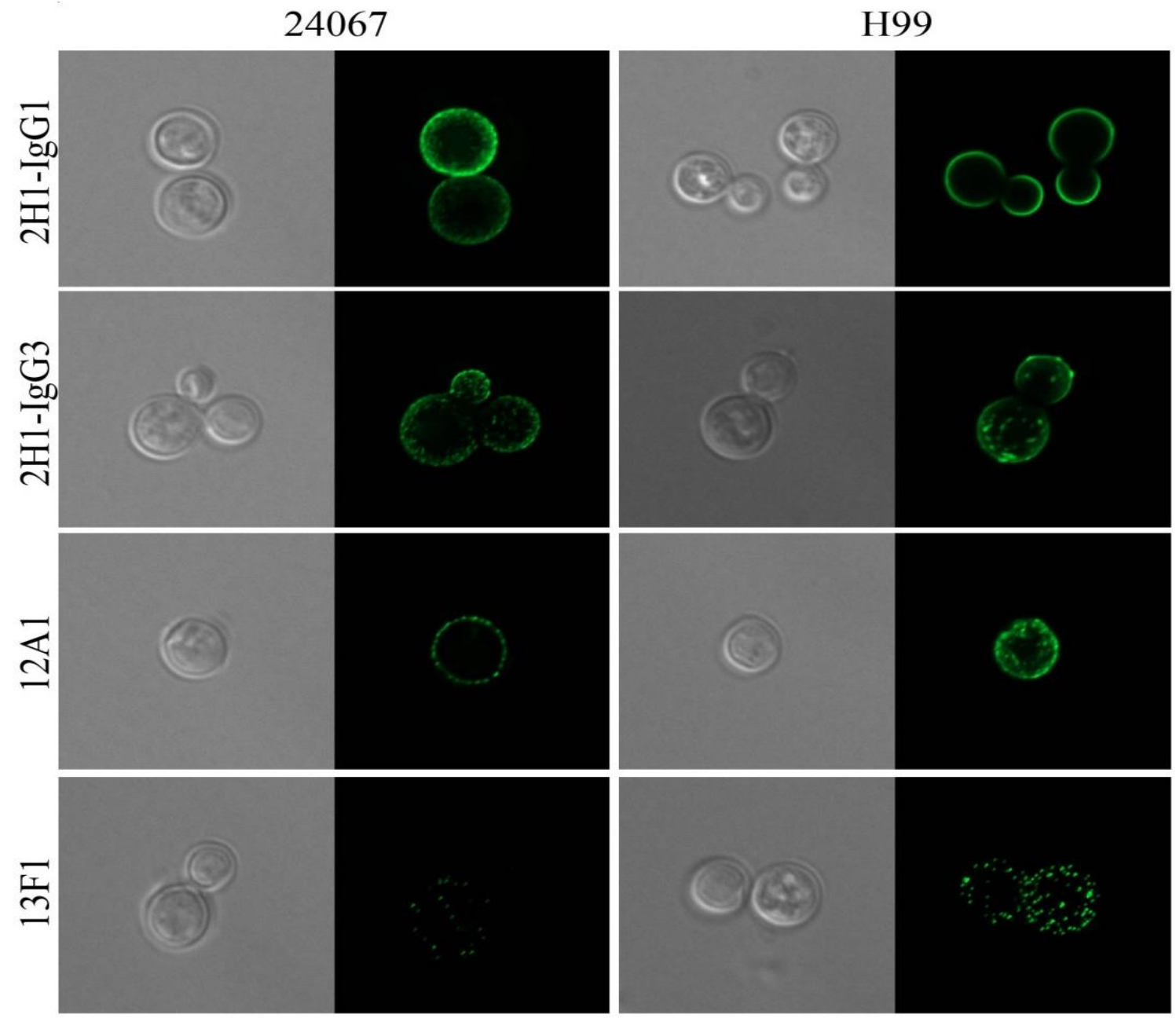

Imagens de microscopia de epifluorescência obtidas pelo Zeiss Axio Observer Z1 nas objetivas de 63X (NA 1,4). O padrão de ligação dos anticorpos à cápsula de C. neoformans H99 (sorotipo A) e 24067 (sorotipo D) foi avaliado. As imagens foram obtidas em campo claro por DIC e por MF. O teste foi realizado para avaliar o padrão de ligação dos anticorpos recombinantes $2 \mathrm{H} 1$ e o mesmo foi validado pelos controles positivos de padrão de ligação anular (12A1), puntiforme (13F1). Um controle com células marcadas somente com anticorpo secundário mostrou que não houve autofluorescência significativa (dado não mostrado). A concentração utilizada dos anticorpos primários foi de $1 \mu \mathrm{g} / \mathrm{mL}$. O anticorpo secundário utilizado foi anti-IgG de camundongo conjugado aAlexa Fluor ${ }^{\otimes} 488$ (ThermoFisher Scientific).

\subsection{PRODUÇÃO E TESTES DOTERCEIRO LOTE DE ANTICORPOS}

Anticorpos produzidos no terceiro lote foram 2H1-IgG1, 2H1-IgG3, 4-4-20-IgG1, 4-420-IgG3 em cultivo escalonado (de até $150 \mathrm{~mL}$ ) e crescimento em suspensão. Os sobrenadantes foram concentrados em membrana de celulose regenerada de $10 \mathrm{kDa}$ com concentrador Amicon ${ }^{\circledR}$ Stirred Cells (Millipore) epurificados por cromatografia de exclusão molecular.Para os anticorpos 2H1-IgG1 e 2H1-IgG3 foi realizado ELISA de GXM, além de SDS-PAGE para todos os anticorpos. 
A cromatografia de exclusão molecular foi realizada e, surpreendentemente, evidenciou pico com absorbância a UV280 próximo a 520 mAUpara 2H1-IgG1, e também gerou valores bem altos para purificação dos demais anticorpos. Os picos contaminantes não apresentaram condutividade muito alta, visto que não havia quantidade de sal residual, uma vez que as amostras não foram precipitadas com SAS (Figura 34).

Figura 34 - Gel filtração de 2H1-IgG1 após concentação por Amicon® Stirred Cells.

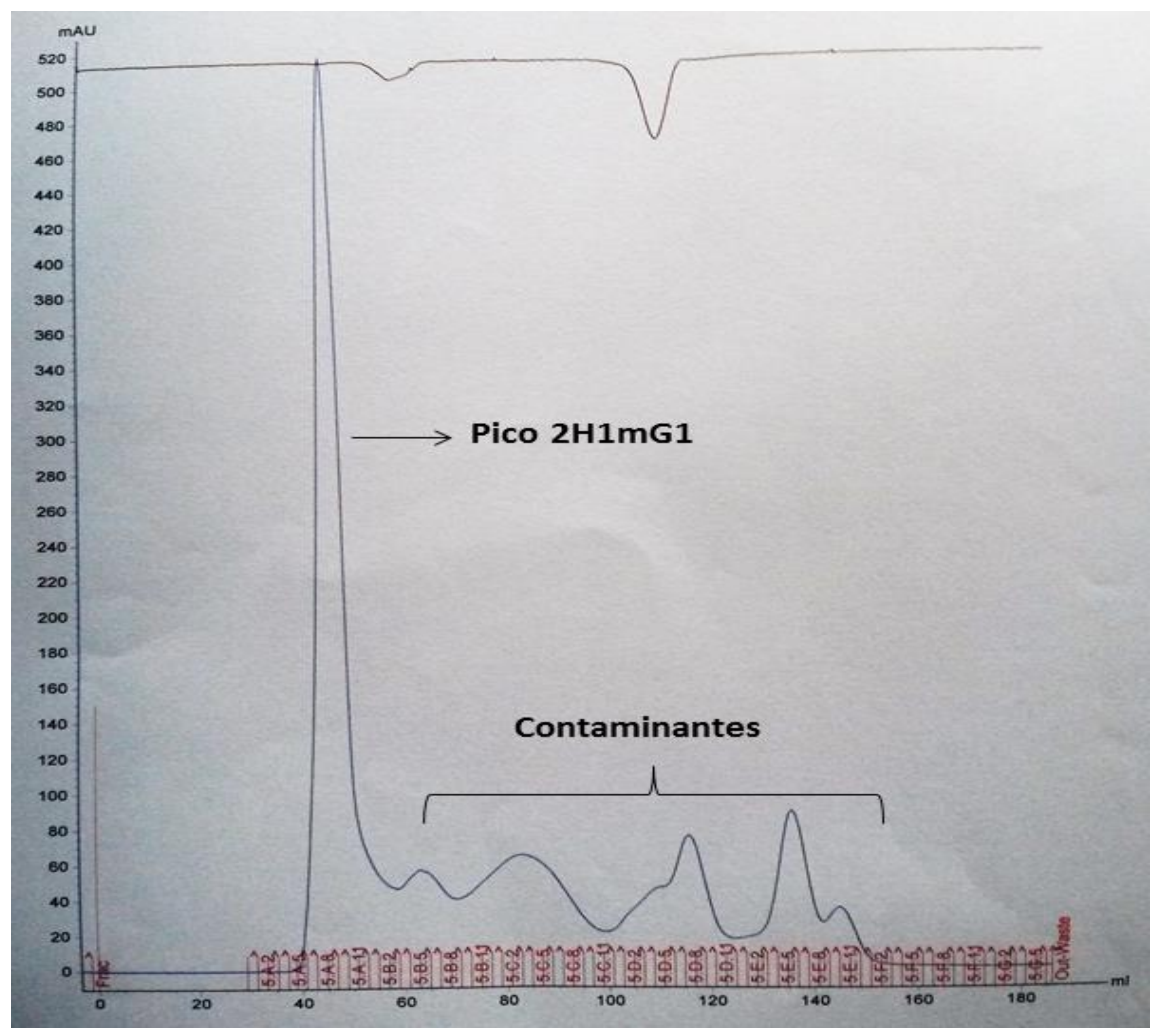

Cromatograma de 2H1-IgG1 obtido por cromatografia de exclusão molecular HiLoad 16/600 Superdex 75 pg em Akta Avant 25, evidencia pico de eluição da amostra com absorbânciapróximo a 520 mAU a UV280 e de contaminantes próximo a $100 \mathrm{mAU}$. A amostra apenas foi previamente ultrafiltrada usandoAmicon ${ }^{\circ}$ Stirred Cells (Millipore) em Ultrafiltration Discs, PLGC, Ultracel regenerated cellulose, $10 \mathrm{kDa}$ sob pressão constante de nitrogênio.

Quantificação de anticorpos 2H1 por ELISA resultou em $266 \mu \mathrm{g}$ totais de 2H1-IgG1 antes da injeção no cromatógrafo e $214 \mu \mathrm{g}$ após cromatografia. Quantidades bem baixas foram quantificadas para 2H1-IgG3 antes $(0,9 \mu \mathrm{g})$ e depois $(0,3 \mu \mathrm{g})$ da exclusão molecular (Figura 35). Novamente não foi possível quantificar as amostras de 4-4-20 por ELISA pela falta de padrão adequado para o ELISA. 
Figura 35 - Quantificação por ELISA de 2H1-IgG1 antes e após gel filtração.

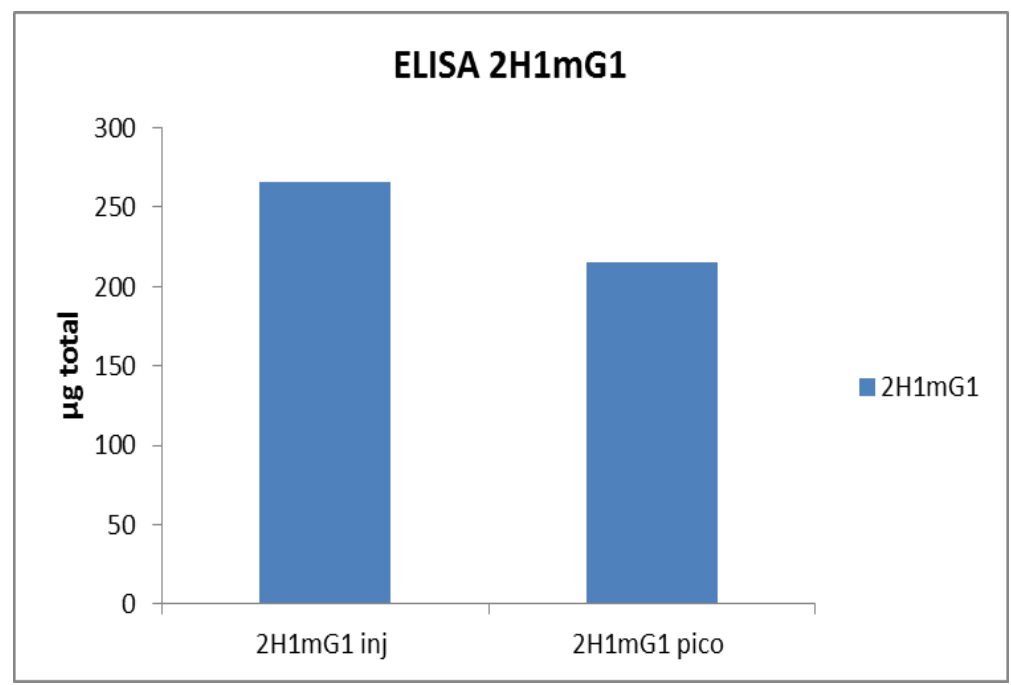

Anticorpos $2 \mathrm{H} 1$ foram quantificados antes e após exclusão molecular. 2H1-IgG3 apresentou quantidade insuficiente na deteç̧ão, enquanto $2 \mathrm{H} 1$ apresentou $214 \mu \mathrm{g}$ totais e perda de $52 \mu \mathrm{g}$ se comparado à concentração inicial de $266 \mu \mathrm{g}$. As concentrações de 2H1-IgG1antes (amostra injetada) e após a cromatografia foram de 55,2 $\mu \mathrm{g} / \mathrm{mL}$ e $14,3 \mu \mathrm{g} / \mathrm{mL}$ com volume final de $5 \mathrm{~mL}$ e $15 \mathrm{~mL}$, respectivamente. O R ${ }^{2}$ deste ELISA foi de 0,924 .

O resultado obtido na exclusão molecularresultou de retenção de contaminantes de maiores que $70 \mathrm{kDa}$ evidenciados em SDS-PAGE (Figura 36) corado com azul de coomassie. A amostra 2H1-IgG1 apresentou intensidade de banda próxima a 0,250 $\mu \mathrm{g} / \mathrm{mL}$, evidenciada em comparação com o controle positivo 18B7. A amostra 2H1-IgG3, assim como os anticorpos 4-4-20, apresentou banda de um provável contaminante com tamanho similaraoda cadeia pesada dos anticorpos.

Figura 36 - SDS-PAGE de anticorpos 2H1 e 4-4-20 após exclusão molecular.

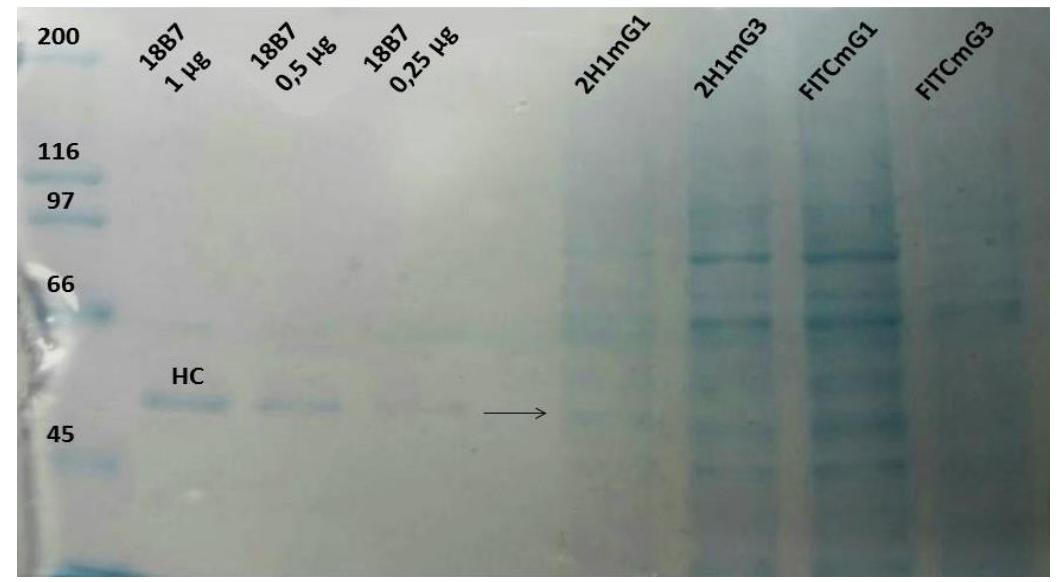

Anticorpos 2H1 e 4-4-20 tiveram sua pureza e concentração analisadas por SDS-PAGE corados por azul de coomassie. Baseado na corrida eletroforética de anticorpos $18 \mathrm{~B} 7 \mathrm{a} 1,0,5$ e $0,25 \mu \mathrm{g}$ em condição desnaturante, foi estimado que o anticorpo $2 \mathrm{H} 1$-IgG1 estivesse em concentração próxima a $0,25 \mu \mathrm{g}$ em $16 \mu 1$ de amostra aplicada, resultando em $234 \mu \mathrm{g}$ (em $15 \mathrm{~mL}$ de volume final). Apenas a cadeia constante dos anticorpos é evidenciada no gel. Os anticorpos recombinantes apresentaram contaminantes com massas molecularesentre $30 \mathrm{e}$ $70 \mathrm{kDa}$. O marcador utilizado foi o Broad Range (Bio-Rad). 


\section{DISCUSSÃO}

Para responder às perguntas importantes que propusemos estudar neste trabalho, foi necessário produzir anticorpos monoclonais recombinantes. Análises das construções de anticorpos geraram dados provenientes de fragmentos totais de nucleotídeos obtidos do sequenciamento, incluindo a região do inserto e a do vetor. Foi importante incluir a sequência do vetor na análise para avaliar se o inserto estava clonado no plasmídeo certo. Desta forma, os produtos do sequenciamento foram capazes de evidenciar a parte da cadeia constante pesada $(\mathrm{CH} 1)$ e da cadeia constante leve (Kappa) dos vetores. Os fragmentos apresentaram qualidade aceitável, segundo os critérios da ferramenta PHPH (174). O alinhamento de contigs com os construtos referência geraram algumas identidades nucleotídicas de $99 \%$, visto que foi considerada a região constante do vetor e que continha gaps. Já a análise de aminoácidos foi realizada apenas com as sequências dos insertos e, por isso, a identidade foi de $100 \%(175-177)$

Dois tipos de sistema de expressão foram considerados, o transiente (178) e o estável(179, 180). DNA clonado pode ser introduzido no núcleo de células de mamíferos por diversos métodos de transfecção, sendo capaz de persistir por vários dias e resultar em expressão transiente de genes presentes no vetor (178, 181-183). Alternativamente, a integração pode ser selecionada pelo uso de marcador gênico apropriado no vetor que o DNA será inserido randomicamente no genoma celular. Neste caso, o DNA é replicado com o genoma da célula hospedeira e uma linhagem de transfectante estável é produzida $(179,182$, 183). No entanto, investimento substancial em tempo e esforço (normalmente entre 6-12 meses) é requerido para produzir uma linhagem celular estavelmente transfectada, capaz de produzir grandes quantidades de anticorpos (184). Por outro lado, o sistema de expressão transiente é valioso por permitir a geração rápida de pequenas quantidades de anticorpos recombinantes $(178,183,185)$. Dessa forma, a expressão transiente justifica a produção variável entre clones $2 \mathrm{H} 1-\mathrm{IgG} 3 \mathrm{~T}-30$ e T-31, que a princípio foram os mais produtivos, e clones 2H1-IgG3 T3-4 e T3-5, que apresentaram maior produtividade na segunda quantificação.

Esse mesmo contexto de transfecção transiente justifica a baixa produtividade de anticorpos recombinantes obtida por células $\operatorname{NSO}(178,183,185)$. Ainda, as poucas células selecionadas foram adaptadas a crescimento livre de BSA, o que reduziu o crescimento celular e, provavelmente, a produtividade por dia de cultivo sob seleção(186). Células NSO, uma vez que são células secretoras (linfoblasto), crescem em alta densidade $\left(\sim 10^{7}\right.$ células $\left./ \mathrm{mL}\right)$ 
em condição de suspensão $(183,187)$. No entanto, os anticorpos recombinantes foram produzidos por células na ausência de agitação, o que pode ter contribuído para a baixa produtividade (187).

As células podem ser cultivadas como uma população misturada durante a seleção, gerando pool de células sobreviventes (182). As populações policlonais de células transfectadas podem render produtividade razoável se for usado um sistema de seleção rigoroso $(183,188)$. Para produção inicial de menores quantidades da proteína, os pools policlonais podem ser usados, contudo, a produtividade dos pools tende a diminuir conforme o tempo de cultivo $(182,183,188)$. Esse contexto justifica a maior quantificação de anticorpos 2H1 e 4-4-20-IgG3 provenientes de único clone do que obtidos em pool.

Anticorpos recombinantes 2H1-IgG1 e 4-4-20-IgG1, apesar de cultivados em pool, apresentaram maior produtividade que anticorpos IgG3. Uma das possíveis explicações para isso é a característica intrínseca ao anticorpo IgG3, que é a de se comportar como crioglobulina, dificultando sua recuperação e mensuração. Em termos de seu papel fisiológico, IgG3 de camundongo apresenta propensão a formar auto-agregação, a formar espontaneamente complexos pequenos e crioglobulinas $(152,189)$.

Quando comparada em condições prévias de seleção com antibiótico, a produtividade de célula $\mathrm{CHO}$ foi relativamente maior que a produtividade por célula NSO. Células $\mathrm{CHO}$ foram desenvolvidas como um sistema capaz de produzir grande quantidade de anticorpos (180, 183, 190). Porém, não foi possível fazer essa correlação após gerar pressão seletiva nas células. Apesar deste resultado, foi decidido que NSO seria, no momento, a melhor escolha para produção dos anticorpos, visto que não foi possível adaptar CHO a crescimento livre de soro. A maioria dos anticorpos recombinantes produzidos em larga escala tem sido gerada usando mielomas (183).

A eficiência de transfecção dos vetores $2 \mathrm{H} 1$ e 4-4-20 por lipofectamina e K2 foi semelhante, porém instável. Esse resultado era esperado, visto que ambos os reagentes de transfecção utilizados são lipídeos catiônicos $(190,191)$. A estrutura básica dos lipídeos catiônicos consiste de uma região positivamente carregada ligada à cadeia de hidrocarbonetos. A carga positiva medeia a interação entre os lipídeos e os grupamentos fosfato dos ácidos nucléicos, facilitando a condensação do DNA. A carga positiva dos lipossomos, então, medeia a interação dos ácidos nucléicos com a célula através de endocitose $(192,193)$.

Uma vez que a purificação dos anticorpos recombinantes pelo método convencional de proteína G (194) não funcionou,assim como outros métodos de purificação, o método de escolha foi o intercâmbio aniônico por DEAE (168), seguido por precipitação com solução 
saturada SAS(167). Os anticorpos apresentaram boa recuperação pelos métodos, e houve perda maior de proteína durante a ultracentrifugação. Trabalho anterior sobre ensaio de ligação entre anticorpos monoclonais 3E5 e receptor Fc $\gamma$ realizou purificação e precipitação pelos mesmos métodos descritos(151). Amostra analisada em SDS-PAGE após ultrafiltração, evidenciou que a diálise foi insuficiente para remoção de sal, devido ao padrão de migração irregular observado (195). Distorção no gradiente de $\mathrm{pH}$ pode alterar o padrão de separação da amostra (196), gerando distorção de banda, produção de artefatos, ou aumentar ruído na coloração do gel (195). A fim de remover o sal proveniente da precipitação, o método de cromatografia por exclusão molecular, de forma geral, mostrou-se eficiente em eliminar contaminantes de massa molecular menor do que $70 \mathrm{kDa}$ e em separar complexos protéicos não covalentes $(169,180)$.

Embora os macrófagos sejam o principal tipo celular do sistema imune inato responsável pela defesa do organismo hospedeiro contra $C$. neoformans, o fungoé incapaz de ser fagocitado sem a presença de opsoninas, uma vez que a cápsula polissacarídica inibe o mecanismo fagocítico(80, 197, 198). Os anticorpos são importantes mediadores da fagocitose, por se comportarem como uma ponte de interação entre o antígeno e a célula fagocítica para permitir a eliminação do patógeno $(147,148,199)$. Dessa forma, a funcionalidade do anticorpo pode ser avaliada mediando fagocitose de C. neoformans por macrófagos in vitro, uma vez que o mecanismo é dependente da interação do anticorpo com receptor Fc $\gamma \mathrm{R}$ celular(148, 161, 162, 200). Interação direta de IgG1 complexado ao antígeno com receptor Fc $\gamma$ pode mediar a morte ou inibir o crescimento fúngico por citotoxicidade dependente de anticorpo, mediada por macrófago ou células Natural Killer(147, 148, 200). Além disso, o sistema in vitro é vantajoso porque, na ausência de opsonina, a fagocitose do fungo é essencialmente zero, e as células leveduriformes, quando fagocitadas, são facilmente identificadas e contadas por microscopia $(73,153,201)$.

A funcionalidade da região $\mathrm{Fc}$ de $2 \mathrm{H} 1$ foi evidenciada nos três ensaios de fagocitose de C. neoformans por macrófagos J774. Foi previamente reportado que 2H1(202), 18B7, 12A1(150), 3E5 (IgG1) (81)apresentaram maiores porcentagens de fagocitose, se comparados aos anticorpos 13F1 (150)e 3E5 (IgG3)(81). No ensaio piloto, anticorpos 2H1-IgG3 evidenciaram fagocitose em porcentagem relativamente baixa se comparada a fagocitose mediada por 18B7, mas que concorda com dados da literatura(81). No entanto, os dois ensaios posteriores com anticorpos $2 \mathrm{H} 1-\mathrm{IgG} 3$ evidenciaram porcentagens semelhantes ou superioresa de anticorpos 2H1-IgG1 e 18B7(153).Esse resultado contrasta com dados da literatura, que relatam que os isotipos IgG 3E5 variam na eficácia em promover fagocitose, apresnetando a 
relação IgG2b > IgG1 > IgG3 (81). No entanto, os anticorpos 3E5 (81)foram produzidos por hibridoma e purificados de líquido ascítico, o que pode acarretar certas diferenças no processamento pós-traducional dos anticorpos recombinates produzidos in vitroem meio livre de soro e, consequente, interferir na função biológica dos mesmos (203). Sabe-se que modificações pós-traducionais, como glicosilação, são importantes na modulação da função efetora do anticorpo (183).

Anticorpos 2H1-IgG3 mostraram menor dependência de receptores Fc $\gamma$ e CR que anticorpos 2H1-IgG1, na fagocitose de C. neoformans H99 após uso de anticorpos de bloqueio. Esse resultado corrobora informações da literatura de que o isotipo IgG3 apresenta receptor diferente dos demais isotipos $\mathrm{IgG}$, segundo experimentos realizados com mAb 3E5 de hibridoma(153). Apesar da dependência de IgG3 aos receptores ter sido demonstrada, diferentemente da de IgG1, a eficácia de fagocitose mediada por IgG3 foi consideravelmente reduzida quando os receptores foram bloqueados. Esse dado também reforça que IgG3 foi também dependente de Fc $\gamma$ e CR, mas não de forma exclusiva, como apresentado por um trabalho australiano, que utiliza anticorpos IgG3 contra hemácias de carneiro e descreve Fc $\gamma$ RI como provável receptor de IgG3 de camundongo (152).

A fagocitose de C. neoformans opsonizado com 2H1-IgG3 não ocorreu nos dois ensaios com célula CHO-K1. Dessa forma, não foi possível reproduzir o resultado de fagocitose do fungo mediada pela interação entre Integrina beta 1 e IgG3 por estas células(172). Existem, portanto, três tipos de resultados de fagocitose com anticorpos IgG3:

1. Saylor e colaboradores(153) usaram anticorpos 3E5 produzidos por hibridoma e purificados de líquido ascítico. Com esses anticorpos, eles obtiveram bloqueio negligível da fagocitose mediada por IgG3 quando os receptores Fc $\gamma$ foram bloqueados, o que significa que a fagocitose deve ter sido primariamente mediada pelo receptor desconhecido e muito pouco por Fc $\gamma \mathrm{RI}$.

2. Gavin e colaboradores (152) usaram anticorpos contra hemácias de carneiro, também produzidos por hibridoma e purificados de líquidoascítico, mas utilizando células diferentes das usadas na geração de 3E5. Com esses anticorpos, eles observaram abolição completa da fagocitose quando FcyRI foi bloqueado, indicando que esses anticorpos interagiram principalmente com Fc $\gamma$ RI e muito pouco com o receptor desconhecido.

3. Neste trabalho, observamos um comportamento intermediário entre os dois observados anteriormente. Bloqueio de receptores Fc $\gamma$ diminuiu bastante a fagocitose por 2H1-IgG3, mas não a aboliu completamente. 
Uma hipótese interessante para explicar essas diferenças na interação de IgG3 com Fc $\gamma$ RI ou o receptor desconhecido é que a interação com cada tipo de receptor depende de variações na modificação pós-traducional dos anticorpos, que difere de forma não completamente previsível em diferentes lotes e dependendo da forma como o anticorpo foi produzido. Nosso grupo está preparando experimentos para testar essa hipótese.

Os anticorpos 4-4-20 contra FITC também apresentaram funcionalidade da região Fc em ensaios de fagocitose de BSA marcado. Esse resultado foi evidente mesmo com ruído vermelho (pHrodo) internalizado nas células J774, que provavelmente foi gerado por pinocitose intrínseca de BSA marcado pelos macrófagos (204). Pinocitose ocorre em todas as células, incluindo macrófagos, para obtenção de nutrientes e mediadores biológicos, abrangendo mais comumente partículas e moléculas menores (até $\sim 120 \mathrm{~nm}$ ), assim como de diâmetros maiores (macropinocitose $100 \mathrm{~nm}$ a $5 \mu \mathrm{m})(204,205)$. A porcentagem de fagocitose mediada por IgG1 foi maior do que a mediada por IgG3, como esperado (153). Quando as células tiveram os receptores Fc $\gamma$ bloqueados foi observada redução de aproximadamente $50 \%$ da porcentagem de fagocitose de ambos os isotipos de anticorpos 4-4-20. Era esperado maior dependência do anticorpo $\operatorname{IgG1}$ aos receptores convencionais, no entanto, não foi possível fazer esta avaliação devido ao ruído mencionado (204). Em experimentos futuros pretendemos utilizar no lugar de BSA, hemácias de carneiro conjugadas a FITC (151).

O sítio de ligação ao antígeno dos anticorpos é formado por regiões determinantes de complementariedade (CDR) $(143,144)$ e sua especificidade e afinidade são definidas por variações em sua sequência e estrutura $(142,149,206)$. A combinação da grande cápsula polissacarídica e da disponibilidade de anticorpos monoclonais específicos contra ela, torna $C$. neoformans o sistema de escolha para estudo das interações anticorpo-antígeno (29)mediada pela região variável. Anticorpos 2H1, 18B7, 12A1, 13F1 e 3E5 apresentaram ligação à cápsula de $C$. neoformans em ensaios de imunofluorescência relatados na literatura, o que evidenciou a funcionalidade da região variável dos mesmos $(29,30,135,145,150)$. Os anticorpos recombinantes $2 \mathrm{H} 1$ deste estudo apresentaram funcionalidade da cadeia variável em testes de IFI por ligação específica à GXM de C. neoformans sorotipo A (H99) e D (24067), e também apresentaram especificidade por ELISA.

Anticorpos monoclonais se ligam de forma anular ou puntiforme à cápsula do fungo em experimentos de IFI $(32,81,150)$. Embora o mecanismo seja desconhecido, diferenças no padrão de imunofluorescência indicam ligação a diferentes epitopos e também implicam na localização do epitopo na estrutura capsular, sendo também dependente da classificação do sorotipo(31). Anticorpos 2H1, 18B7, 12A1 e 3E5 (IgG1) apresentam padrão de fluorescência 
anular aos sorotipos A (H99) e D (24067) de C. neoformans; enquanto que anticorpos 13F1 apresentam padrão puntiforme ao sorotipo D e anular ao sorotipo A, e 3E5 (IgG3) apresenta padrão puntiforme ao sorotipo $\mathrm{D}(31,145,150)$.

Os anticorpos 2H1 recombinantes apresentaram padrão de ligação anular (IgG1) e puntiforme (IgG3), quando utilizados contra GXM de C. neoformans sorotipo A e D (145). Teste piloto com 2H1-IgG3 não purificado apresentou padrão de ligação puntiforme contra H99, assim como o de 3E5 IgG3 relatado previamente (145). O ensaio utilizou 4-4-20-IgG3 (controle negativo) e 18B7 (controle positivo), que não gerou fluorescência e que gerou padrão de fluorescência anular respectivamente, confirmando dados da literatura (150).

Teste com anticorpos 2H1 recombinantes e purificados contra GXM de H99 e 24067 apresentou padrão de fluorescência evidente, porém sutilmente diferentes entre os sorotipos. $\mathrm{O}$ anticorpo 2H1-IgG1 apresentou padrão anular e 2H1-IgG3 padrão puntiforme entre os dois sorotipos. O controle 13F1 apresentou padrão puntiforme por ligação em ambos os sorotipos, enquanto que 12A1 apresentou padrão anular evidente no sorotipo A e padrão puntiforme, inesperado no sorotipo D. Esse padrão inesperado pode ter sido proveniente da baixa concentração de anticorpos utilizados no experimento $(1 \mu \mathrm{g} / \mathrm{mL})$, se comparada à concentração de anticorpos utilizada comumente nos experimentos relatados na literatura (5$10 \mu \mathrm{g} / \mathrm{mL})(29,30,150)$. O uso desta concentração mais baixa nos nossos testes foi devido à dificuldade em produzir quantidade suficiente de anticorpos para a realização de todos os ensaios. Estamos trabalhando na geração de mais anticorpos para repetir o teste uma vez mais, com uma variedade de concentrações diferentes. Outra possibilidade para o padrão de ligação inesperado de $12 \mathrm{~A} 1$, é que o sorotipo $\mathrm{D}$ poderia estar em fase de crescimento estacionária(31).

É observado que anticorpos IgG3 que se ligam por padrão puntiforme estão relacionados a imunidade não protetora, enquanto anticorpos IgG1 que se ligam por padrão anular apresentam resposta imune protetora evidenciada por experimentos de fagocitose e de sobrevivência de camundongos infectados com $C$. neoformans tratados com os anticorpos $(24,28-30,32,135,150,155)$. Correlacionando os resultados de padrão de ligação e fagocitose de anticorpos $2 \mathrm{H} 1$ recombinantes, foi possível observar que o padrão anular obtido por 2H1-IgG1 correspondeu à imunidade protetora mediada por macrófagos em fagocitose eficaz de C. neoformans. No entanto, não foi possível correlacionar o padrão puntiforme de 2H1-IgG3 com a eficácia fagocítica obtida no experimento in vitro, mas sim com resultado da literatura, que mostrou que IgG3 3E5 apresentou eficácia protetora mediada por fagocitose semelhante à de IgG1 (153). Experimentos com camundongos infectados com C. neoformans 
e tratados com esses anticorpos recombinantes poderão revelar se a mudança de IgG1 para IgG3 nos anticorpos 2H1 também transforma um anticorpo protetor em não protetor.

A visão clássica quanto à função dos anticorpos postula dois domínios, definidos pelas regiões variável e constante, que são responsáveis pela ligação ao antígeno e função efetora, respectivamente $(34,35)$. Várias evidências sugerem que diferenças nas sequências de $\mathrm{CH}$ podem afetar a especificidade e afinidade do anticorpo ao seu antígeno(141, 142, 159). Um exemplo são os isotipos IgG1 e IgG3 monoclonais 3E5 de hibridoma, os quais apresentam regiões variáveis idênticas, mas padrão de ligação a $C$. neoformans em IFI,respectivamente, anular e puntiforme $(28-30,145)$. O resultado de padrão de ligação obtido pelo anticorpo recombinante com região variável do anticorpo monoclonal 2H1 (originalmente de $\operatorname{IgG} 1$ ) foi alterado de anular para puntiforme, quando a cadeia constante IgG1 foi trocada pela cadeia constante de IgG3. Esse resultado reforça o único dado anteriormente obtido com isotipos $\operatorname{IgG}(145)$, sendo este pela primeira vez realizado com o par de anticorpos recombinantes IgG1 e IgG3. Mais importante, o fato de produzirmos esses anticorpos por engenharia genética permite a manipulação das sequências que codificam os anticorpos a fim de descobrir qual parte da região constante de IgG3 altera a estrutura do paratopo (137). Com este objetivo, já produzimos vetores em que anticorpos de um isotipo têm pequenas regiões substituídas pela região equivalente do outro isotipo. Por exemplo, os anticorpos (a) IgG1 com o domínio de dobradiça substituiído pelo de IgG3 e (b) IgG3 com o domínio de dobradiça substituído pelo de IgG1, permitirão testar se é a mobilidade da dobradiça que altera a estrutura fina do domínio VH. Os vetores para expressão destes anticorpos já foram feitos (Figura 13) e serão utilizados em experimentos futuros. 


\section{CONCLUSÃO}

Neste trabalho, mostramos resultados que demonstram a produção, com sucesso, de quatro anticorpos monoclonais recombinantes que apresentaram funcionalidade tanto em testes de interação com o antígeno (IFI e ELISA), quanto em testes de interação com receptores de Fc (ensaio de fagocitose com macrófagos J774). Em testes de IFI demonstramos que o padrão de ligação de anticorpos $2 \mathrm{H} 1$ foi semelhante ao observado anteriormente para 3E5, sendo anular para IgG1 e puntiforme para IgG3. Essa alteração no padrão de fluorescência observada em um segundo par de IgGs reforça a informação que a região constante de anticorpos altera a região variável e, consequentemente, sua ligação ao antígeno. Nossa estratégia experimental usando anticorpos monoclonais recombinantes fornece novas ferramentaspara estudos que serão realizados pelo nosso grupo de pesquisa com finalidade de localizar com precisão quais regiões da cadeia constante alteram a especificidade e funcionalidade de um anticorpo.Tal informação pode ser bastante útil no desenvolvimento de anticorpos terapêuticos mais eficazes.

$\mathrm{O}$ anticorpo 2H1-IgG1 apresentou dependência completa dos receptores Fc $\gamma$ para mediar fagocitose, enquanto 2H1-IgG3 apresentou também dependência dos receptores convencionais, mas não de forma exclusiva. Este dado de 2H1-IgG3demonstra, com um novo anticorpo,o achado de alguns grupos de pesquisa que concordam que este isotipo pode até interagir com os receptores convencionais,mas que também exerce função efetora por outro receptor ainda desconhecido. A versatilidade provida pelo modelo de anticorpos monoclonais recombinantes também nos permitirá obter ferramentas para estudar a interação entre IgG3 e este receptor desconhecido eainda,conhecer o resultado funcional dessa interação na resposta imunitária. 


\section{PERSPECTIVAS}

A fim de responder perguntas importantes que surgiram com os resultados deste trabalho, será necessário ao entendimento do mecanismo funcional dos anticorpos recombinantes $2 \mathrm{H} 1$ investigar:

- Se há diferença no padrão de glicosilação de anticorpos produzidos por células NSO (2H1 IgG1 e IgG3) e de anticorpos de hibridoma produzidos em líquido ascítico (3E5 IgG1 e IgG3), por espectrometria de massa;

- Qual região da cadeia constante entre isotipos IgG1 e IgG3 é responsável por alterar o paratopo, utilizando engenharia genética para construção de anticorpos quiméricos;

- Investigar se anticorpos 3E5 e 2H1 competem pelo mesmo epítopo de GXM, por ELISA de competição;

- Investigar,utilizando ressonância plasmônica de superfície, a biofísica da interação entreIgG3e a Integrina b-1, proteína candidata a ser o receptor desconhecido de IgG3 baseado em dados de experimentos de perda e ganho de função.

Estas investigações foram propostas como projeto de doutorado aprovado na seleção do doutorado em Biologia Molecular da UnB. 


\section{REFERÊNCIAS BIBLIOGRÁFICAS}

1. Idnurm A, Bahn YS, Nielsen K, Lin X, Fraser JA, Heitman J. Deciphering the model pathogenic fungus Cryptococcus neoformans. Nat Rev Microbiol. 2005;3(10):753-64.

2. Srikanta D, Santiago-Tirado FH, Doering TL. Cryptococcus neoformans: historical curiosity to modern pathogen. Yeast. 2014;31(2):47-60.

3. Gullo FP, Rossi SA, Sardi Jde C, Teodoro VL, Mendes-Giannini MJ, Fusco-Almeida AM. Cryptococcosis: epidemiology, fungal resistance, and new alternatives for treatment. Eur J Clin Microbiol Infect Dis. 2013;32(11):1377-91.

4. WHO. Revised Global Burden of Disease (GBD) 2002 Estimates 2002. Available from: http://www.who.int/healthinfo/bodgbd2002revised/en/index.html.

5. Hakim JG, Gangaidzo IT, Heyderman RS, Mielke J, Mushangi E, Taziwa A, et al. Impact of HIV infection on meningitis in Harare, Zimbabwe: a prospective study of 406 predominantly adult patients. AIDS (London, England). 2000;14(10):1401-7.

6. Chariyalertsak S, Sirisanthana T, Saengwonloey O, Nelson KE. Clinical presentation and risk behaviors of patients with acquired immunodeficiency syndrome in Thailand, 1994--1998: regional variation and temporal trends. Clinical infectious diseases : an official publication of the Infectious Diseases Society of America. 2001;32(6):955-62.

7. Park BJ, Wannemuehler KA, Marston BJ, Govender N, Pappas PG, Chiller TM. Estimation of the current global burden of cryptococcal meningitis among persons living with HIV/AIDS. Aids. 2009;23(4):525-30.

8. Lin X, Heitman J. The biology of the Cryptococcus neoformans species complex. Annual review of microbiology. 2006;60:69-105.

9. Del Valle L, Pina-Oviedo S. HIV disorders of the brain: pathology and pathogenesis. Frontiers in bioscience : a journal and virtual library. 2006;11:718-32.

10. Martins Mdos A, Brighente KB, Matos TA, Vidal JE, Hipolito DD, Pereira-Chioccola VL. Molecular diagnosis of cryptococcal meningitis in cerebrospinal fluid: comparison of primer sets for Cryptococcus neoformans and Cryptococcus gattii species complex. Braz J Infect Dis. 2015;19(1):62-7. 11. Vidal JE, Penalva de Oliveira AC, Dauar RF, Boulware DR. Strategies to reduce mortality and morbidity due to AIDS-related cryptococcal meningitis in Latin America. The Brazilian journal of infectious diseases : an official publication of the Brazilian Society of Infectious Diseases. 2013;17(3):353-62.

12. Giacomazzi J, Baethgen L, Carneiro LC, Millington MA, Denning DW, Colombo AL, et al. The burden of serious human fungal infections in Brazil. Mycoses. 2015.

13. Cogliati M. Global Molecular Epidemiology of Cryptococcus neoformans and Cryptococcus gattii: An Atlas of the Molecular Types. Scientifica (Cairo). 2013;2013:675213.

14. Mirza SA, Phelan M, Rimland D, Graviss E, Hamill R, Brandt ME, et al. The changing epidemiology of cryptococcosis: an update from population-based active surveillance in 2 large metropolitan areas, 1992-2000. Clinical infectious diseases : an official publication of the Infectious Diseases Society of America. 2003;36(6):789-94.

15. Cogliati M, Esposto MC, Clarke DL, Wickes BL, Viviani MA. Origin of Cryptococcus neoformans var. neoformans diploid strains. Journal of Clinical Microbiology. 2001;39(11):3889-94.

16. Lengeler KB, Cox GM, Heitman J. Serotype AD strains of Cryptococcus neoformans are diploid or aneuploid and are heterozygous at the mating-type locus. Infection and Immunity. 2001;69(1):115-22.

17. Franzot SP, Salkin IF, Casadevall A. Cryptococcus neoformans var. grubii: separate varietal status for Cryptococcus neoformans serotype A isolates. Journal of Clinical Microbiology. 1999;37(3):838-40. 
18. Antinori S. New Insights into HIV/AIDS-Associated Cryptococcosis. Isrn aids. 2013;2013:471363.

19. Heiss C, Klutts JS, Wang Z, Doering TL, Azadi P. The structure of Cryptococcus neoformans galactoxylomannan contains beta-D-glucuronic acid. Carbohydr Res. 2009;344(7):915-20.

20. Nakouzi A, Zhang T, Oscarson S, Casadevall A. The common Cryptococcus neoformans glucuronoxylomannan M2 motif elicits non-protective antibodies. Vaccine. 2009;27(27):3513-8.

21. Perfect JR, Casadevall A. Cryptococcosis. Infectious disease clinics of North America. 2002;16(4):837-74, v-vi.

22. Yuan RR, Casadevall A, Oh J, Scharff MD. T cells cooperate with passive antibody to modify Cryptococcus neoformans infection in mice. Proceedings of the National Academy of Sciences of the United States of America. 1997;94(6):2483-8.

23. Casadevall A, Mukherjee J, Devi SJ, Schneerson R, Robbins JB, Scharff MD. Antibodies elicited by a Cryptococcus neoformans-tetanus toxoid conjugate vaccine have the same specificity as those elicited in infection. J Infect Dis. 1992;165(6):1086-93.

24. Mukherjee J, Scharff MD, Casadevall A. Protective murine monoclonal antibodies to Cryptococcus neoformans. Infection and Immunity. 1992;60(11):4534-41.

25. Larsen RA, Pappas PG, Perfect J, Aberg JA, Casadevall A, Cloud GA, et al. Phase I evaluation of the safety and pharmacokinetics of murine-derived anticryptococcal antibody $18 B 7$ in subjects with treated cryptococcal meningitis. Antimicrobial Agents and Chemotherapy. 2005;49(3):952-8.

26. Lendvai N, Casadevall A. Monoclonal antibody-mediated toxicity in Cryptococcus neoformans infection: mechanism and relationship to antibody isotype. J Infect Dis. 1999;180(3):791-801.

27. Savoy AC, Lupan DM, Manalo PB, Roberts JS, Schlageter AM, Weinhold LC, et al. Acute lethal toxicity following passive immunization for treatment of murine cryptococcosis. Infection and Immunity. 1997;65(5):1800-7.

28. Cleare W, Brandt ME, Casadevall A. Monoclonal Antibody 13F1 Produces Annular Immunofluorescence Patterns on Cryptococcus neoformans Serotype AD Isolates. Journal of Clinical Microbiology. 1999;37(9):3080.

29. Feldmesser $M$, Rivera J, Kress $Y$, Kozel TR, Casadevall A. Antibody interactions with the capsule of Cryptococcus neoformans. Infection and Immunity. 2000;68(6):3642-50.

30. Nussbaum G, Cleare W, Casadevall A, Scharff MD, Valadon P. Epitope Location in the Cryptococcus neoformans Capsule Is a Determinant of Antibody Efficacy. The Journal of Experimental Medicine. 1997;185(4):685-94.

31. Cleare $\mathrm{W}$, Casadevall $\mathrm{A}$. The different binding patterns of two immunoglobulin $\mathrm{M}$ monoclonal antibodies to Cryptococcus neoformans serotype $A$ and D strains correlate with serotype classification and differences in functional assays. Clinical and diagnostic laboratory immunology. 1998;5(2):125-9.

32. Mukherjee J, Kozel TR, Casadevall A. Monoclonal antibodies reveal additional epitopes of serotype D Cryptococcus neoformans capsular glucuronoxylomannan that elicit protective antibodies. Journal of immunology (Baltimore, Md : 1950). 1998;161(7):3557-68.

33. Zaragoza $\mathrm{O}$, Casadevall A. Antibodies produced in response to Cryptococcus neoformans pulmonary infection in mice have characteristics of nonprotective antibodies. Infection and Immunity. 2004;72(7):4271-4.

34. Dam TK, Torres M, Brewer CF, Casadevall A. Isothermal titration calorimetry reveals differential binding thermodynamics of variable region-identical antibodies differing in constant region for a univalent ligand. The Journal of biological chemistry. 2008;283(46):31366-70.

35. Casadevall A, Pirofski LA. A new synthesis for antibody-mediated immunity. Nature immunology. 2012;13(1):21-8.

36. Belay T, Cherniak R, O'Neill EB, Kozel TR. Serotyping of Cryptococcus neoformans by dot enzyme assay. Journal of Clinical Microbiology. 1996;34(2):466-70.

37. Litvintseva AP, Thakur R, Vilgalys R, Mitchell TG. Multilocus sequence typing reveals three genetic subpopulations of Cryptococcus neoformans var. grubii (serotype $A$ ), including a unique population in Botswana. Genetics. 2006;172(4):2223-38. 
38. Meyer W, Marszewska K, Amirmostofian M, Igreja RP, Hardtke C, Methling K, et al. Molecular typing of global isolates of Cryptococcus neoformans var. neoformans by polymerase chain reaction fingerprinting and randomly amplified polymorphic DNA-a pilot study to standardize techniques on which to base a detailed epidemiological survey. Electrophoresis. 1999;20(8):1790-9.

39. Trilles WMaL. Genotyping of the Cryptococcus neoformans/C.gattii species complex. Australian Biochemist. 2010;41.

40. Casadevall A PJ. Cryptococcus neoformans. Washington, DC: ASM Press. 1998.

41. Gokulshankar S, Ranganathan S, Ranjith MS, Ranjithsingh AJ. Prevalence, serotypes and mating patterns of Cryptococcus neoformans in the pellets of different avifauna in Madras, India. Mycoses. 2004;47(7):310-4.

42. Barreto de Oliveira MT, Boekhout T, Theelen B, Hagen F, Baroni FA, Lazera MS, et al. Cryptococcus neoformans shows a remarkable genotypic diversity in Brazil. Journal of Clinical Microbiology. 2004;42(3):1356-9.

43. Casali AK, Goulart L, Rosa e Silva LK, Ribeiro AM, Amaral AA, Alves SH, et al. Molecular typing of clinical and environmental Cryptococcus neoformans isolates in the Brazilian state Rio Grande do Sul. FEMS yeast research. 2003;3(4):405-15.

44. Nishikawa MM, Lazera MS, Barbosa GG, Trilles L, Balassiano BR, Macedo RC, et al. Serotyping of 467 Cryptococcus neoformans isolates from clinical and environmental sources in Brazil: analysis of host and regional patterns. Journal of Clinical Microbiology. 2003;41(1):73-7.

45. Filiu WF, Wanke B, Aguena SM, Vilela VO, Macedo RC, Lazera M. Avian habitats as sources of Cryptococcus neoformans in the city of Campo Grande, Mato Grosso do Sul, Brazil. Revista da Sociedade Brasileira de Medicina Tropical. 2002;35(6):591-5.

46. Pal M, Onda C, Hasegawa A. Isolation of saprophytic Cryptococcus neoformans. Nihon juigaku zasshi The Japanese journal of veterinary science. 1990;52(6):1171-4.

47. Kronstad JW, Attarian R, Cadieux B, Choi J, D'Souza CA, Griffiths EJ, et al. Expanding fungal pathogenesis: Cryptococcus breaks out of the opportunistic box. Nat Rev Microbiol. 2011;9(3):193203.

48. Coelho C, Bocca AL, Casadevall A. The intracellular life of Cryptococcus neoformans. Annu Rev Pathol. 2014;9:219-38.

49. Velagapudi R, Hsueh YP, Geunes-Boyer S, Wright JR, Heitman J. Spores as infectious propagules of Cryptococcus neoformans. Infection and Immunity. 2009;77(10):4345-55.

50. Giles SS, Dagenais TR, Botts MR, Keller NP, Hull CM. Elucidating the pathogenesis of spores from the human fungal pathogen Cryptococcus neoformans. Infection and Immunity. 2009;77(8):3491-500.

51. Chang YC, Stins MF, McCaffery MJ, Miller GF, Pare DR, Dam T, et al. Cryptococcal yeast cells invade the central nervous system via transcellular penetration of the blood-brain barrier. Infection and Immunity. 2004;72(9):4985-95.

52. Liu H, Cottrell TR, Pierini LM, Goldman WE, Doering TL. RNA interference in the pathogenic fungus Cryptococcus neoformans. Genetics. 2002;160(2):463-70.

53. Murphy JW. Protective cell-mediated immunity against Cryptococcus neoformans. Research in immunology. 1998;149(4-5):373-86; discussion 519-22.

54. Huffnagle GB, Lipscomb MF. Cells and cytokines in pulmonary cryptococcosis. Research in immunology. 1998;149(4-5):387-96; discussion 512-4.

55. Tucker SC, Casadevall A. Replication of Cryptococcus neoformans in macrophages is accompanied by phagosomal permeabilization and accumulation of vesicles containing polysaccharide in the cytoplasm. Proceedings of the National Academy of Sciences of the United States of America. 2002;99(5):3165-70.

56. Garcia-Hermoso D, Janbon G, Dromer F. Epidemiological evidence for dormant Cryptococcus neoformans infection. Journal of Clinical Microbiology. 1999;37(10):3204-9.

57. Santangelo R, Zoellner H, Sorrell T, Wilson C, Donald C, Djordjevic J, et al. Role of extracellular phospholipases and mononuclear phagocytes in dissemination of cryptococcosis in a murine model. Infection and Immunity. 2004;72(4):2229-39. 
58. Chretien F, Lortholary O, Kansau I, Neuville S, Gray F, Dromer F. Pathogenesis of cerebral Cryptococcus neoformans infection after fungemia. The Journal of infectious diseases. 2002;186(4):522-30.

59. Olszewski MA, Noverr MC, Chen GH, Toews GB, Cox GM, Perfect JR, et al. Urease expression by Cryptococcus neoformans promotes microvascular sequestration, thereby enhancing central nervous system invasion. The American journal of pathology. 2004;164(5):1761-71.

60. Alvarez $M$, Casadevall A. Phagosome extrusion and host-cell survival after Cryptococcus neoformans phagocytosis by macrophages. Current biology : CB. 2006;16(21):2161-5.

61. Ma H, Croudace JE, Lammas DA, May RC. Direct cell-to-cell spread of a pathogenic yeast. BMC immunology. 2007;8:15.

62. Ma H, Croudace JE, Lammas DA, May RC. Expulsion of live pathogenic yeast by macrophages. Current biology : CB. 2006;16(21):2156-60.

63. Alvarez $M$, Casadevall A. Cell-to-cell spread and massive vacuole formation after Cryptococcus neoformans infection of murine macrophages. BMC immunology. 2007;8:16.

64. Pappalardo MC, Melhem MS. Cryptococcosis: a review of the Brazilian experience for the disease. Rev Inst Med Trop Sao Paulo. 2003;45(6):299-305.

65. Pyrgos V, Seitz AE, Steiner CA, Prevots DR, Williamson PR. Epidemiology of cryptococcal meningitis in the US: 1997-2009. PLoS One. 2013;8(2):e56269.

66. Perfect JR, Dismukes WE, Dromer F, Goldman DL, Graybill JR, Hamill RJ, et al. Clinical practice guidelines for the management of cryptococcal disease: 2010 update by the infectious diseases society of america. Clin Infect Dis. 2010;50(3):291-322.

67. Doering TL. How Sweet it is! Cell Wall Biogenesis and Polysaccharide Capsule Formation in Cryptococcus neoformans. Annual review of microbiology. 2009;63:223-47.

68. Casadevall A, Nosanchuk JD, Williamson P, Rodrigues ML. Vesicular transport across the fungal cell wall. Trends in microbiology. 2009;17(4):158-62.

69. Yoneda A, Doering TL. A eukaryotic capsular polysaccharide is synthesized intracellularly and secreted via exocytosis. Mol Biol Cell. 2006;17(12):5131-40.

70. Eisenman HC, Frases S, Nicola AM, Rodrigues ML, Casadevall A. Vesicle-associated melanization in Cryptococcus neoformans. Microbiology (Reading, England). 2009;155(Pt 12):3860-7.

71. Siafakas AR, Sorrell TC, Wright LC, Wilson C, Larsen M, Boadle R, et al. Cell wall-linked cryptococcal phospholipase $\mathrm{B} 1$ is a source of secreted enzyme and a determinant of cell wall integrity. The Journal of biological chemistry. 2007;282(52):37508-14.

72. Cox GM, Mukherjee J, Cole GT, Casadevall A, Perfect JR. Urease as a virulence factor in experimental cryptococcosis. Infection and Immunity. 2000;68(2):443-8.

73. Del Poeta M. Role of Phagocytosis in the Virulence of Cryptococcus neoformans. Eukaryotic cell. 2004;3(5):1067-75.

74. McFadden D, Zaragoza O, Casadevall A. The capsular dynamics of Cryptococcus neoformans. Trends in microbiology. 2006;14(11):497-505.

75. Collins HL, Bancroft GJ. Encapsulation of Cryptococcus neoformans impairs antigen-specific Tcell responses. Infection and Immunity. 1991;59(11):3883-8.

76. Zaragoza O, Rodrigues ML, De Jesus M, Frases S, Dadachova E, Casadevall A. The capsule of the fungal pathogen Cryptococcus neoformans. Advances in applied microbiology. 2009;68:133-216.

77. Heitman J K, TR, Kwon-Chung KJ, Perfect JR, Casadevall A. . Cryptococcus from human pathogen to model yeast. press A, editor: ASM press; 2011.

78. Monari C, Paganelli F, Bistoni F, Kozel TR, Vecchiarelli A. Capsular polysaccharide induction of apoptosis by intrinsic and extrinsic mechanisms. Cellular microbiology. 2008;10(10):2129-37.

79. Dong ZM, Murphy JW. Intravascular cryptococcal culture filtrate (CneF) and its major component, glucuronoxylomannan, are potent inhibitors of leukocyte accumulation. Infection and Immunity. 1995;63(3):770-8.

80. Kozel TR, Gotschlich EC. The capsule of cryptococcus neoformans passively inhibits phagocytosis of the yeast by macrophages. Journal of immunology (Baltimore, Md : 1950). 1982;129(4):1675-80. 
81. Yuan RR, Spira G, Oh J, Paizi M, Casadevall A, Scharff MD. Isotype switching increases efficacy of antibody protection against Cryptococcus neoformans infection in mice. Infection and Immunity. 1998;66(3):1057-62.

82. Steenbergen JN, Shuman HA, Casadevall A. Cryptococcus neoformans interactions with amoebae suggest an explanation for its virulence and intracellular pathogenic strategy in macrophages. Proceedings of the National Academy of Sciences of the United States of America. 2001;98(26):15245-50.

83. Bose I, Reese AJ, Ory JJ, Janbon G, Doering TL. A yeast under cover: the capsule of Cryptococcus neoformans. Eukaryotic cell. 2003;2(4):655-63.

84. Cherniak R, Jones RG, Reiss E. Structure determination of Cryptococcus neoformans serotype A-variant glucuronoxylomannan by 13C-n.m.r. spectroscopy. Carbohydrate research. 1988;172(1):113-38.

85. Cherniak R, Sundstrom JB. Polysaccharide antigens of the capsule of Cryptococcus neoformans. Infection and Immunity. 1994;62(5):1507-12.

86. Cherniak R, Valafar H, Morris LC, Valafar F. Cryptococcus neoformans chemotyping by quantitative analysis of $1 \mathrm{H}$ nuclear magnetic resonance spectra of glucuronoxylomannans with a computer-simulated artificial neural network. Clinical and diagnostic laboratory immunology. 1998;5(2):146-59.

87. McFadden DC, De Jesus M, Casadevall A. The physical properties of the capsular polysaccharides from Cryptococcus neoformans suggest features for capsule construction. The Journal of biological chemistry. 2006;281(4):1868-75.

88. Cherniak R. RR, Turner S. H. A galactoxylomannan antigen of Cryptococcus neoformans serotype A. Carbohydr Res 103:239-250. 1982.

89. Butas CA, Lloyd-Smith DL. Cryptococcal Meningitis: Treatment with Amphotericin B. Canadian Medical Association Journal. 1962;87(11):588-91.

90. Vermes A, Guchelaar HJ, Dankert J. Flucytosine: a review of its pharmacology, clinical indications, pharmacokinetics, toxicity and drug interactions. The Journal of antimicrobial chemotherapy. 2000;46(2):171-9.

91. Sanglard D, Coste A, Ferrari S. Antifungal drug resistance mechanisms in fungal pathogens from the perspective of transcriptional gene regulation. FEMS yeast research. 2009;9(7):1029-50.

92. Jarvis JN, Dromer F, Harrison TS, Lortholary O. Managing cryptococcosis in the immunocompromised host. Current opinion in infectious diseases. 2008;21(6):596-603.

93. Sloan D, Dlamini S, Paul N, Dedicoat M. Treatment of acute cryptococcal meningitis in HIV infected adults, with an emphasis on resource-limited settings. The Cochrane database of systematic reviews. 2008(4):Cd005647.

94. Catalan M, Montejo JC. Systemic antifungals. Pharmacodynamics and pharmacokinetics. Revista iberoamericana de micologia. 2006;23(1):39-49.

95. Polak A, Scholer HJ. Mode of action of 5-fluorocytosine and mechanisms of resistance. Chemotherapy. 1975;21(3-4):113-30.

96. Vermes A, van Der Sijs H, Guchelaar HJ. Flucytosine: correlation between toxicity and pharmacokinetic parameters. Chemotherapy. 2000;46(2):86-94.

97. Kauffman CA, Frame PT. Bone Marrow Toxicity Associated with 5-Fluorocytosine Therapy. Antimicrobial Agents and Chemotherapy. 1977;11(2):244-7.

98. Xie JL, Polvi EJ, Shekhar-Guturja T, Cowen LE. Elucidating drug resistance in human fungal pathogens. Future microbiology. 2014;9(4):523-42.

99. Kathiravan MK, Salake AB, Chothe AS, Dudhe PB, Watode RP, Mukta MS, et al. The biology and chemistry of antifungal agents: a review. Bioorganic \& medicinal chemistry. 2012;20(19):567898.

100. Ghannoum MaP, JR. . Pharmacology of Azole Antifungal Agents. In: Perfect MAGaJR, editor. Antifungal Therapy: CRC Press; 2009. p. 488.

101. Dixon DM WT. Antifungal Agents. In: S B, editor. Medical Microbiology. 4th edition. University of Texas Medical Branch at Galveston1996. 
102. Hall GS. Interactions of Yeasts, Moulds, and Antifungal Agents: How to Detect Resistance. Media SSB, editor2011.

103. Rajasingham R, Rolfes MA, Birkenkamp KE, Meya DB, Boulware DR. Cryptococcal meningitis treatment strategies in resource-limited settings: a cost-effectiveness analysis. PLoS Med. 2012;9(9):e1001316.

104. Ghannoum MAaP, J. R. . Antifungal Therapy. New York, USA: Informa healthcare; 2010. p. 308-19.

105. Cutler JE, Deepe GS, Klein BS. Advances in combating fungal diseases: vaccines on the threshold. Nature reviews Microbiology. 2007;5(1):13-28.

106. Deepe GS, Jr. Preventative and therapeutic vaccines for fungal infections: from concept to implementation. Expert review of vaccines. 2004;3(6):701-9.

107. Baronetti JL, Chiapello LS, Aoki MP, Gea S, Masih DT. Heat killed cells of Cryptococcus neoformans var. grubii induces protective immunity in rats: immunological and histopathological parameters. Medical mycology. 2006;44(6):493-504.

108. Vecchiarelli A. Immunoregulation by capsular components of Cryptococcus neoformans. Medical mycology. 2000;38(6):407-17.

109. Chen LC, Goldman DL, Doering TL, Pirofski L, Casadevall A. Antibody response to Cryptococcus neoformans proteins in rodents and humans. Infection and Immunity. 1999;67(5):2218-24.

110. Goldman DL, Khine H, Abadi J, Lindenberg DJ, Pirofski L, Niang R, et al. Serologic evidence for Cryptococcus neoformans infection in early childhood. Pediatrics. 2001;107(5):E66.

111. Rodrigues ML, Travassos LR, Miranda KR, Franzen AJ, Rozental S, de Souza W, et al. Human antibodies against a purified glucosylceramide from Cryptococcus neoformans inhibit cell budding and fungal growth. Infection and Immunity. 2000;68(12):7049-60.

112. Rosas Á L, Nosanchuk JD, Casadevall A. Passive Immunization with Melanin-Binding Monoclonal Antibodies Prolongs Survival of Mice with Lethal Cryptococcus neoformans Infection. Infection and Immunity. 2001;69(5):3410-2.

113. Casadevall A, DeShaw M, Fan M, Dromer F, Kozel TR, Pirofski LA. Molecular and idiotypic analysis of antibodies to Cryptococcus neoformans glucuronoxylomannan. Infection and Immunity. 1994;62(9):3864-72.

114. Kozel TR, Gulley WF, Cazin J. Immune response to Cryptococcus neoformans soluble polysaccharide: immunological unresponsiveness. Infection and Immunity. 1977;18(3):701-7.

115. Devi SJ, Schneerson R, Egan W, Ulrich TJ, Bryla D, Robbins JB, et al. Cryptococcus neoformans serotype A glucuronoxylomannan-protein conjugate vaccines: synthesis, characterization, and immunogenicity. Infection and Immunity. 1991;59(10):3700-7.

116. Devi SJ. Preclinical efficacy of a glucuronoxylomannan-tetanus toxoid conjugate vaccine of Cryptococcus neoformans in a murine model. Vaccine. 1996;14(9):841-4.

117. Vukovic P, Hogarth PM, Barnes N, Kaslow DC, Good MF. Immunoglobulin G3 antibodies specific for the 19-kilodalton carboxyl-terminal fragment of Plasmodium yoelii merozoite surface protein 1 transfer protection to mice deficient in Fc-gammaRI receptors. Infection and Immunity. 2000;68(5):3019-22.

118. Kakeya H, Udono H, Ikuno N, Yamamoto Y, Mitsutake K, Miyazaki T, et al. A 77-kilodalton protein of Cryptococcus neoformans, a member of the heat shock protein 70 family, is a major antigen detected in the sera of mice with pulmonary cryptococcosis. Infection and Immunity. 1997;65(5):1653-8.

119. Murphy JW. Influence of cryptococcal antigens on cell-mediated immunity. Reviews of infectious diseases. 1988;10 Suppl 2:S432-5.

120. Murphy JW, Mosley RL, Cherniak R, Reyes GH, Kozel TR, Reiss E. Serological, electrophoretic, and biological properties of Cryptococcus neoformans antigens. Infection and Immunity. 1988;56(2):424-31.

121. Orendi JM, Verheul AF, De Vos NM, Visser MR, Snippe H, Cherniak R, et al. Mannoproteins of Cryptococcus neoformans induce proliferative response in human peripheral blood mononuclear 
cells (PBMC) and enhance HIV-1 replication. Clinical and Experimental Immunology. 1997;107(2):2939.

122. Pitzurra L, Perito S, Baldelli F, Bistoni F, Vecchiarelli A. Humoral response against Cryptococcus neoformans mannoprotein antigens in HIV-infected patients. Clinical and Experimental Immunology. 2003;133(1):91-6.

123. Singh N, Lortholary O, Alexander BD, Gupta KL, John GT, Pursell K, et al. An immune reconstitution syndrome-like illness associated with Cryptococcus neoformans infection in organ transplant recipients. Clinical infectious diseases : an official publication of the Infectious Diseases Society of America. 2005;40(12):1756-61.

124. Bonham S, Meya DB, Bohjanen PR, Boulware DR. Biomarkers of HIV Immune Reconstitution Inflammatory Syndrome. Biomarkers in medicine. 2008;2(4):349-61.

125. Casadevall A, Cleare W, Feldmesser M, Glatman-Freedman A, Goldman DL, Kozel TR, et al. Characterization of a Murine Monoclonal Antibody to Cryptococcus neoformans Polysaccharide That Is a Candidate for Human Therapeutic Studies. Antimicrobial Agents and Chemotherapy. 1998;42(6):1437-46.

126. Pirofski L, Lui R, DeShaw $M$, Kressel $A B$, Zhong Z. Analysis of human monoclonal antibodies elicited by vaccination with a Cryptococcus neoformans glucuronoxylomannan capsular polysaccharide vaccine. Infection and Immunity. 1995;63(8):3005-14.

127. Elluru SR, Kaveri SV, Bayry J. The protective role of immunoglobulins in fungal infections and inflammation. Seminars in immunopathology. 2015;37(2):187-97.

128. Casadevall A, Pirofski LA. Antibody-mediated protection through cross-reactivity introduces a fungal heresy into immunological dogma. Infection and Immunity. 2007;75(11):5074-8.

129. Casadevall A, Pirofski LA. A reappraisal of humoral immunity based on mechanisms of antibody-mediated protection against intracellular pathogens. Advances in immunology. 2006;91:144.

130. Casadevall A, Pirofski LA. Immunoglobulins in defense, pathogenesis, and therapy of fungal diseases. Cell host \& microbe. 2012;11(5):447-56.

131. Eckert TF, Kozel TR. Production and characterization of monoclonal antibodies specific for Cryptococcus neoformans capsular polysaccharide. Infection and Immunity. 1987;55(8):1895-9.

132. Dromer F, Charreire J, Contrepois A, Carbon C, Yeni P. Protection of mice against experimental cryptococcosis by anti-Cryptococcus neoformans monoclonal antibody. Infection and Immunity. 1987;55(3):749-52.

133. Casadevall A, Scharff MD. The mouse antibody response to infection with Cryptococcus neoformans: $\mathrm{VH}$ and $\mathrm{VL}$ usage in polysaccharide binding antibodies. The Journal of Experimental Medicine. 1991;174(1):151-60.

134. Mukherjee J, Casadevall A, Scharff MD. Molecular characterization of the humoral responses to Cryptococcus neoformans infection and glucuronoxylomannan-tetanus toxoid conjugate immunization. The Journal of Experimental Medicine. 1993;177(4):1105-16.

135. Nakouzi A, Valadon P, Nosanchuk J, Green N, Casadevall A. Molecular Basis for Immunoglobulin M Specificity to Epitopes in Cryptococcus neoformans Polysaccharide That Elicit Protective and Nonprotective Antibodies. Infection and Immunity. 2001;69(5):3398-409.

136. Young AC, Valadon P, Casadevall A, Scharff MD, Sacchettini JC. The three-dimensional structures of a polysaccharide binding antibody to Cryptococcus neoformans and its complex with a peptide from a phage display library: implications for the identification of peptide mimotopes. J Mol Biol. 1997;274(4):622-34.

137. Eryilmaz E, Janda A, Kim J, Cordero RJB, Cowburn D, Casadevall A. Global structures of IgG isotypes expressing identical variable regions. Molecular immunology. 2013;56(4).

138. Zebedee SL, Koduri RK, Mukherjee J, Mukherjee S, Lee S, Sauer DF, et al. Mouse-human immunoglobulin G1 chimeric antibodies with activities against Cryptococcus neoformans. Antimicrobial Agents and Chemotherapy. 1994;38(7):1507-14. 
139. Leturcq DJ, Moriarty AM, Talbott G, Winn RK, Martin TR, Ulevitch RJ. Antibodies against CD14 protect primates from endotoxin-induced shock. The Journal of clinical investigation. 1996;98(7):1533-8.

140. Schroeder HW, Cavacini L. Structure and Function of Immunoglobulins. The Journal of allergy and clinical immunology. 2010;125(2 0 2):S41-52.

141. Casadevall A, Janda A. Immunoglobulin isotype influences affinity and specificity. Proceedings of the National Academy of Sciences of the United States of America. 2012;109(31):12272-3.

142. Torres M, Fernandez-Fuentes N, Fiser A, Casadevall A. The immunoglobulin heavy chain constant region affects kinetic and thermodynamic parameters of antibody variable region interactions with antigen. The Journal of biological chemistry. 2007;282(18):13917-27.

143. Lieber M. Antibody diversity: a link between switching and hypermutation. Current biology : CB. 2000;10(21):R798-800.

144. Li Z, Woo CJ, Iglesias-Ussel MD, Ronai D, Scharff MD. The generation of antibody diversity through somatic hypermutation and class switch recombination. Genes \& development. 2004;18(1):1-11.

145. Torres M, May R, Scharff MD, Casadevall A. Variable-region-identical antibodies differing in isotype demonstrate differences in fine specificity and idiotype. Journal of immunology (Baltimore, Md : 1950). 2005;174(4):2132-42.

146. Cooper L, Shikhman AR, Glass DD, Kangisser D, Cunningham MW, Greenspan NS. Role of heavy chain constant domains in antibody-antigen interaction. Apparent specificity differences among streptococcal IgG antibodies expressing identical variable domains. Journal of immunology (Baltimore, Md : 1950). 1993;150(6):2231-42.

147. Beck A, Wurch T, Bailly C, Corvaia N. Strategies and challenges for the next generation of therapeutic antibodies. Nature reviews Immunology. 2010;10(5):345-52.

148. Ravetch JV, Kinet JP. Fc receptors. Annual review of immunology. 1991;9:457-92.

149. Tudor D, Yu H, Maupetit J, Drillet AS, Bouceba T, Schwartz-Cornil I, et al. Isotype modulates epitope specificity, affinity, and antiviral activities of anti-HIV-1 human broadly neutralizing 2F5 antibody. Proceedings of the National Academy of Sciences of the United States of America. 2012;109(31):12680-5.

150. McLean GR, Torres M, Elguezabal N, Nakouzi A, Casadevall A. Isotype can affect the fine specificity of an antibody for a polysaccharide antigen. Journal of immunology (Baltimore, Md : 1950). 2002;169(3):1379-86.

151. Diamond DE. A new Fc receptor on mouse macrophages binding IgG3. The Journal of Experimental Medicine. 1981;153(3):514-9.

152. Gavin AL, Barnes N, Dijstelbloem HM, Hogarth PM. Identification of the mouse IgG3 receptor: implications for antibody effector function at the interface between innate and adaptive immunity. Journal of immunology (Baltimore, Md : 1950). 1998;160(1):20-3.

153. Saylor CA, Dadachova E, Casadevall A. Murine IgG1 and IgG3 isotype switch variants promote phagocytosis of Cryptococcus neoformans through different receptors. Journal of immunology (Baltimore, Md : 1950). 2010;184(1):336-43.

154. Yuan R, Casadevall A, Spira G, Scharff MD. Isotype switching from IgG3 to IgG1 converts a nonprotective murine antibody to Cryptococcus neoformans into a protective antibody. Journal of immunology (Baltimore, Md : 1950). 1995;154(4):1810-6.

155. Mukherjee J NG, Scharff MD and Casadeval A. . Protective and nonprotective monoclonal antibodies to Cryptococcus neoformans originating from one B cell. The Journal of Experimental Medicine. 1995;181(1):405-9.

156. Janin J. Principles of protein-protein recognition from structure to thermodynamics. Biochimie. 1995;77(7-8):497-505.

157. Kato K, Matsunaga C, Odaka A, Yamato S, Takaha W, Shimada I, et al. Carbon-13 NMR study of switch variant anti-dansyl antibodies: antigen binding and domain-domain interactions. Biochemistry. 1991;30(26):6604-10. 
158. Janda A, Eryilmaz E, Nakouzi A, Pohl MA, Bowen A, Casadevall A. Variable Region Identical IgA and IgE to Cryptococcus neoformans Capsular Polysaccharide Manifest Specificity Differences. The Journal of biological chemistry. 2015;290(19):12090-100.

159. Janda A BA, Greenspan NS and Casadevall A. . Ig Constant Region Effects on Variable Region Structure and Function. Front Microbiol. 2016.

160. Janda A, Eryilmaz E, Nakouzi A, Cowburn D, Casadevall A. Variable Region Identical Immunoglobulins Differing in Isotype Express Different Paratopes. The Journal of biological chemistry. 2012;287(42):35409-17.

161. Barnes N, Gavin AL, Tan PS, Mottram P, Koentgen F, Hogarth PM. FcgammaRI-deficient mice show multiple alterations to inflammatory and immune responses. Immunity. 2002;16(3):379-89.

162. Hjelm F, Carlsson F, Verbeek S, Heyman B. IgG3-mediated enhancement of the antibody response is normal in Fc gammaRI-deficient mice. Scand J Immunol. 2005;62(5):453-61.

163. Gibson AL, Herron JN, He XM, Patrick VA, Mason ML, Lin JN, et al. Differences in crystal properties and ligand affinities of an antifluorescyl Fab (4-4-20) in two solvent systems. Proteins. 1988;3(3):155-60.

164. Herron JN, He XM, Mason ML, Voss EW, Jr., Edmundson AB. Three-dimensional structure of a fluorescein-Fab complex crystallized in 2-methyl-2,4-pentanediol. Proteins. 1989;5(4):271-80.

165. Bedzyk WD, Johnson LS, Riordan GS, Voss EW, Jr. Comparison of variable region primary structures within an anti-fluorescein idiotype family. The Journal of biological chemistry. 1989;264(3):1565-9.

166. Whitlow M, Howard AJ, Wood JF, Voss EW, Jr., Hardman KD. 1.85 A structure of antifluorescein 4-4-20 Fab. Protein engineering. 1995;8(8):749-61.

167. Sambrook J, Fritsch EF, Maniatis T. Molecular Cloning: A Laboratory Manual. . 3a ed. ed. New York, USA: Cold Spring Harbor Laboratory Press; 2001.

168. BIO-SCIENCES GHU-SGECI--A. HiScreen Capto DEAE. Available from: https://www.gelifesciences.com/gehcls images/GELS/Related\%20Content/Files/1335426794335/litd oc28933962 20120426102532.pdf.

169. BIO-SCIENCES GHU-SGECI--A. HiLoad 16/600 and 26/600 Superdex 75 prep grade. Available from:

https://www.gelifesciences.com/gehcls images/GELS/Related\%20Content/Files/1326706518989/litd oc28992017 20120420132119.pdf.

170. Bio-Rad L. A guide to polyacrylamide gel electrophoresis and detection: Bio-Rad Laboratories; 2013. Available from: http://www.bio-rad.com/webroot/web/pdf//sr/literature/Bulletin 6040.pdf.

171. Chevallet M. Silver staining of proteins in polyacrylamide gels. 2006;1(4):1852-8.

172. Nicola AM. Estudos de fatores associados a virulência e imunidade na interação entre macrófagos e Cryptococcus neoformans: Universidade de Brasília; 2011.

173. Miksa M, Komura H, Wu R, Shah KG, Wang P. A novel method to determine the engulfment of apoptotic cells by macrophages using pHrodo succinimidyl ester. J Immunol Methods. 2009;342(12):71-7.

174. Togawa R, Brigido M. PHPH - Análise de cromatogramas: Electropherogram quality analysis. Available from: http://www.biomol.unb.br/phph/index.html.

175. Lipman DJ, Wilbur WJ, Smith TF, Waterman MS. On the statistical significance of nucleic acid similarities. Nucleic Acids Res. 1984;12(1 Pt 1):215-26.

176. Fitch WM. Random sequences. Journal of molecular biology. 1983;163(2):171-6.

177. NCBI. The Statistics of Sequence Similarity Scores. Available from: http://www.ncbi.nlm.nih.gov/BLAST/tutorial/Altschul-1.html.

178. Geisse S, Voedisch B. Transient expression technologies: past, present, and future. Methods in molecular biology (Clifton, NJ). 2012;899:203-19.

179. Jostock T, Knopf HP. Mammalian stable expression of biotherapeutics. Methods in molecular biology (Clifton, NJ). 2012;899:227-38.

180. Roland E. Kontermann SD. Antibody Engineering. Springer. 2010;2. 
181. Townsend-Nicholson A. Approaches to the stable transfection of $G$ protein-coupled receptors. Methods in molecular biology (Clifton, NJ). 1997;83:45-54.

182. Voynov V, Caravella J. Methods Mol Biol. Therapeutic Proteins Humana press; 2012.

183. j.King D. Applications and Engineering of Monoclonal Antibodies. CRC Press. 1998.

184. Birch JR, Racher AJ. Antibody production. Advanced drug delivery reviews. 2006;58(5-6):671-

85.

185. Baldi L, Hacker DL, Adam M, Wurm FM. Recombinant protein production by large-scale transient gene expression in mammalian cells: state of the art and future perspectives. Biotechnology letters. 2007;29(5):677-84.

186. Gstraunthaler G. Alternatives to the use of fetal bovine serum: serum-free cell culture. Altex. 2003;20(4):275-81.

187. Yee JC. Genomic and Proteomic Profiling of Mammalian Cells Under High Productivity States: University of Minnesota; 2008.

188. Ye J, Alvin K, Latif $\mathrm{H}$, Hsu A, Parikh V, Whitmer T, et al. Rapid protein production using $\mathrm{CHO}$ stable transfection pools. Biotechnology progress. 2010;26(5):1431-7.

189. Abdelmoula M, Spertini F, Shibata T, Gyotoku Y, Luzuy S, Lambert PH, et al. IgG3 is the major source of cryoglobulins in mice. Journal of immunology (Baltimore, Md : 1950). 1989;143(2):526-32.

190. Butler M, Meneses-Acosta A. Recent advances in technology supporting biopharmaceutical production from mammalian cells. Applied microbiology and biotechnology. 2012;96(4):885-94.

191. Biontex. K2 ${ }^{\circledR}$ Transfection System: Manual EN 201601131402 Available from: http://www.biontex.com/con 46 4/cms/upload/pdf/Manual K2-Transfektions-Kit en.pdf.

192. xxM. IF--rU. Mechanism of cationic lipid-mediated transfection. Available from: http://www.thermofisher.com/content/dam/LifeTech/migration/en/filelibrary/pdf.par.75261.file.da t/f063727-mechcationic.pdf.

193. Junquera E, Aicart E. Cationic lipids as transfecting agents of DNA in gene therapy. Current topics in medicinal chemistry. 2014;14(5):649-63.

194. GHU-SGECl B-S. HiTrap ${ }^{\mathrm{TM}}$ Protein G HP. Available from: https://www.gelifesciences.com/gehcls images/GELS/Related\%20Content/Files/1314716762536/litd oc71700100 20150223004125.pdf.

195. Karen Zhu and William Strong B-RL, Inc.,. Experion ${ }^{\text {TM }}$ Automated Electrophoresis System and the Experion Pro260 Analysis Kit: Accurate and Reproducible Protein Sizing and Quantitation in the Presence of High Salt Concentrations 2006. Available from: http://www.biorad.com/webroot/web/pdf/lsr/literature/Bulletin 5328A.pdf.

196. Carlos D. García KYC-T, Emanuel Carrilho. Capillary Electrophoresis and Microchip Capillary Electrophoresis: Principles, Applications, and Limitations. John Wiley \& Sons. 2013.

197. Kozel TR, Pfrommer GS, Guerlain AS, Highison BA, Highison GJ. Role of the capsule in phagocytosis of Cryptococcus neoformans. Reviews of infectious diseases. 1988;10 Suppl 2:S436-9.

198. Kozel TR. Opsonization and phagocytosis of Cryptococcus neoformans. Archives of medical research. 1993;24(3):211-8.

199. Alvarez M, Saylor C, Casadevall A. Antibody action after phagocytosis promotes Cryptococcus neoformans and Cryptococcus gattii macrophage exocytosis with biofilm-like microcolony formation. Cellular microbiology. 2008;10(8):1622-33.

200. Yuan RR, Clynes R, Oh J, Ravetch JV, Scharff MD. Antibody-mediated Modulation of Cryptococcus neoformans Infection Is Dependent on Distinct Fc Receptor Functions and IgG Subclasses. The Journal of Experimental Medicine. 1998;187(4):641-8.

201. Mansour MK, Levitz SM. Interactions of fungi with phagocytes. Current opinion in microbiology. 2002;5(4):359-65.

202. Mukherjee J, Zuckier LS, Scharff MD, Casadevall A. Therapeutic efficacy of monoclonal antibodies to Cryptococcus neoformans glucuronoxylomannan alone and in combination with amphotericin B. Antimicrobial Agents and Chemotherapy. 1994;38(3):580-7.

203. Antibodies NRCUCoMoPM. Monoclonal Antibody Production: Washington (DC): National Academies Press (US); 1999. 
204. Terada $\mathrm{KHaH}$. Endocytosis of Particle Formulations by Macrophages and Its Application to Clinical Treatment In: InTech, editor.: InTech; 2012.

205. Swanson JA, Watts C. Macropinocytosis. Trends in cell biology. 1995;5(11):424-8.

206. Wright A, Tao MH, Kabat EA, Morrison SL. Antibody variable region glycosylation: position effects on antigen binding and carbohydrate structure. The EMBO Journal. 1991;10(10):2717-23. 